

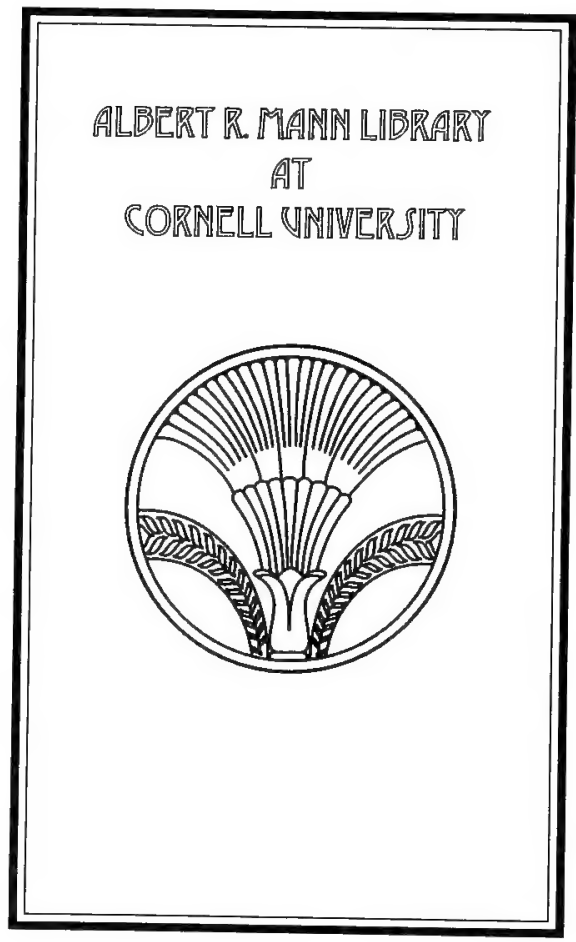


QL 676.P23

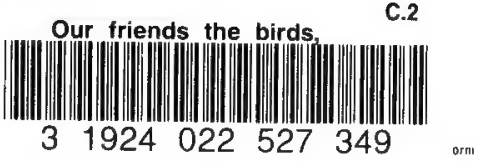




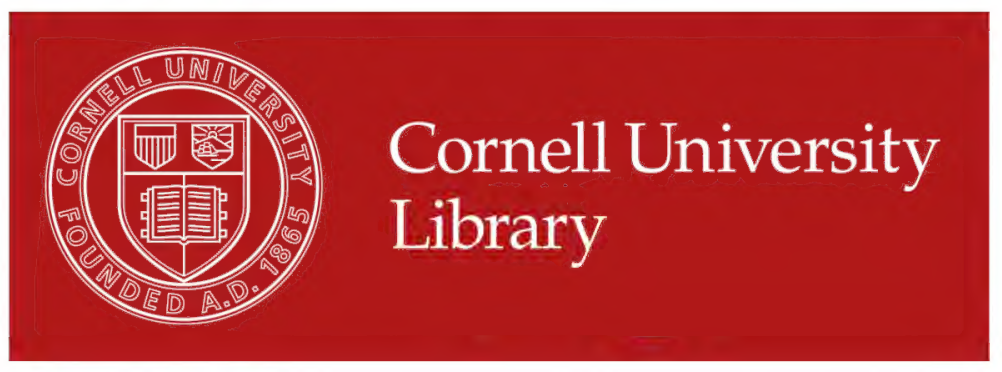

The original of this book is in the Cornell University Library.

There are no known copyright restrictions in the United States on the use of the text.

http://www.archive.org/details/cu31924022527349 


\section{Oar Friends, the Jirds}

\section{BY}

CAROLINE II. PARKFR.

The softly warbled song

Comes through the pleasant woods, and colored wings

Are glancing in the golden sun, along The forest openngs.

-LONGFELLOW.

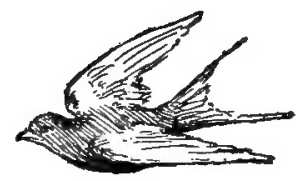

A. FLANAGAN COMPANY

C H I C A G O

h. 
Copyright, I897,

$\mathrm{BY}$

A. Flanagan. 


\author{
TO THE \\ BOYS AND GIRLS \\ $O F$ \\ OUR INTERMEDIATE SCHOOLS \\ THESE, LESSONS \\ ARE \\ Hffectionately Tnscribed \\ HOPING THAT THEY MAY AWAKEN
SUCH AN INTEREST IN OUR
FEATHERED FRIENDS
AS SHALL CAUSE
OUR GIRLS TO CEASE
WEARING ORNAMENTS THAT
ARE A
"SACRIFICE OF BLOOD"
AND OUR BOIS TO LEARN TO
"NAME THE, BIRDS WITHOUT A GUN "
}





\section{PREFACE}

THESE lessons are only an introduction to that most fascinating of nature studies, the study of birds. No attempt has been made to classify them, but a few of our most common birds have been chosen for a series of familiar talks, hoping to awaken, thereby, a desire for further study. There are many writers of delightful bird stories, and for scientific descriptions of birds nothing is more reliable than Dr. Elliott Coues' Key to North American Birds.

By special permission of Dr. Coues, I have used, in an abridged form, descriptions from that book, for Laura's tables.

For the selections of poetry grateful acknowledgements are due the publishers of current periodicals and the works of standard authors.

The poetical selections are suitable for Bird Day or Arbor Day exercises as well as every day work in school.

C. H. P. 


\section{-}




\section{CONTENTS.}

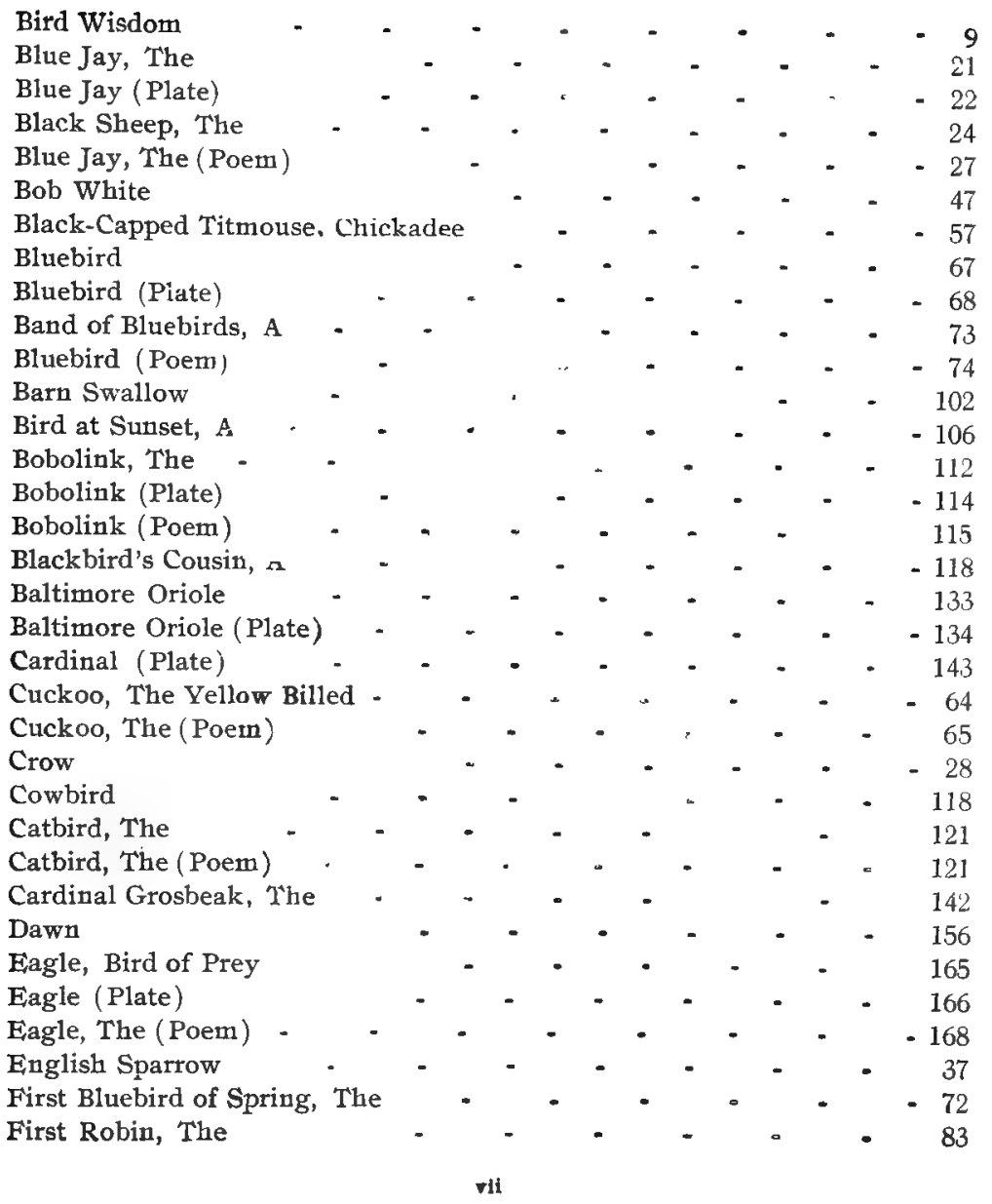


Humming Bird

Humming Bird (Plate)

Humming Bird, The (Poem)

Indigo Bird

Indigo Bird (Plate)

Indigo Bird, The (Poem)

In Summer Time

King Fisher, The (Plate)

King Fisher, The (Poem)

King Fisher, Belted

Kildeer Plover

King Bird, The Bee Martin-

King Bird, The

Little Brother of the Air, A

Migration of Birds

Mourning Dove

Night Birds

Origin of Birds

Oriole, The

Oriole, The (Poem)

Oven Bird, Golden Crowned Thrush

Oven Bird, The (Poem)

"Old Abe"

Pewee

Quail Bob White

Robin, The

Robin (Plate)

Robin, The (Poem)

Red-Winged Blackbird

Red-Winged Blackbird (Plate)

Red Wing, The (Poem)

Rain Song, A

Scarecrow, The (Poem)

Screech Owl

Screech Owl (Plate)

Same Robin

September Robin, A

Snipe, The

Song Sparrow

Song Sparrow, The (Poem)

Sparrows, The 


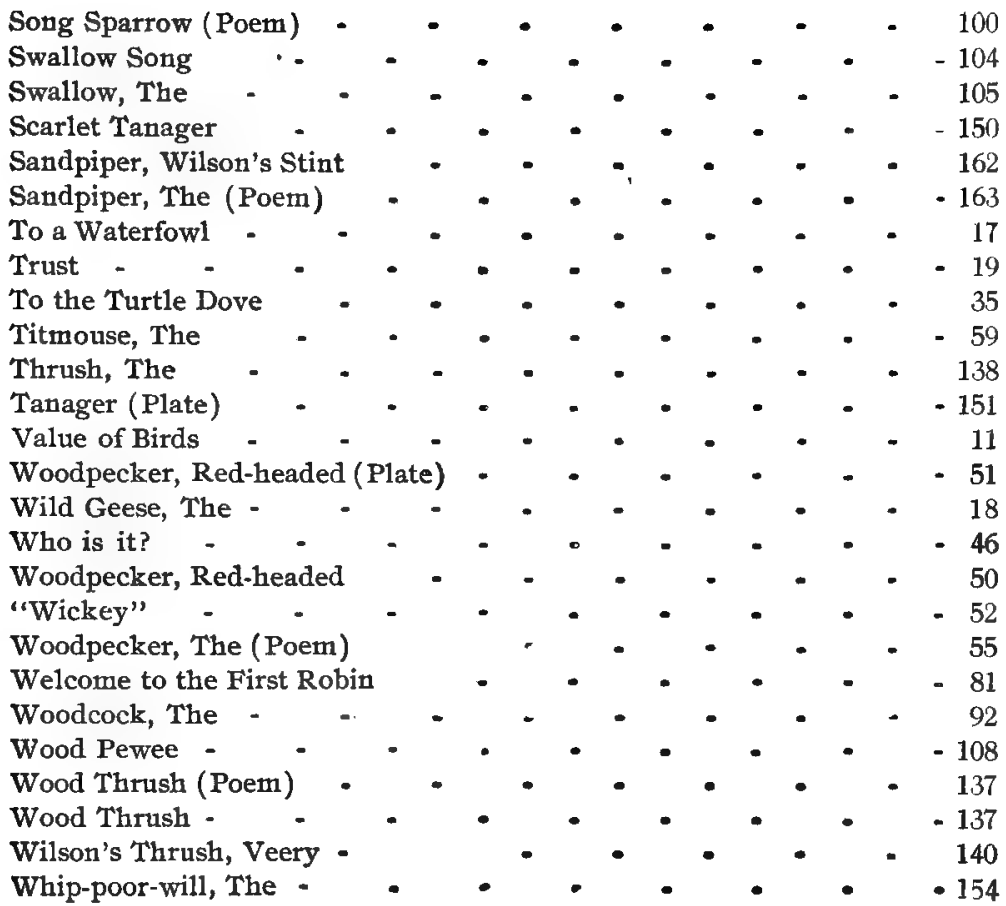

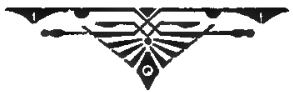





\section{Our Friends, The Birds.}

AURA is a little girl who is so fortunate as (9) to live in a beautiful suburb of a large city, where birds are much more numerous than is usual in a suburban town. From her earliest childhood she noticed the birds as they flitted about in the trees of the large garden where she spent the long bright summer days, and, as she grew older, she would leave her play at any time to listen to a bird's song.

Laura's aunt is a teacher of Greek in a woman's college. One day, when her work had been usually tiresome, she sat down on the window seat in her room and idly watched a little bird as it flew in and out of a tree near by. She became interested in her little neighbor and soon found out its name. She listened to its song and in her daily walks often found others of the same species; then she began to listen for other bird notes, and finally 
spent all of her leisure hours in observing the songs and habits of birds. She always spent the long vacation with Laura and her parents. When Laura was scarcely out of babyhood, her aunt noticed her fondness for birds, and it was not long before Laura was learning a great deal about their habits and homes.

The vacations came and went while Laura was unconsciously spending the summer days in the best kind of a school. Last summer she had just finished her seventh grade work, so her aunt began to introduce her to bird literature. They had many talks together about the "poetry of birds," and her aunt recited to her the beautiful poetic fancy embodied in the verses entitled: 


\section{ORIGIN OF BIRDS.}

THE Indians of the Shasta mountains tell

A legend strange and beautiful;
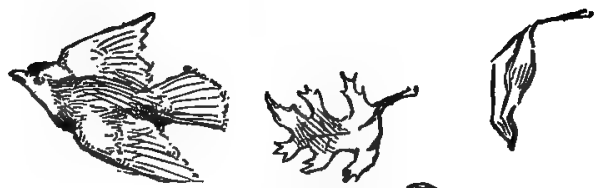

That the Great Spirit stepped from cloud to cloud

In the primeval day,

And first upon the dome of Shasta stood,

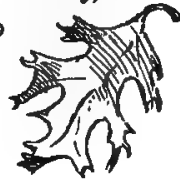

The spotless face of new-born earth to see,

And everywhere he touched the land, up sprung

A green, luxuriant tree.

Pleased with the sight, the splendor of his smile

Melted the snows and made the rivers run,

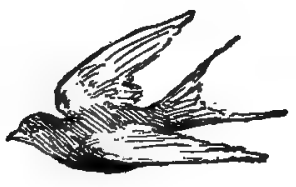

And soon the branches tossed their leafly plumes

And blossomed in the sun.

Day after day, while the first summer shone,

He watched with fresh delight the growing trees;

But Autumn came, and fast the bright leaves fell, Swept by the keener breeze.

Yet were they radiant now, in every hue

Of red and gold which could with sunset vie; Looking on them, $\mathrm{He}$ loved them,- - they were still Too beautiful to die.
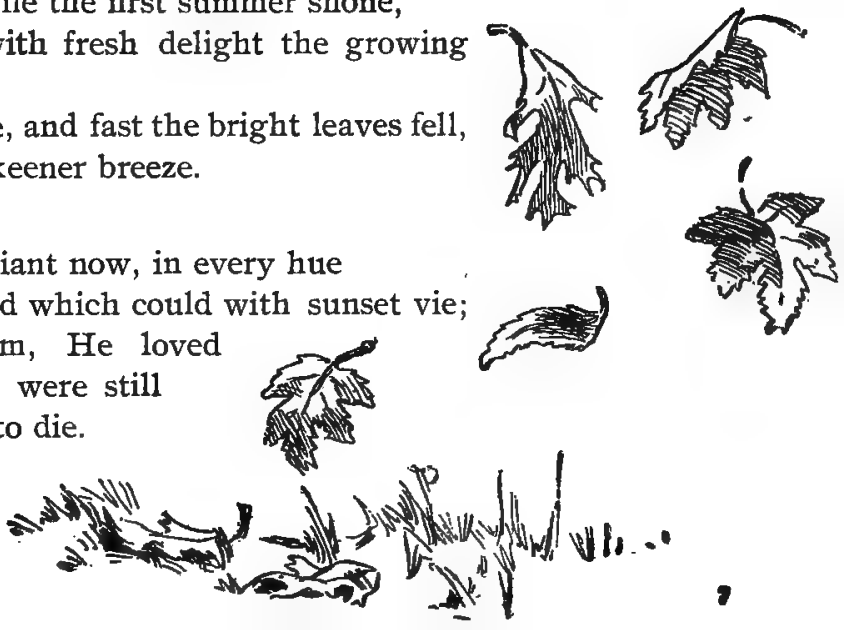
Thrilled by His quickening gaze, each leaf renewed Its life and floated buoyantly along;

Its beauty put forth wings, and as it soared Its gladness grew to song.

Thus from the red-stained oak the robin came, The cardinal birut the maple's splendor bore, The yellow bird the willow's faded gold In living plumage wore.

Even the pale brown leaves the pageant joined, Sparrow and lark awakened to rejoice;

And though they were less fair, He gave to them The more melodious voice.

Since then, the birds close kinship with the trees

Have ever kept, and built the yearly nest Beneath the fragrant shelter of the boughs, As on a mother's breast.

FRANCES LAUGHTON MACR.

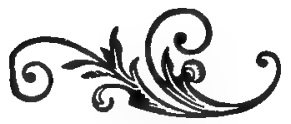

When school opened in the fall, Laura's teacher wanted something for the school to learn and repeat in concert, and Laura told her about Elizabeth Akers' poem- 
Who knows? Though nature teems with mysteries, She never grants us one enlightening word;

The hoariest sage among us and most wise,

Can only wonder with admiring eyes

At the fine wisdom of a little bird.

Surely, these feathered folk, who live so near

To nature, understand her deepest lore.

And, breathing in a purer atmosphere,

Know what the wind says to the leaves, and hear

What the soft ripples whisper to the shore.

Roaming the realms of ether they may know

Truths never touched by our imaginings;

And when they look at tus so far below,

Poor dusty creatures creeping to and fro,

Pity our want of wisdom and of wings.

Miss Sweet, Laura's teacher, was much gratified at the way the children learned and recited this poem, and it gave her a new idea. She was always anxious to interest her pupils, and there were no monotonous recitations in her room, because she always had something practical and pleasant to incite thought and a desire for knowledge. She began by asking Laura to write on "The Value of Birds," as the next topic for the general language exercises. Laura took great pains with her work, and as her fellow-pupils were greatly interested in it, I give it as she wrote it, hoping it may be an inspiration to other boys and girls:- 


\section{VALUE OF BIRDS.}

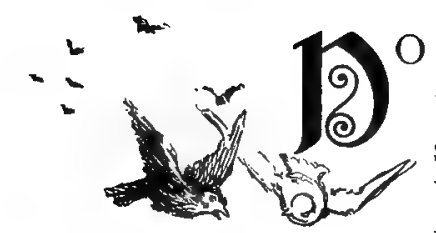

$\mathrm{O}$ WE often think how much we owe to these little friends? How much sweet music they bring into our lives? With what beauty and grace they delight our eyes?

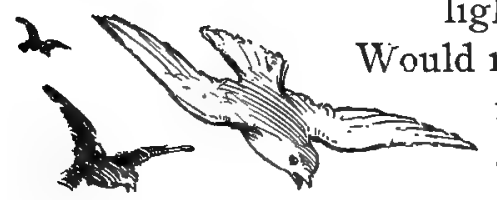

not half the joy of a spring morning be lost if their glad notes were silent? Would not the burdens of noonday seem heavier if no bird voice cheered us? And the evening shadows fall darker and sadder if they sang us no good-night melodies?

Before the crocus and the violet come to tell us of spring, the Bluebird and the Cardinal are here clothed in brilliant hues, bright harbingers of nature's resurrection.

They not only make life happier, but they make life possible by the destruction of noxious insects. Michelet says that in the hot climates life would be made intolerable by the myriads of insects that swarm there, if the birds did not keep them in check.

Vegetation everywhere would suffer from grubs and worms if there were no birds; yet in return for all these benefits
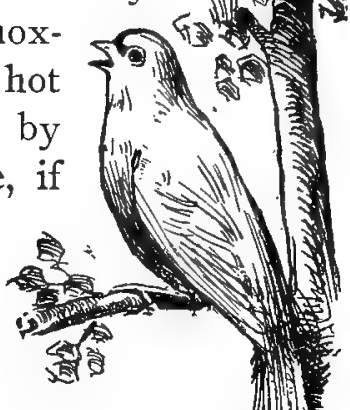
通管 
they have been persecuted and murdered until the life of a bird is one of constant fear. Longfellow has made a beautiful plea for the birds in his story of the "Birds of Killingworth." Some extracts from it I quote:

"Do you not think what wondrous beings these?

Do you ne'er think who made them and who taught

The dialect they speak, where melodies

Alone are the interpreters of thought

Whose household words are songs in many keys,

Sweeter than instrument of man e'er caught?

Whose habitations in the tree tops even

Are half-way houses on the way to heaven?

"Think, every morning when the sun peeps through

The dim leaf-latticed windows of the grove,

How jubilant the happy birds renew

Their old, melodious madrigals of love!

And when you think of this, remember, too,

'Tis always morning somewhere, and above

The awakening continents from shore to shore,

Somewhere the birds are singing evermore.

"Think of your woods and orchards without birds,

Of empty nests that cling to boughs and beams

As, in an idiot's brain, remembered words

Hang empty 'mid the cobwebs of his dreams!

Will bleat of flock or bellowing of herds

Make up for the lost music when your teams

Drag home the stingy harvest, and no more

The feathered gleaners follow to your door? 
"You call them thieves and pillagers, but know

They are the winged wardens of your farms,

Who from the cornfields drive the insidious foe,

And from your harvest keep a hundred harms;

Even the blackest of them all, the crow,

Renders good service as your man at arms,

Crushing the beetle in his coat of mail,

And crying havoc on the slug and snail.

"How can I teach your children gentleness

And mercy to the weak, and reverence

For Life, which, in its weakness or excess,

Is still a gleam of God's omnipotence?"'

* * * * * * * * * * * *

Just before the Christmas vacation Miss Sweet said to her pupils: "Next term, instead of our usual miscellaneous morning exercises, I want to spend the time in talking and learning about birds, and, as Laura was the first one to introduce the subject to us, I desire her to prepare a composition on the 'Migration of Birds,' to be read when school opens after the holidays." Laura felt quite willing to spend part of her vacation in this way, and immediately wrote to her aunt, asking all sorts of questions. When her aunt read the letter, she exclaimed: "A little leaven leaveneth the whole lump." (If you do not know what she meant, and where the quotation comes from, get some one to tell you.) In due time Laura received the answers to her questions, and meantime she had been hunting through all the bird books in 
her father's library, and talking so much about the subject that her father and mother became almost tired of her anxious enthusiasm, but, at last, the writing was finished, and the eventful Monday morning came. Miss Sweet had written to several of the pupils to learn the poems she sent them, so there was a manifest air of interest and expectancy as the pupils took their seats and scanned the following programme, which was written on the blackboard:

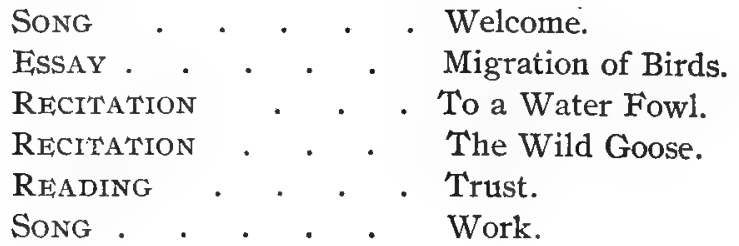

The song was given with spirit, and the entire programme carried out satisfactorily. Miss Sweet read "Trust" herself, as she knew that her pupils always considered it a treat when she could read to them. The pupils said after school that night that it put them in sympathy with the birds to hear Miss Sweet recite that poem.

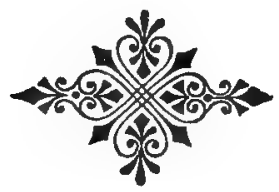




\section{MIGRATION OF BIRDS.}

(G) NE.OF the strangest things to understand about bird life is their annual migrations. We can readily see why they leave the north on the approach of winter and seek a warmer climate; not only because so many $\_$birds could not find sufficient shelter, $\square$ but because their supply of food is cut off when the insects dis- appear. A few birds like the Jay, the Chickadee, and Woodpecker that are not depend-

winter in

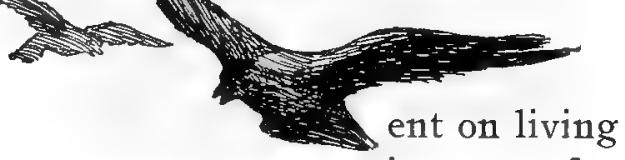
insects for homes; but the ngreater number are forced to move southward when the frosty nights of autumn drive the insects into their hiding places.

When they go, and how they go, are still subjects of mystery.

A few species, like the Wild Geese and Ducks, are sometimes seen flying in great flocks high up in the air, but many disappear and no one can tell the manner of their flight. Blackbirds, Crows, Bobolinks and others collect in large numbers before they are ready to go. 
The Crows go through a sort of drill, in the autumn, as if they were preparing for the long journey. One old leader gives the commanding "Cawcaw," and the others fall into companies and battalions and away they go, only to swing and whirl and countermarch (or counterfly) back to the starting point, where they alight amid a perfect din of "Caw-caws" and "Haw-haws."

After a few days of such maneuvers, they settle upon a time when the real start is made.

The flight of the Wild Geese is well known to . be in an orderly and exact manner, with a leader ir. front, while the others follow in the order of one or both sides of a wide $V$.

They never go in "Indian file," one immediately behind another, but in this form that enables each one to keep the leader in sight as well as to see which way they are going.

Many birds migrate only at night. When the nights grow cool a restlessness may be observed among the birds; a moving and chirping and low calling to each other in the darkness that is never heard in the summer nights.

On some dark night a sound of many bird voices is heard, a sound that seems far away and yet overhead; then we may know that a vast company of our summer friends are passing, under the cover of darkness, away to a land of sunshine and plenty.

The morrow may find the winds whistling through 
the bare branches where lately they swung their hammocks and built their summer homes; the rain and sleet may cover the fields where Bobolink and Meadowlark hid their babies' cradles; the clouds may hang dark and heavy between us and the sky, but the birds will greet the sunrise amid the orange groves of Florida or the green islands of the Atlantic.

And when the winter snows have melted, and the warm spring sun is calling bud and blossom back to life, some morning we awake to find the birds are come again. The very Robin that built his nest in our apple tree last summer is back again in our dooryard; and the self-same Oriole that swung his basket from a branch of yonder elm, is piping his gayest notes from its topmost branch. Twice they have traveled those weary miles over land and sea since last we heard them.

This is the mystery,- - how they know the way.

\section{TO A WATERFOWL.}

BX WILIIAM CULIEN BRYANT.

There is a Power whose care

Teaches the way along that pathless coast,

The desert and illimitable air-

Lone wandering, but not lost.

All day thy wings have fanned At that far height, the cold, thin atmosphere;

Yet stoop not, weary, to the welcome land,

Though the dark night be near. 
And soon that toil shall end;

Soon shalt thou find a summer home, and rest

And scream amlong thy fellows; reeds shall bend

Soon o'er thy sheltered nest.

Thou'rt gone; the abyss of heaven

Hath swallowed up thy form; yet in my heart

Deeply hath sunk the lesson thou hast given,

And shall not soon depart.

$\mathrm{He}$, who, from zone to zone,

Guides through the boundless sky thy certain flighc,

In the long way that I must tread alone

Will lead my steps aright.

\section{THE WILD GEESE.}

BY JAMES HIRBERT MORSE.

The wild geese flying in the night behold

Our sunken towns lie underneath a sea

Which buoys them on its billows. Liberty

They have, but such as those frail barques of old

That crossed unsounded mains to reach our wold,

To them the night unspeakably is free;

They have the moon and stars for company,

To them no foe but the remorseless cold, And froth of polar currents darting past,

That have been near the world's end lair of storms:

Enormous billows float their fragile forms.

Yes, those frail beings tossing on the vast

Of wild revolving winds, fecl no dismay

'Tis we who dread the thunder, and not they. 
OUR FRIENDS, THE BIRDS.

\section{TRUST. \\ BY BENJAMIN F. L,EGGETT.}

Once more the song birds set the air athrill

With symphonies of praise,

And birds and blossoms grow to music's trill

In warm and sheltered ways.

How fair the earth in tender green arrayed,

How sweet the wild notes sung,

When tufted branches weave a web of shade

And new made nests are swung.

How know the wild birds when to take the wing

From southern grove or clime?

What voices tell the dreaming earth that spring

Has brought the waking time?

Nay, question not nor doubt but birds can tell

The time to come and go,-

The earth to wake the sweet flowers in the dell,

Doth God not always know?

When the exercises were finished, Miss Sweet expressed her appreciation of their effort, and then said: "I have prepared a list of names of birds with which I thought it would be easy to begin our lessons, as they are all familiar, and most of us will find some opportunity for personal observation. I have asked Laura to prepare a scientific description of each bird, which, for convenience, we will call a 'table.' Wé will begin each day's lesson with this 'table,' which I desire you 
to copy carefully into a note book, with the list of birds we are studying, and other matters of interest that may come up."

RESIDENT BIRDS.

$\begin{array}{lc}\text { Blue Jay, } & \text { Einglish Sparrow, } \\ \text { Crow, } & \text { Owl, } \\ \text { Dove, } & \text { Quail. } \\ \text { Wondpecker (casual resident) }\end{array}$

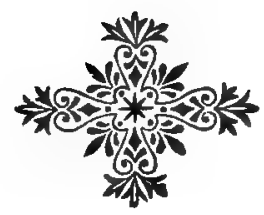




\section{THE BLUE JAY.}

(Cyanocitta crista'ta.)

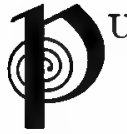

URPLISH BLUE, below pale purplish gray, whitening on the under parts. A black collar on lower throat and up the sides of the neck and head behind the crest. Black frontlet bordered with whitish. Tail feathers, except the central, broadly tipped with pure white. Tail much rounded. Length 11 to 12 inches. Extent 16 to 17 . Female not so richly colored. Eastern North America. Half migratory. Nest in trees or bushes, or any odd nook, large and substantial. Eggs five to six, drab colored, with brown spots.

One of Miss Sweet's pupils had a talent for drawing, which had been carefully cultivated. The pupils in this school were inclined to give good-natured nick-names to each other, so he was dubbed "Artist." He had come early to school and drawn in colored chalk a beautiful Blue Jay, perched on a dead limb just over the "table" which Laura had put upon the blackboard the night before. This was a pleasant surprise to both teacher and pupils.

"I saw several Blue Jays in our garden this morning," said Laura. "They were on the evergreens. They looked beautiful with their blue coats against the dark green background."

"I saw one when I first got up this morning," said "Artist," "and it was the real bird that suggested the picture." 


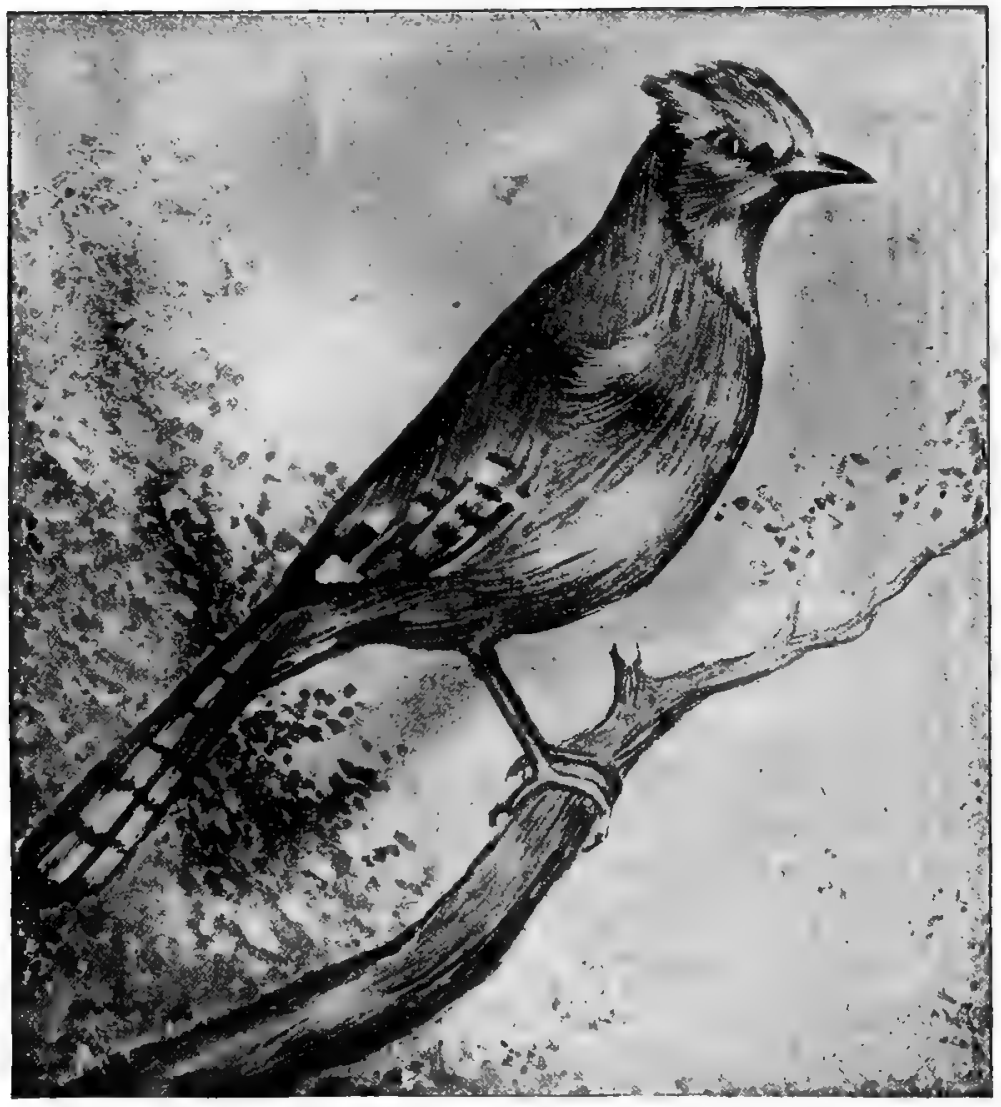

\section{BLUE JAY. \\ [ONE-THIRD LIFE SIZE.]}

Pictures of all birds in this book, and hundreds of others in correct colors may be hat at 2 cents each. Send to publishers of book for full list. 
"We are much obliged to him," said Miss Sweet. "He seems to be quite common here, and, as Laura suggests, he makes a pretty picture, giving to our northern landscapes the only coloring of bird life that they possess after the snows begin to fall. The Cardinal Grosbeak returns very early, as also the purple Grackle.

"These three make a bright picture when they come about the door-yard on a snowy March morning, the Cardinal with his scarlet coat, the Jay in his suit of blue, and the yellow-eyed Grackle dressed in purplish brown with head of iridescent green.

"To the Jay's habit of burying nuts in the ground, we owe many of our fine forest trees. He buries more than he ever digs up. I once saw a Jay carrying away pumpkin-seeds that were drying in the sun, and placing them in crevices of the fence, he covered them carefully with bits of moss.

"He utters some harsh notes, and others that have a bell-like melody."

Laura had told her teacher of a story her aunt wrote for her about some Blue Jays in their garden, and Miss Sweet asked her to bring it to school and read it. It is entitled: 


\section{THE BLACK SHEEP.}

It was one of those bright mornings that sometimes come in March, when the sun rises bright and clear and melts away the last drifts of snow that linger on the northern slopes. A warm breeze came from the south that caused people to throw up their windows and begin to dream of spring.

Suddenly, from the top of a tall tree in the yard, there rang out the clear, bell-like "to-loo-loo" of a company of Blue Jays. Everybody came out and looked for the singers. People who were passing stopped, looked up, and passed on with a more cheerful step. It may have been because they were the first bird notes of the year, that they attracted so much attention.

After hearing nothing but the chatter of English Sparrows for so many weeks, the first ringing notes of the Jays were welcome music; but who would stop to listen to them after the Bluebirds and Robins came?

For a few days they came about the yard in a flock, then all but one pair left. These birds built their nest in a pine tree near the house. The nest was a great clumsy affair of sticks, and dirt, and feathers.

One day, going out to look at something in the yard, I saw what, at first, looked like a bunch of bluish white feathers on a dead branch, that was lying on the ground. Looking closely, I found it was a young Jay, just out of the nest. He sat there with his head drawn down, not moving a feather until I touched him; then 
he gave a little "squawk" that brought the old birds about my head in a flash.

He could hop about in a lively manner, but was not much inclined to move unless urged with a stick or the parents' sharp commands.

Several times he was picked up, but every time the old birds gave a scream, and flapped down on the head of the officious person who dared to touch their baby.

In the evening, fearing a cat might get him, I threw him up into the pine, where he caught and held to the branch until the next day. The others never came to the ground, but remained near the nest until they learned to fly.

They seemed to be too sleepy, for awhile, to try to fly. The old ones coaxed and scolded, and flew back and forth over them to show them how to fly; but they would merely rise up on their long legs, stretch one wing slowly, then the other, and settle down for another nap.

After a few days they learned to fly about the tree, but the one who had fallen to the ground was more trouble to the parents than all the rest. $\mathrm{He}$ must have been the black sheep of the family. The feathers never grew on his head and neck, like the others, but he was always bald-headed and without a necktie. His neck was so slim as to remind one of a vulture. He must have taken a cold going with a bare neck, for, as he grew older, his voice became harsh and 
his tones querulous, as though he had a bad temper. Perhaps some one had told him how ugly he was.

The whole family remained about the yard all summer, and in a few weeks grew so much like the old ones that I could not distinguish one from another except poor "Baldy," as I called him. His head and his voice marked him from all other Jays.

Some Sparrows were in the habit of coming down every morning for the crumbs that were thrown to them. Sometimes one of them would catch up a large crumb and fly up to the roof or the grape arbor to enjoy it all alone; but no sooner did he alight than "Baldy" was beside him and snatched it away before he could take a mouthful.

The others were all well-behaved birds, worked for their living, and attended strictly to their business, which was helping everybody in the neighborhood to keep Poor Richard's maxim: "The early bird catches the worm."

The pupils recited in concert the following lines by Isabella W. McConike:

The prettiest picture that I ever have seen

Is a beautiful snow-crowned evergreen;

While in and out the branches all day

Idly flitteth the brilliantly robed Blue Jay;

His plumage as blue as violets in May,

But his heart, like the charmer's, cruel and gay.

Miss Sweet read Eben Pearson Dorr's poem on : 


\section{THE BLUE JAY.}

The Jay he sings a scanty lay, As boy who would a fiddle play, Strikes one bar from tuneful harp Then screeches into discord sharp. Though boys to task again can turn, The bird, alas! may never learn. Creator placed within his throat A song that is a single note.

Yet sweet this mellow minor chord, Prelude, perhaps it pleased the Lord, To song reserved for other shore Now vaguely hinted-nothing more.

When she had finished, she said: "We have still a little time for the questions, which will help us to see how much we have learned."

QUESTIONS.

Have you ever watched Jays build a nest?

Where do they build?

What kind of nest do they build?

Do you think a Jay as handsome as an Oriole?

Does he migrate?

Have you ever heard how he helps to plant forests? Is it not possible that he planted some of our Arbor Day trees?

What can you say of his singing?

Is he a good neighbor to other birds?

Is he a friend to the farmer?

Is he honest?

Is he peaceable?

What is the best thing you have read about him? 


\section{CROW. \\ - (Corvus frugi'verous.)}

HE COMMON CROW is a foot and a-half long. Feathers of the throat oval, soft and blended. No snow-white plumage. Wings, tail, and back burnished. Head nearly dead black.

Female smaller than male.

Eastern United States. In settled parts of the country the Crow tends to colonize. Some of its roosts are of vast extent. Nest of sticks and trash, bulky. Eggs four to six, greenish, dotted and blotched with neutral tints, purplish and blackish brown.

Nest in trees anywhere in the woods, usually concealed with some art.

Voices highly unmusical. They walk firmly and freely on the ground.

There was a suppressed excitement that was quite evident as the pupils gathered in the school-room this morning, for there had been a good deal of discussion the night before, while they had been copying the "table" in their note books.

"I feel as though we were going to try a criminal," said an imaginative girl.

"Ho! a Crow is smart enough to go to college," remarked a boy, as though that settled the matter.

"Because he's smart is no sign he is good, is it, Miss Sweet?" asked a boy whom the pupils laughingly called "Querist." 


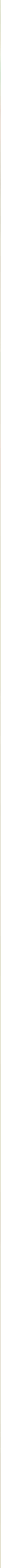



OUR FRIENDS, THE BIRDS,

Miss Sweet replied: "Unfortunately they do not always go together. The Crow seems to be regarded by men and birds almost in the light of a criminal."

"But is he really very troublesome?" asked "Querist."

"That can hardly be doubted, although some writers claim that he has no friends because he takes a little corn, while really he destroys more worms which would injure the corn. I have seen a flock of crows walking up and down the rows of newly-planted corn, while one sat on the fence to give an alarm if an enemy approached, and afterward the farmer told me that there wasn't much of the corn left. Another farmer told me that he believed that crows pull up the young corn out of pure mischief. He certainly has a bad reputation."

"My father told me," said the youngest member of the class, known as "Baby," "that he robs the Kingbird's nest and destroys the young birds, and so they will drive a Crow away whenever they can."

"Yes," and lots of other birds quarrel with him," said one of the boys.

Everyone had something interesting to tell, either from personal observation or from their reading, for

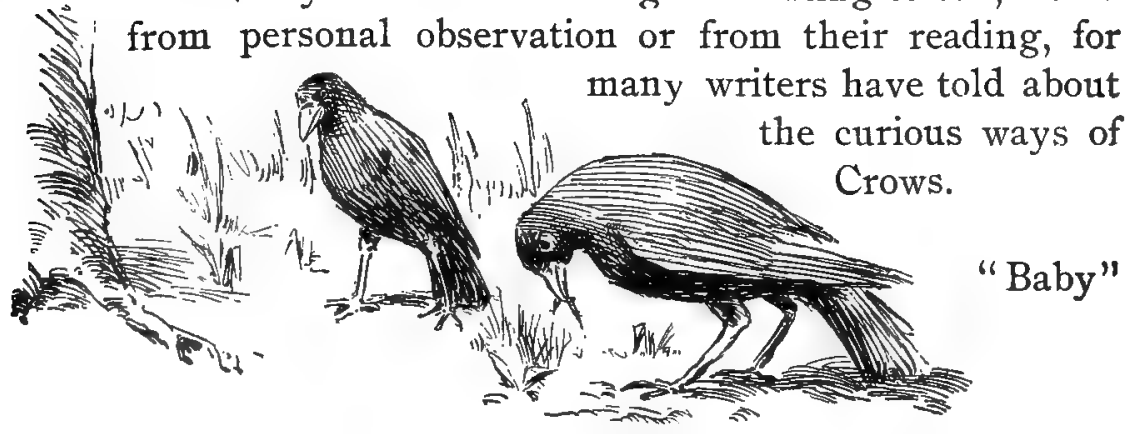


read the following quotation that she had found somewhere, but she neglected to get the author's name:

"Whenever one hears a flock of Crows cawing away in the woods, he may be assured that some excitement is afoot that will well repay his time and patience to investigate. Crows will persecute an Owl that is taking his noon-day nap;" and the author told of strange antics the young ones perform while the others sit around and applaud with loud "haw-haws."

One of the boys said: "I have read that Crows play a 'fox and geese' game, with some bright object." Another said: "My father told me that they have a sort of martial drill which they perform under one leader."

"I have found a poem on the usual theme, the Crow's sagacity, which I think will please you," said Miss Sweet. "It is called

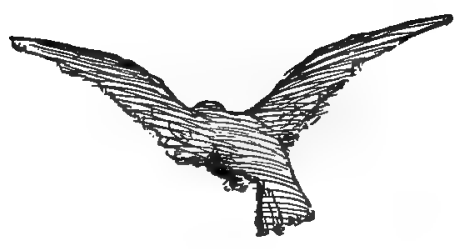


See how he stands with his arms stretched out!

$\mathrm{He}$ is calling the Crows from all about

Such a kind invitation is most alluring-

So very cordial and reassuring!

I think we had better accept, don't you?'

And down to the field of corn they flew.

QUESTIONS.

What interesting stories have you read about the Crow?

Have you ever witnessed any of these performances?

What do you know of his European cousins, the Rooks?

The people of Great Britain protect the Rooks on account of their great benefit to agriculture, why should not we protect the Crow?

Except Longfellow, what poet has said a word in favor of the Crow? Do Crows migrate?

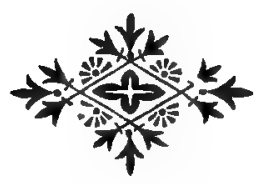




\section{MOURNING DOVE.}

(Zenaidu'ra carolinen'sis.)

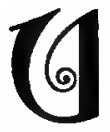

PPER parts grayish blue shaded with brownish olive; head and neck ochry brown, the sides of the neck glittering with golden and ruby iridescence. Under parts purplish. Black spots on some of the wing coverts. Lateral tail feathers, plumbeous-bluish crossed with a black bar. Outer four ended with white. Bill, black; iris, brown; bare skin around eye, livid bluish; feet, red. Length, 12.50; female somewhat smaller and duller in color.

Temperate North America, everywhere. Irregularly migratory. Almost always feeds on the ground. Nest on ground or in bushes; sometimes in trees. Eggs, two, white, equal ended. Their cooing continues through the mating season.

"Laura's table," said Miss Sweet, "is about the Mourning Dove, which obtains its name from its plaintive note. It is also called Carolina Dove. The name Dove seems to be given to the smaller members of the group of birds which by ornithologists are commonly called Pigeons. I have included it with the resident birds, because I desire you to observe the habits of domestic Pigeons.

"The Dove from the earliest period in history has been associated with the idea of a messenger (Genesis viii., 8-12), which is, I believe, the first place in the Bible where the Dove is mentioned. Its use as a mes- 
senger has been developed by various races, and many instances of its usefulness are known in our own day. But, although doves in a wild state are very powerful on the wing, they are feeble walkers, as they have very small feet and legs. Almost the only notes they utter is a gentle cooing. They are so gentle that they are used as a symbol of purity, and also of innocence, gentleness and affection. In Christian art they are an emblem of the Holy Spirit, and with an olive branch in the mouth one of peace.

"The Mourning Dove is among the earliest arrivals from the south. Laura has a story to tell about a pair that built their nest near her house last spring."

"A pair came to our lawn last March. Before the snows were entirely gone they were walking about in their gentle, graceful way, always together. They built a rude nest in the lower limbs of a pine tree just over the hydrant.

"The last week in April I found two young birds in the nest. Both parents fed them in the same way; by placing their bills in the mouth of the young and giving a shaking motion, which sent the milky, halfdigested food from the parent's crop into that of the young.

"They all stayed about the nest for several days, and then went away. The last week of July the pair returned and used the same nest."

"What is the difference between Pigeons and Doves ?" asked "Querist." 
Miss Sweet waited for some one to reply, and Iaura said: "I asked auntie that question once, and she said that no sharp distinction can be drawn between them, and in general literature the two words are used indifferently, while no one species can be pointed out to which the word Dove alone seems to be absolutely proper."

"Then, I should think, if we observe the habits of tame Pigeons, we could learn a good lesson about Doves in general," remarked a girl.

"That is true," replied Miss Sweet. "Have you ever heard this couplet by Bishop Doane? Please repeat it with me:

"Ever, my son, be thou like the Dove,

In friendship as faithful, as constant in love."

"Here is a poem by D. Conway that I admire very much," and Miss Sweet recited

\section{TO THE TURTLE DOVE.}

Deep in the wood, thy voice I list, and love, Thy soft complaining song, thy tender cooing; Oh, what a winning way thou hast of wooing! Gentlest of all thy race-sweet Turtle Dove. Thine is a note that doth not pass away Like the light music of a summer day; The merle may trill his richest song in vainScarce do we say, "List!" for he pipes again. But thou! that low plaint oft repeating To the coy mate that needs so much entreating 
Fillest the woods with a discursive song Of love, that sinketh deep and resteth long; Hushing the voice of mirth and staying folly, And waking in the heart a gentle melancholy.

She had written on the board the following lines by William $\mathrm{H}$. Hayne, which the school repeated in concert:

"Oh, come to the meadow with me

While the music of the morning is heard And the rhythmical rapture of song

Is sent from the heart of a bird!

Come hither and wander with me

For nature is breathing of love,

From violets veiled in the grass

To the tremulous wings of the Dove."

QUESTIONS.

What do you admire most about the Dove?

When does its "cooing" commence?

Does its first notes create a feeling of sadness or of joy?

Why?

How does it build its nest?

Have you seen one feed its young?

Is it a walker?

How does it compare with other birds in powers of flight?

Where is the first Dove mentioned in the Bible?

How often is it mentioned there? 


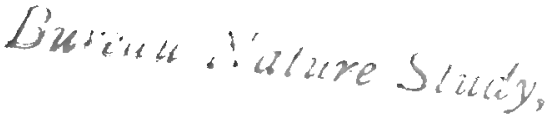

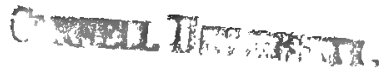 \\ libaca, N. I I}

\section{ENGLISH SPARROW.}

\section{(Pas'ser domes'ticus.)}

PPER PARTS ashy gray; middle of back and scapulars boldly streaked with black and bay. A dark chestnut or mahogany space behind eye, spreading on side of neck. Lesser wing coverts deep chestnut. Lower parts ashy, gray or whitish; chin and throat, jet black; bill, blueblack.

Female, above brownish gray. Streaking of back light ochrey brown and black. No black, mahogany, or white on head. Bill blackish brown.

Imported about fifteen years ago, this sturdy little bird has overrun the whole country and proved a nuisance without a redeeming quality.

"I think the Sparrow is abused" said Laura. "One of our neighbors burns sulphur and kills scores of them, or stupefies them so that she picks them up and buries them. It seems wicked to me."

"Sometimes I get tired of their constant chirping," remarked a quiet girl, called "Student" by her companions.

"Do you think they really drive our song birds away?" asked "Querist."

"I believe it is not really true," replied Miss Sweet. "About every country home, and in small 
towns, we still find all of our native birds. If they are not so plentiful as they once were it is more the fault of man than of the English Sparrow, for if we go out to the fields and woods, a short distance from any dwelling, we seldom hear a Sparrow. Many city children would never have a glimpse of birdlife if there were no Sparrows. This is 'their excuse for being.'" "Some folks say they are quarrelsome," remarked "Baby," "but I've watched them for hours and I never saw them disagreeable. Only the other morning one lit on top of the piazza, in front of my window. It had a piece of hard bread in its mouth, which it laid down and began to peck at. I suppose it was all the breakfast it was likely to get. Pretty soon another one came and tried to get some of the bread, but the first Sparrow picked it up, and turning his back

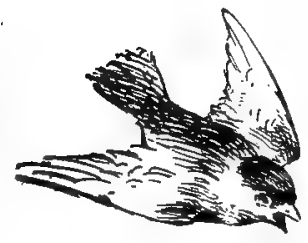
on the other, tried to finish its breakfast. The other one looked about a little while, and then made another attempt to secure some of the bread, which was evaded as before. Just then another one came and began to bother in the same way. The first picked up its bread, flew to the farthest

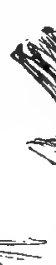
Sparrow
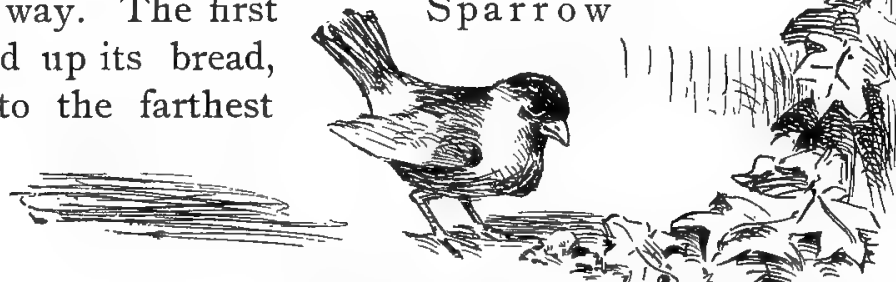
corner of the piazza, turned his back as before, and coolly ignoring his friends went on with his breakfast. The other two stood looking at each other for a little while and then flew away. It was very funny. None of them seemed to be the least bit out of temper, but I imagined they were saying to each other, 'How selfish he is.' I saw it several times apparently pecking at the same piece of bread.

"I have seen them fly at other birds," said a boy. "May be they are only amiable among themselves." "That would be different from some folks," said "Student."

"Time is nearly up," said the teacher. "I will recite D. S. Pickley's verses about the Sparrow:"

You may talk about the Nightingale, th' Thrush 'r Medder Lark, ' $R$ any other singin' bird that comes from Noah's ark;

But of all feathered things that fly, from Turkey-buzzard down, Give me the little Sparrer with his modest coat o' brown.

I'll admit thet in th' springtime, when the trees are gettin' green, When again the Robin Readbreast 'nd th' Bluebird first 're seen; When the Bobolink 'nd Blackbird from th' southland re-appear, ' $N d$ the Crow comes back to show us thet th' spring is really here-

I'll admit thet in the springtime, when the groves with music ring,

Natur' handicaps the Sparrer; he was never made to sing;

But he sounds th' Maker's praises in his meek 'nd lowly way;

And tho' other birds come back at times, he never goes away.

$$
\text { * * * * * * * * * * * * * * }
$$


'Nd even in midwinter, when the trees ' $r$ brown 'nd bare, 'Nd th' frosty flakes 're fallin' thro' th' bitter bitin' air, The Sparrer still is with us t' cheer us when we' re glum, Fer his presence is a prophecy of better days t' come.

'The Sparrer's never idle, fer he has t' work his way;

You'll always find him hustlin' long before the break o' day;

He's plucky, patient, cheerful, 'nd he seems t' say t'man,

I know I'm very little, but I do the best I can.

What more can you 'nd I do than t' always do our best?

Are we any more deservin' than the little British pest?

So, when you talk of "feathered kings," you'd better save a crown

Fer the honest little Sparrer, with his modest coat o' brown.

\section{QUESTIONS.}

What do you think of the English Sparrows?

Are they quarrelsome?

Did you ever see them fighting other birds?

Have you ever watched them building their nests?

Tell some incident of Sparrow life that you have observed.

Longfellow says:

"The Sparrows chirped as if they still were proud Their race in Holy Writ should mentioned be."

To what does he refer? 


\title{
SCREECH OWL.
}

\author{
(Scops a sio.)
}

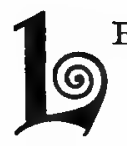

ENGTH 8 to 10 inches. Upper parts brownish gray in dappled pattern of lighter and darker shades, finely streaked with black. Wing-quills dusky, the outer webs with several white or buff spots. Lining of wing yellowish white. Under parts white streaked and blotched with wavy crossbars. Iris, yellow; bill, slate gray; claws, blackish.

Nestlings are covered with white down. Eastern United States and Canada to the Rocky Mountains. Breeds about buildings, in stumps and hollow trees. Food mice, small birds and insects. Nest a slight structure in the hollow selected. Eggs five to six, white, subspherical.

"Artist" was again up betimes and had perched a very wise looking owl on a dead branch of a tree with the moon shining behind him. Miss Sweet was so much pleased that she left the picture on the black board until after the Friday afternoon exercises that some of the parents might see it.

Several of the pupils had never seen a Screech Owl, and knew him only by his voice, and had, therefore, a poor opinion of him as a bird. Others had a better acquaintance with him and admired his beautiful plumage, and spoke of the almost human look he has as he 


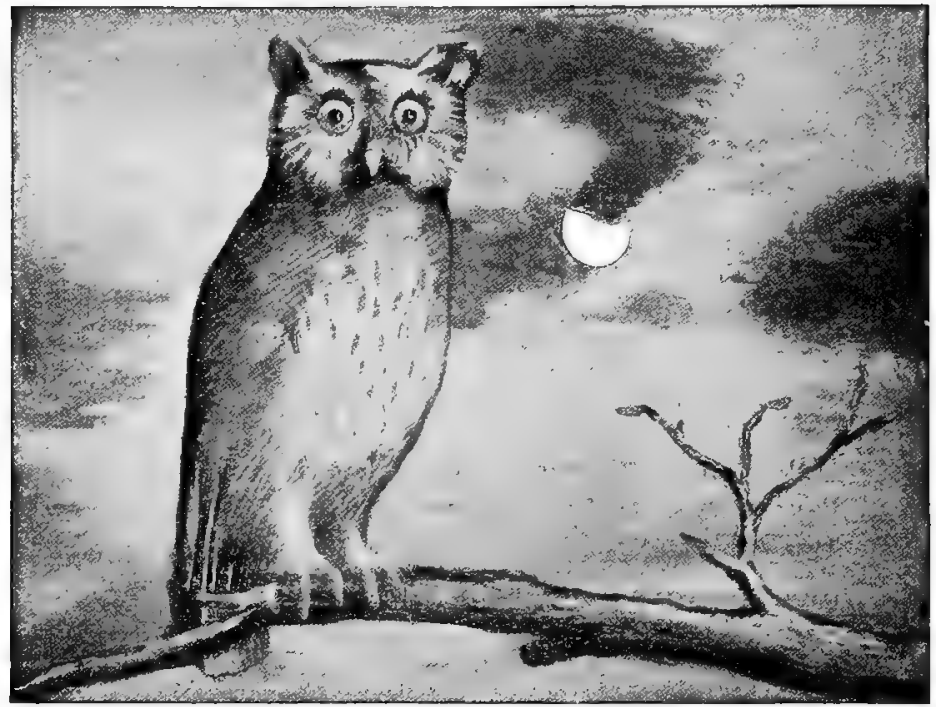

SCREECH OWL.

[ONE-FOURTH LIFE SIZE]

sits upright on his perch and slowly and gravely turns his head to give an inquiring stare at any intruder.

Miss Sweet said: "Timid and superstitious people find no 'poetry of sound' in the hooting of an owl, but shrink from it as a sound of evil and woe. If they but understood his language they would know that he is only wooing Mrs. Scops, and to her his tones are as sweet and musical as the 'love song of the Veery' to his mate."

"They are useful in ridding us of rats and mice," said a practical boy. 
"I found a nest once in a dark corner of my grandfather's barn," said "Artist." "It had four blue tinted white eggs in it. I thought at first it was a hen's nest, until I saw the eggs. I didn't stay there long enough to see the young owls."

"Don't you think the poets help to make the Owl an unpopular bird, Miss Sweet?" asked "Querist."

"Perhaps so." Poets usually call him a melancholy bird.

"The boding owl, upon the evening gale
Sends forth her wild and melancholy wail."
"The moping owl doth to the moon complain",

and such expressions are very commonly found in poetry. Burns in his poem 'To the Owl' says:

Sad bird of night, what sorrows call thee forth

To vent thy plaints thus in the midnight hour?

* $\quad * \quad * \quad * \quad * \quad * \begin{array}{lllllll}* & * & * & * & *\end{array}$

From some old tower thy melancholy dome,

While the gray walls, and desert solitudes

Return each note, responsive to the gloom

Of ivied coverts and surrounding woods.

There hooting, I will list, more pleased to thee

Than ever lover to the nightingale;

Or drooping wretch, oppressed with misery,

Lending his ear to some condoling tale. 


\section{Barry Cornwall sings :}

Mourn not for the Owl nor his gloomy plight

The Owl hath his share of good;

If a prisoner he be in the broad daylight,

$\mathrm{He}$ is lord in the dark greenwood!

Nor lonely the bird, nor his ghastly mate;

They are each unto each a pride;

Thrice fonder, perhaps, since a strange dark fate

Hath rent them from all beside!

We know not always who are kings of day,

But the king of the night is the bold brown Owl.

QUESTIONS.

Why does the Owl have few friends?

Is not the Owl more useful than the cat?

Why is the flight of the Owl so noiseless?

Where do you find the Owl's nest?

Why does the Owl have a more human-like look than other birds?

Where do Owls stay in winter?

Can Owls be tamed?

In what scenes do the poets always speak of the Owl?

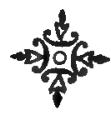




\section{QUAIL. BOB-WHITE.}

(Or'tyso virginia' na.)

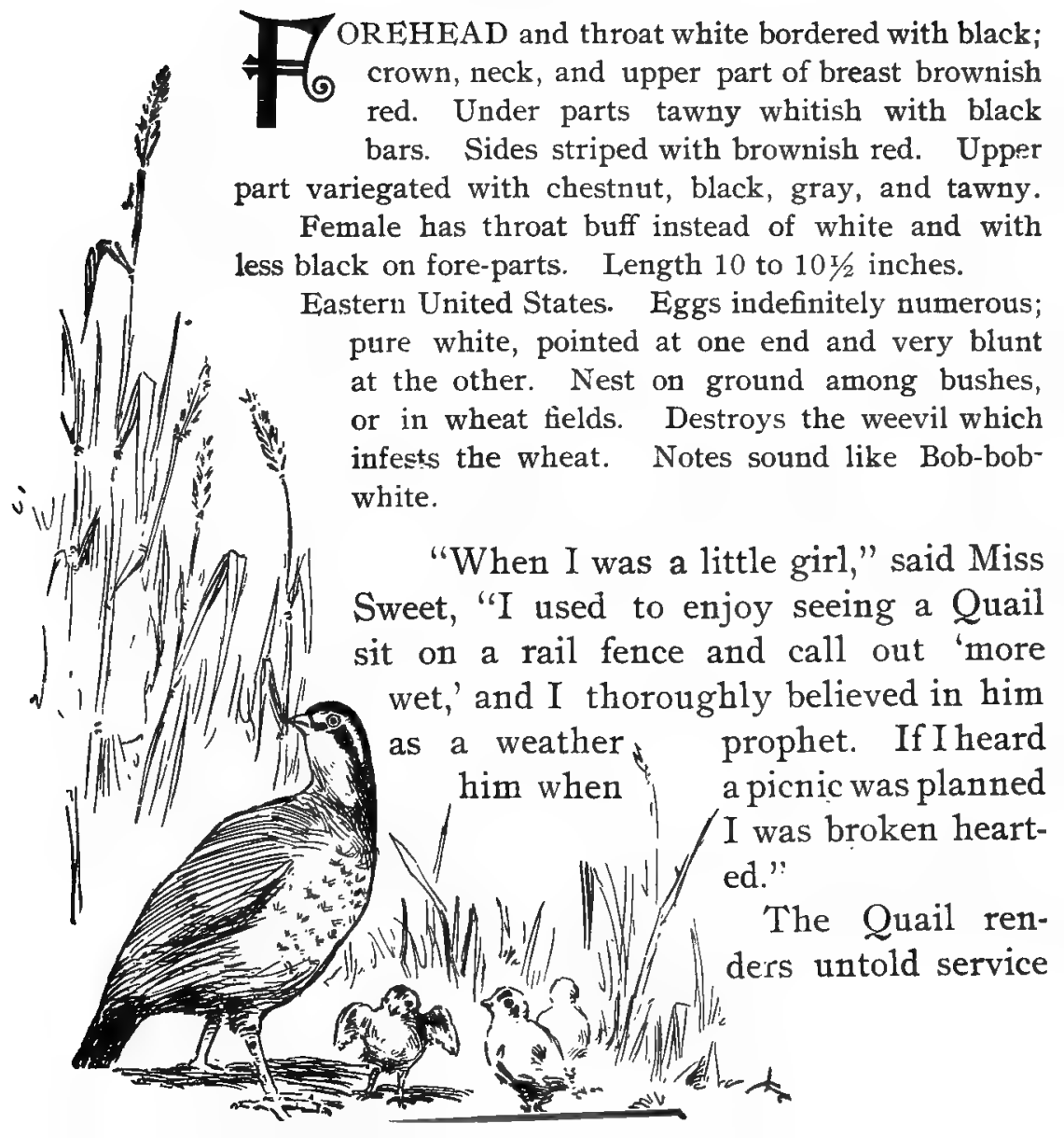


to the farmer by destroying the wheat weevil and other troublesome insects; yet they have been so hunted down, trapped, and shot, that did not the law protect them they would be exterminated.

"They are more timid and less plentiful than they once were, yet we may still hear them in the wheat fields calling, 'Here's Bob White.'

"The young ones leave the nest as soon as hatched. They are very active little things, and can hide away in an instant. A quick flutter of the mother's wings and every chick disappears under a leaf or tuft of grass. Then she tries to lure you away from them by pretending to be hurt and trailing herself along the ground.

"The Quail is a great favorite with poets.

"I will recite some verses that I like very much, although I do not know the author, entitled

\section{WHO IS IT?}

Down in the meadow in the bright June weather, Where violets and sweet flags grow, Amid the waving grass and breezes iight, I hear a voice calling: "Bob-White" "Bob White."

Who is it whistling the long June day, Down where the waters glisten?

A bird small and brown, a wandering sprite,

I hear him loudly calling:

"Bob-White" "Bob: White." 
Where are you, Bob, and what have you done,

That he calls you day by day?

Perhaps you staid away in the night

And home now he is calling:

"Bob-White," "Bob White."

Maybe you're held by a wood nymph's spell,

A captive in a dell wild and sylvan,

And there you are hid from mortal sight,

While plaintively he's calling:

"Bob-White" "Bob White."

Miss Sweet imitated the bird's call so well that the pupils forgot their usual school room decorum and applauded vigorously. She then recited Marion Franklin Ham's

\section{BOB-WHITE.}

Shrill and clear from coppice near,

A song within the woodland ringing

A treble note from silver throat,

The siren of the fields is singing-

Bob-bob-white!

And from the height the answer sweet

Floats faintly o'er the rippling wheat

Bob-white.

The elder flowers in snowy showers

Upon the velvet turf are falling;

And where they lie the soft winds sigh

The while the fluted voice is calling-

Bob-bob-white!

And far across the yellow grain

The wafted echo swells again

Bob-white. 
The purple mist by sunbeams kissed

Drifts upward toward the morning's splendor And throutgh the haze of shaded ways

The plaintive reed pipes low and tender-

Bob-bob-white.

While fainter, sweeter, softer grown

The answer on the breeze is blown-

Bob-white.

The shadows sleep in hollows deep;

The dewy paw paw leaves are thrilling;

The silence broods o'er solitudes,

Unbroken, save one pure note trillingBob-bob-white!

So pure, so clear, so sweetly rare, The answer steals upon the air-

Bob-white.

O song of youth! Of love and truth

Of mellow day forever dying!

Still through the years my sad heart hears

Your tender cadence sighing, sighingBob-bob-white.

And far across life's troubled ways The echo comes from boyhood days Bob-white.

QUESTIONS:

Have you ever met Bob White?

Where?

Was he anxious to become acquainted?

How did he look?

What did he say, Bob-white or More-wet? 
Did you see any of the little Bob Whites?

Do you know how they hide so quickly?

Don't you think it a pity to kill such an interesting bird?

Is he a very timid bird, or would he be sociable if men were more kind?

What is your favorite poem about him? 


\title{
RED-HEADED WOODPECKER.
}

\author{
(M. erythroce'phalus.)
}

$\Phi^{\text {(R) }}$

RI-COLOR, with "red, white and blue." Back, wings and tail glossy blue black. Tail coverts, wing coverts, and under parts white. Head, neck and fore-breast crimson, bordered with black where adjoining the white.

Red feathers stiffish and somewhat bristly. Gloss is sometimes green instead of blue. Length eight to nine inches.

Young are gray where the old are red. Eastern United States to Rocky Mountains. Migratory in some sections. Nest anywhere in woods, preferably in top of blasted tree. Eggs five or six, glossy and spheroidal.

Feeds on acorns, nuts, berries, and various fruits as well as insects.

"Our 'table' gives a scientific description of the Red-headed Woodpecker only, although we might find much to talk about in the Woodpecker family. This bird does not seem to care much for travel, and some winters he does not go south at all. He is a carpenter, and you can hear the tap of his little hammer if you will listen at the right time, and you may see his chips, that look like sawdust, where he has been building his house in the side of an old tree or high up on a telegraph pole. You can see only the circular door, but inside the house is shaped like a pear, and extends 


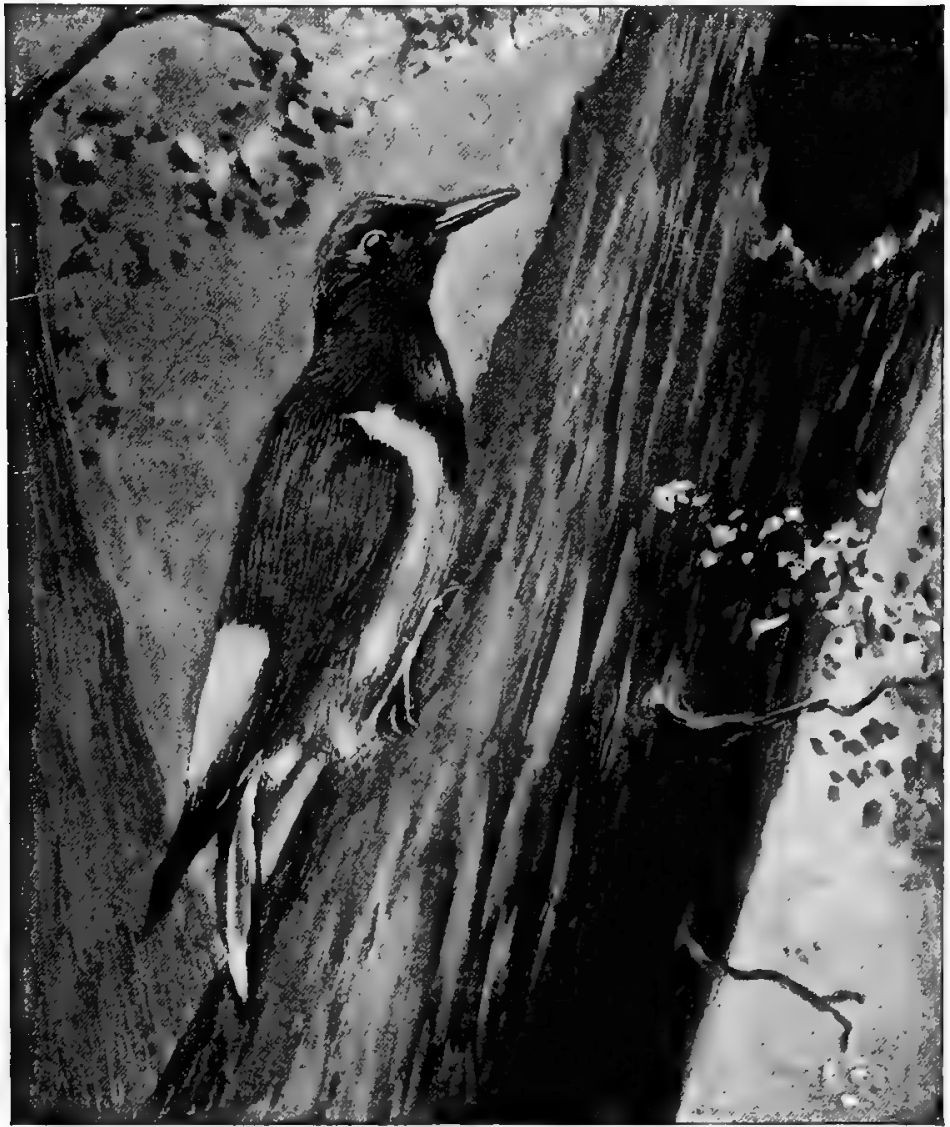

\section{RE,D-HEADED WOODPECKER.}

[ONE-HALF LIFE SIZE.]

deep down from the opening. He leaves a few chips for his bed.

"The Woodpecker belongs to that class of birds 
which law-makers have not yet decided to protect. Sometimes a tree is found girdled with holes made by the .Woodpecker, and we conclude that the tree will die. (Though it does not always die.) Sometimes we catch the 'red-head' eating corn or cherries, and straightway forget how many beetles and larvæ he has eaten before he takes his dessert.

"The Woodpecker is not a singer, he is a drummer. Have you ever been to a Thomas Concert? If you have, perhaps you have noticed at the back of the stage, almost out of sight, several drummers. They each had a part in the great orchestra, and yet, taken alone, their music would not be altogether agreeable. So, it seems to me, that the Woodpecker would be missed if left out of the great summer orchestra. He often drums 'for fun' or, perhaps, to give expression to the gladness of life, as other birds sing. Laura's aunt once wrote a story for her about the 'Wickey.' This is the Flicker or Golden-winged Woodpecker. She may read it to us."

\section{"WI CKEY."}

The son of a friend of mine, with the aid of a fivecent piece, once rescued from the hands of some rough boys a young Flicker, or Golden-winged Woodpecker.

Too young to fly, with only pin-feathers on its wings, it had dropped, or been taken from the nest.

He brought it home, saying, "Mother, can we not keep this bird until it is able to fly?" 
The mother being too kind-hearted to let it die without trying to save it, placed it in a box, and began feeding it carefully, with worms and insects.

In a short time it had grown so large that she turned it out in the yard, expecting it to fly away.

To her surprise, it stayed about the yard all day, and at night came into the porch to roost. After that it was allowed to come into the house or go out at its own pleasure.

Its voice was not musical but it had a little call like "Wickey, wickey," from which it was named.

It provided its own food, after being let out, from the trees and ant hills. Often when its mistress started toward the garden, it would alight on her head, ride out to the garden, and busy itself in hunting ants while she gathered the vegetables or berries for dinner.

In the afternoons, when she wished to take a nap, Wickey would sometimes come hopping into the room. She would say to him, "Now, Wickey, if you come in here, you must be quiet." Then folding her apron over the back of a chair, she would lie down, and Wickey would fly upon the apron, put his head under his wing, and take a nap too.

When his nap, which sometimes lasted a half hour or more, was over, out he would go again, into the trees. There he thrust his long tongue into crevices of the bark and feasted on the insects hiding there.

Sometimes when he came into the house and did not find his mistress he would call "Wick-ah" then 
pause, "Wick-ah," another pause as if listening, "Wickah," ustil he found her, when he would hop up to her and cry joyfully "Wick-ah, wick-ah, wick-ah, wick-ah, wick-ah, wick-ah" as fast as he could chatter.

Wickey wore a handsome dress. His back and wings were olive brown with many black bars. His tail feathers were black with golden shafts and undersurfaces; tail coverts, black and white; top, back and sides of head, ash with a scarlet crescent; under parts of head, lilac brown with black spots; under parts, yel. low with black spots; under side of wings, golden His feet were dark, and eyes brown.

At last poor Wickey came to an untimely death at the jaws of a neighbor's cat, and my friend says that she has tried many times since to pet a Flicker, but could never succeed in making another tame like Wickey.

Perhaps if he had lived longer she might have found him troublesome when his instinct for boring into wood had developed; especially if he had chosen some of her furniture on which to exercise his talent for boring.

John Burroughs, speaking of some Flickers drilling holes in an ice house, says:

"One bird seemed like a monomaniac, and drilled holes up and down, and right and left as if possessed of an evil spirit. It is quite probable that if a "highhole" or other Woodpecker should go crazy, it would take to just this sort of a thing, drilling into seasoned 
timber till it used its strength up. The one I refer to would cut through a dry hemlock board in a very short time, making the slivers fly. The sound was like that of a carpenter's hammer. It may have been that he was an unmated bird, a bachelor whose suit had not prospered that season and who was giving vent to his outraged instincts in drilling these mock nesting places."

You may recite in concert, Clinton Scollard's poem:

\section{THE WOODPECKER.}

When on the southern slopes

The drifts grow thin,

And buds like lover's hopes

To swell begin,

This truant comes

And drums

The springtime in.

He marshals out the May

For June to reign,

Filling the blithe blue day

With sharp refrain,

For lo! he knows

The rose

Is queen again. 
And when with golden mists

Is hazed the sun

And lover's moonlight trysts

In dales are done,

He sounds his call

To fall,

A ringing one.

When seres the lone last leaf

Upon its stem,

And barren days and brief

Our vision hem,

Then to the year

We hear

His requiem.

QUESTIONS.

Have you ever observed any of the queer antics of the Woodpecker?

If you were a bird which nest would you prefer, the Oriole's swinging hammock, or the Woodpecker's nest in a tree trunk?

Tell something, or give a quotation, about the Woodpecker. 


\section{BLACK-CAPPED TITMOUSE. CHICKADEE.}

(Pa'rus atricapil'lus.)

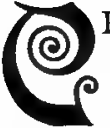

ROWN and nape, with chin and throat black, separated by white sides of the head. Upper parts brownish ash with slight olive tinge. Under parts white or whitish shaded on the sides with a brownish rusty wash.

Wings and tail like upper parts, the feathers edged with hoary white.

Eastern North America from the middle States northward.

Nest in holes of trees, stumps, or fences, natural or excavated by the bird; of hair, grasses, mosses, fur, feather's, etc.; eggs, six to eight white, fully sprinkled with reddish brown dots and spots. A hardy bird; four to five inches; not migratory.

"I desire the 'table' to be the most prominent part of every lesson, as that gives accurate scientific information," Miss Sweet remarked, as the pupils were quietly preparing for work, "so every lesson begins with it. We begin to-day with the Chickadee. I have selected the following birds for our coming lessons. Their names are familiar to us all, even if we have not been properly introduced to them in Birdland, as I hope we may be before we finish our lessons. I have arranged them, as nearly as possible, in the order of their coming:

Chickadee,

Cuckoo,

Belted Kingfisher,

Bluebird,

Robin,
Redwing Blackbird,

Killdeer Plover,

Song Sparrow,

Barn Swallow,

Wood Pewee. 
The children had frequently brought crumbs and seeds to school, wbich they scattered where they could watch the birds from the low windows, for, unlike most schoolhouses, these windows were not above the chi1. dren's heads.

Laura said: "I am well acquainted with the Chickadee, and have thrown crumbs to him ever since I can remember. He stays all the year, but no one notices him in summer among all the other birds."

"There's one now!" exclaimed a pupil who sat near the window.

Miss Sweet permitted them to go quietly where they could observe him.

"See him swinging and singing in a cool, careless way as though he meant to have a good time," remarked "Baby."

"Couldn't be much else but cool with the temperature at ten in the shade and snow everywhere," said a boy. "See his black cap and necktie," said another boy. "He doesn't wear gay colors; may be he's a bird Quaker?" said "Student."

"Is he much of a singer, Miss Sweet?" asked "Querist."

"He sings no brilliant song, but his bright little notes are as cheery on a sultry August afternoon, or a bleak December morning, as they are in the 'merry month of May.' 'The sounds from which he derives his name appear to be call-notes, and when repeated frequently a great number of them will assemble." 
Laura said: "My aunt once told me that the Titmouse was Emerson's favorite bird, and she taught me to recite some extracts from his poem entitled:

\section{THE TITMOUSE.}

Then piped a tiny voice hard by,

Gay and polite, a cheerful cry,

Chick-chickadee dee! saucy note

Out of sound heart and merry throat,

As if it said, Good day, good sir!

Fine afternoon, old passenger!

Happy to meet you in these places,

Where January brings few faces.

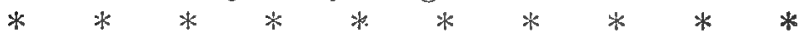

Here was this atom in full breath,

Hurling defiance at vast death.

This scrap of valor just for play

Fronts the north wind in waistcoat gray,

As if to shame my weak behavior;

I greeted loud my little savior,

'You pet! what dost here? and what for?

In these woods, thy small Labrador,

At this pinch wee San Salvador!

What fire burns in thy little chest

So frolic stout and self-possest?

Henceforth I wear no stripe but thine

Ashes and jet all hues outshine.

* * * * * * * * * * * * * * * * *

I think no virtue goes with size;

The reason of all cowardice

Is that men are overgrown,

And, to be valiant, must come down

To the Titmouse dimension. 


\section{QUESTIONS.}

How did Emerson regard the Titmouse?

Do you know the Chickadee when you see him?

In what way does he differ from the Pewee?

Where should we seek his nest?

Have you seen the Chickadee as often in summer as in winter?

Does the Chickadee ever say Phœbe?

Have you ever heard the Chickadee's Song from Hanson's Calisthenic Songs?

Why can the Chickadee live in the north in winter? 


\section{BELTED KING FISHER.}

(C. al'cyon.)

PPER PARTS, broad pectoral bar and sides under the wings, dull blue with fine black shaft lines. Lower eyelid, spot before eye. Under parts white. Quills and tail feathers black, speckled, blotched or barred on the inner webs with white. Wing coverts sprinkled with white. Feet dark. A long, thin, pointed crest. Plumage compact and oily to resist water, into which the birds constantly plunge after their finny prey. Length 12 to 13 inches. North America, common everywhere. This fine bird whose loud rattling notes are as familiar sounds along our streams as the noise of the mill-dam or the machinery, burrows to the depth of six or eight feet in the ground, and lays as many crystal white spheroidal eggs, at the enlarged extremity of the tunnel.

One of the girls began the lesson by reading the following quotation from Wilson Flagg:

"The King Fisher is singularly grotesque in his appearance, though not without beauty of plumage. $\mathrm{He}$ is a mixture of the grotesque and the beautiful which, considered in connection with his singularity of habits, may account for the superstitions which attach to his history. He sits patiently, like an angler, on a post at the head of a wharf, or on the trunk of a tree that extends over the bank, and leaning obliquely with extended head and beak he watches for his finny prey. "There with the light blue sky above him and the 
dark-blue waves beneath, nothing on the surface of the water can escape his penetrating eyes. Quickly, with a sudden swoop, he seizes a single fish from an unsuspecting shoal and announces his success by the peculiar sound of his rattle.

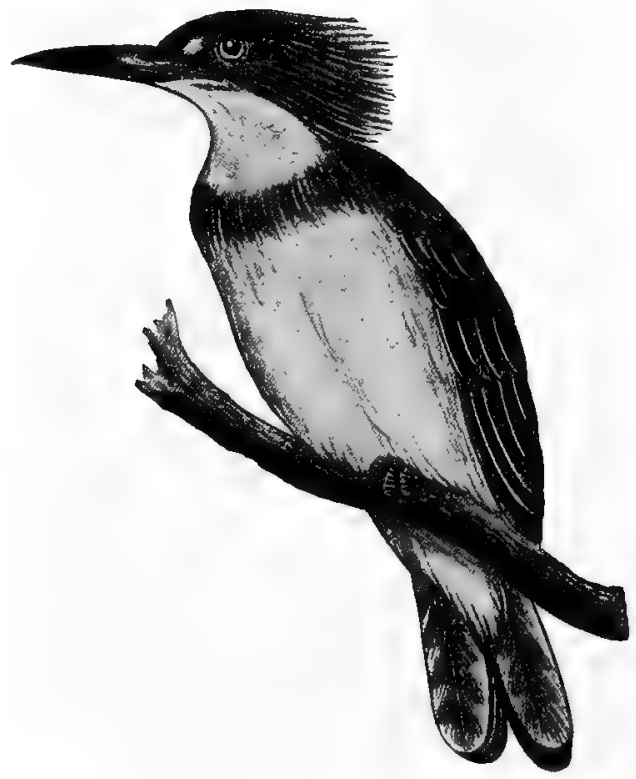

THE KING FISHER. [ONE-THIRD LIFE SIZE.]

"The ancients attribute to him, supernatural powers. It was supposed to construct its nest upon the waves, where it was made to float like a vessel at anchor. They believed that nature had gifted the sitting bird with the power of stilling the motion of the winds and waves during the period of incubation. 
Hence the name of Halcyon days from their name of the bird, Halcyon."

Miss Sweet recited the following poem that she had found somewhere although she did not know the author's name:

\section{THE KING FISHER.}

When midsummer sun burns fierce as flame

From dawn till eve in the sky,

Come down with me to the rocky vale

Where the river glides softly by

And under the shade of the willow trees

The fishes in quiet lie.

In the sleepy shadows that fringe the stream,

The horehound and woodbine spring,

And hid in the herbage green and cool,

There nestles a wondrous thing

That darts like a fairy arrow sped

On a green and azure wing.

His wing just ruffles the glossy wave,

As he skims o'er the placid stream,

Behold him, splendid in dazzling blue,

Lit up by the noontide beam!

If he would but stay! but he vanishes,

As swift as a passing dream.

Miss Sweet said: The lesson has been short, and we will defer the questions until we have listened to a story Laura has written about a bird which belongs to the same "order," as ornithologists say: 


\section{THE YELLOW-BILLED CUCKOO.}

All throligh the summer, about the dooryard, I had heard the hoarse kuk-kuk-kauk-kauk of the Cuckoo or Rain Crow, as he is sometimes called. He is said to call only before a rain, and has thus gained the name of "rain crow." This is not strictly true, for while the bird seemed to cackle more in the morning, just before a rain, he called many times when no rain immediately followed.

Although he seemed to be very near all the time, I could never get a sight of him. Every attempt was baffled by the thick foliage, until one morning a bird darted suddenly in at a window and out at the door.

I knew by its long tail and silent flight that it was the Cuckoo. Once after that I saw it drop quietly from a tree to the ground and pick at something in a slow, sleepy way. It remained some time upon the ground with wings slightly drooping and a sneaking expression in its whole attitude.

A few days after this it again dashed into the room, and striking against the door, fell to the floor. It fought furiously with its sharp curved bill when picked up from the floor. It was placed in a cage for further observation. The fall had stunned but not injured it, and I had a fine opportunity to note the delicate beauty of its olive gray plumage.

It had such a clean, velvet-like sheen that a queen might covet the dress it wore. Its long dark tail was 
tipped with white on its side feathers. Its breast and the downy feathers that drooped about its legs were grayish white.

I opened the cage door and it dropped to the ground. For an instant it erected head and tail until they formed a graceful $\mathrm{V}$, then it glided away in an upward curve, and was lost amid the leaves of the grapevine.

Since that I have seen it, a few feet away, with a large hairy caterpillar in its bill. Although so elusive in its habits, it seems to be very self-possessed when unexpectedly brought to view.

Let us recite in concert William Woodsworth's poem about

\section{THE CUCKOO}

O blithe new-comer! I have heard

I hear thee and rejoice!

O Cuckoo! shall I call thee bird,

Or but a wandering voice.

While I am lying in the grass

Thy twofold shout I hear;

From hill to hill it seems to pass,

At once far off and near.

Though babbling only to the vale Of sunshine and of flowers,

Thou bringest unto me a tale

Of visionary hours. 
Thrice welcome, darling of the spring,

Even yet thou art to me

No bird, but an invisible thing,

A voice, a mystery.

To seek thee did I often rove

Through woods and on the green;

And thou art still a hope, a love;

Still longed for, never seen!

And I can listen to thee yet;

Can lie upon the plain

And listen, till I do beget

That golden time again.

QUESTIONS.

We often read about "halcyon days." How is the expression connected with the Kingfisher?

Where can we find the Kingfisher?

Upon what does it feed?

Does it appear to enjoy its food?

Can it sing?

Does the Cuckoo sing?

Is there any resemblance between the Kingfisher and the Cuckoo?

Do you know how birds are classified? 


\section{BLUEBIRD.}

(Sia'lia si'alıs.)

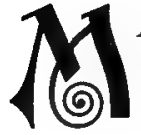

$\mathrm{ALE}$, rich azure blue; ends of wing quills, blackish. Throat and under parts chestnut. The blue sometimes extends around the head so that the chestnut is cut off from the bill. Length 6 to 7 inches.

Female, blue mixed with dull reddish brown, becoming bright and pure on tail and wings. Under parts paler with more rusty brown.

Smaller than male. Eastern United States and Canada. Migratory. Winters in southern States. Returns in early spring or mild winter weather.

Nest in hollows of trees, posts, or bird boxes; eggs four to six, pale, bluish, unmarked; two or three broods. They have a melodious song.

The reception of the pictures had been so flattering to "Artist" that he again incorporated the table in his picture. A Bluebird was perched on a gate post. The table was printed on a placard directly opposite the open gate. The design showed much more skill than any previous one and was greatly admired. Beneath the gate the following quotations were printed in colored chalk:

"The Bluebird balanced on some topmost spray, Flooding with melody the neighborhood."

H. W. LONGFELLOW. 
"The Bluebird shifting his light load of song, From post to post along the cheerless fence." JAMES RUSSELI LOWHIL.

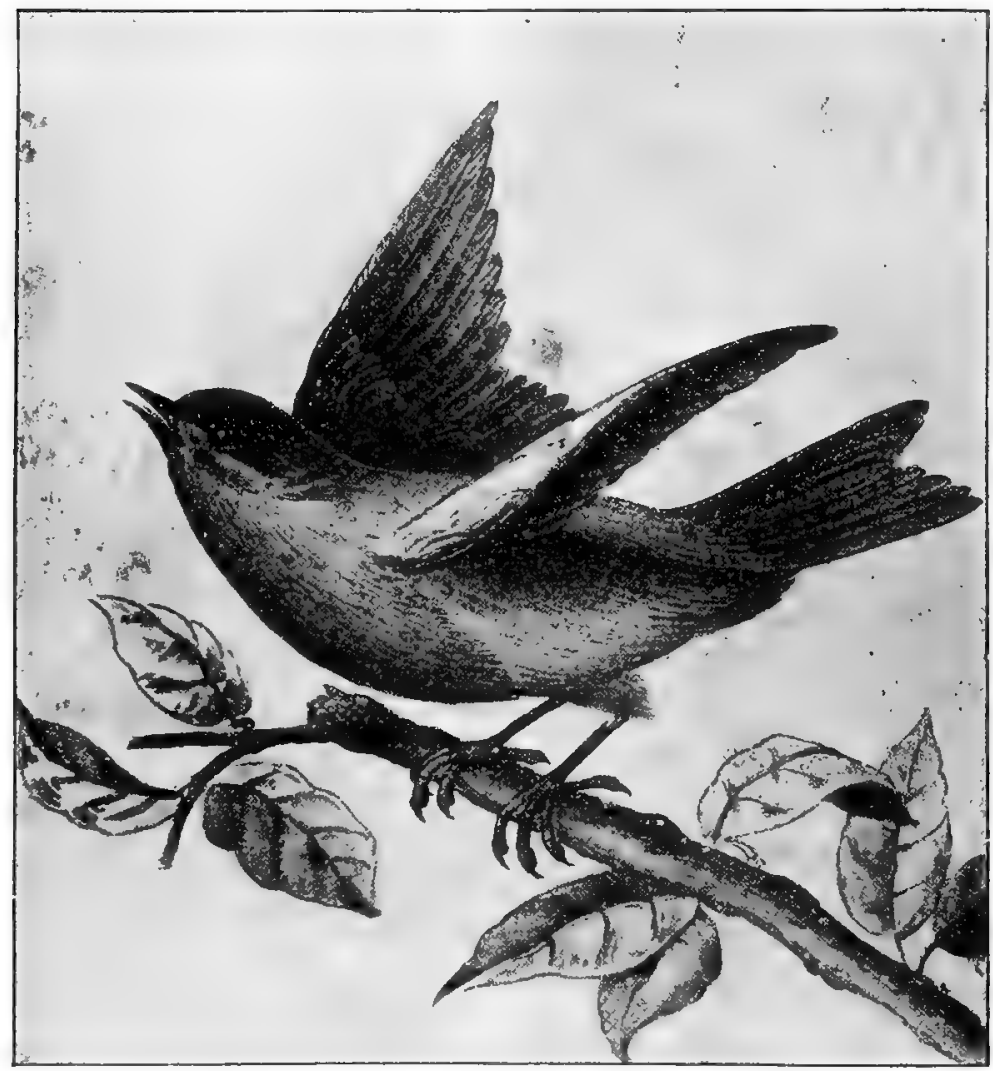

\section{BLUEBIRD.}

[ONE-HALF LIFE SIZE.]

Although the pupils in Miss Sweet's room had 
become enthusiastic bird lovers, it was not possible to have a full exercise every morning and almost before they knew it March had come. One night after school, the first week in March, Laura told her teacher that she was listening every day to hear the soft, plaintive notes of the Bluebird.

The next morning was sunny, and Laura, with rosy cheeks, brightened by her exercise in the "out doors" which she loved so well, came running into the school room saying "I heard a Bluebird. It said:

"Spring is coming, almost here,

Soon the violets will appear,

And the Robins bring good cheer,

Tru-al-1y, tru-al-1y, tru-al-1y."

Miss Sweet laughed and as the pupils quietly took their seats said: "If you will listen you may any of you hear 'tru-al-ly, tru-al-1y, tru-al-ly,' if you cannot hear all that Laura did. Where was the bird Laura?"

"I don't believe he was anywhere, unless he was in the clouds," said Laura. "I've watched and listened many times, but I've never yet seen the first Bluebird, and his voice seems to come from nowhere in particular."

The weather continued mild for several days and Laura soon reported that she had caught a glimpse of the bonny blue wings flitting about among the trees at home.

"Baby" said she saw one sitting on the post that 
holds the clothes line, gently lifting its wing and calling cheerily to its mate.

"Artist" observed that "the male bird wears the brightest colors," and Laura said "I learned when I 'was a little girl' (which made them all laugh) that the fashion in bird land was different from ours, for there the men always wear the prettiest clothes."

A whole week was spent on the Bluebird, and every day something new was reported.

The weather was still unusually pleasant for bleak and windy March, and Bluebirds could be seen everywhere, for many had arrived, and had already begun their yearly house hunting, and every pupil was able to report something new and interesting as the days went by. Some pairs would look about in a very inquisitive and inquiring manner, investigating every possible place for a nest, while others were quite saucy, and even quarrelsome, with their cousins, the Robins, who had begun to appear.

This state of things continued un-

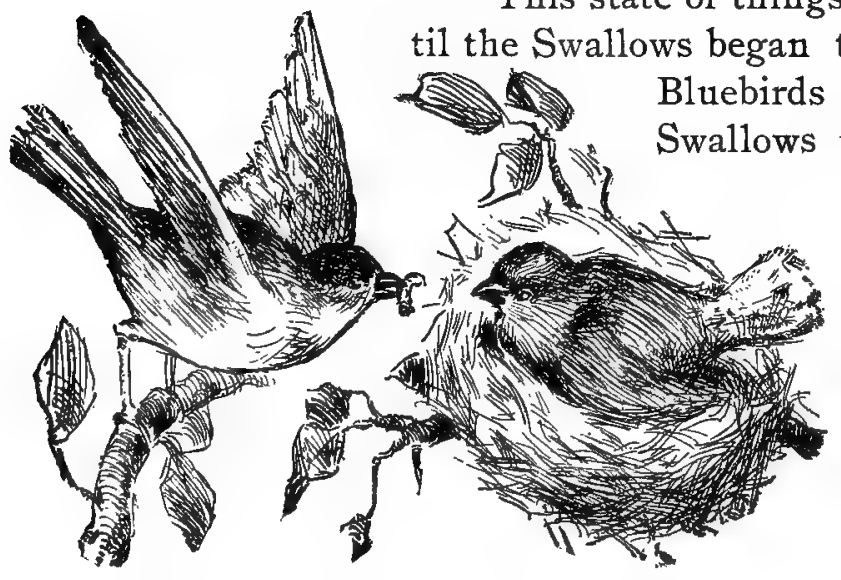


where our young students could not follow them. Laura told the following story about a pair of Bluebirds she observed last year:

"I discovered a pair of Bluebirds inspecting a toy basket which I had accidentally left in a tree the summer before. (Laura would like to be a bird herself, if she could, and sometimes chooses strange places for her play houses.) Mr. Bluebird was very much interested in the basket. He would alight on the edge or a twig near by, and call cheerily to Mrs. Bluebird. She was very slow in responding, and it was quite evident that she meant to have her own way in the matter. When, at last, she condescended to inspect it, and finally decided that it would be satisfactory, Mr. Bluebird was wild with delight, and away they both flew for material to build the nest. Mrs. Bluebird did all of the work, while he fluttered about and sang, but after she had brought the grass and placed it to suit herself, she waited while Mr. Bluebird would go in and look at it, and he would come out exclaiming 'tru-al-ly lov-ee-ly.' (At least that is what Laura said, and she was there.)

"Soon the nest was completed, and six pale blue eggs were found in it. Now Mrs. Bluebird never left the nest, and Mr. Bluebird fed her regularly and cheered her by his pleasant songs until the little birds came. He was a devoted husband as long as I watched them, but, when the Robins began to build their nest close to the house, I forgot them for a few days, and, 
when I went to look again, they had moved out and taken their family with them."

Miss Sweet recited J. Russell Taylor's verses about the Bluebird, and other poems were recited by the pupils :

Ere yet the fields were green with winter wheat, Before I thought to see the earliest bird, In the unbudded maple tops I heard

The Bluebirds' jubilant gossip, low and sweet, And full of bubbling merriment discreet Withheld from perfect utterance, for fear

The cold should rage again, if he should hear, With all his whining winds and icy sleet, And snow the orchard full of mocking bloom, Round their blue wings. Seductive was their glee, So I was glad at heart to list to these Elusive voices, bodiless ecstasy, And delicate tinklings from old withered trees That marked the term of winter and his doom.

\section{THE FIRST BLUEBIRD OF SPRING.}

BY GILBERT S. EVERHART.

Hark! hark! I hear a Bluebird sing!

His voice rings through the purple air, And tells me that the hand of spring

Is weaving garlands fresh and fair, In mossy dell, or frowning fell, And strewing blossoms everywhere. 
OUR FRIENDS, THE BIRDS.

What lesson doth the springtide teach, As from the mould the blooms arise! How life begun below shall reach

Eternal life beyond the skies;

These souls of ours, in blissful hours, Bloom ever in God's Paradise.

\section{A BAND OF BLUEBIRDS.}

(In Autumn.)

By WM. H. Hayne.

Oh, happy band of Bluebirds, Brave prophets of the spring, Amid the tall and tufted cane,

How blithesomely you sing! What message haunts your music

'Mid Autumn's dusky reign! You tell us nature stores her seeds

To give them back in grain.

Your throats are gleeful fountains

Through which a song-tide flows, Your voices greet me in the woods,

On every wind that blows!

I dream that heaven invites you

To bid the earth "Good-bye;"

For in your wings vou seem to hold

A portion of the sky!
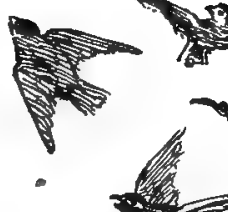

T)

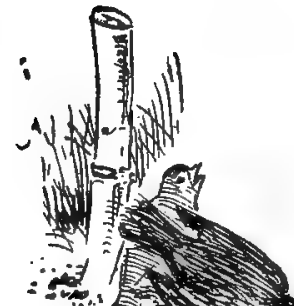

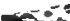
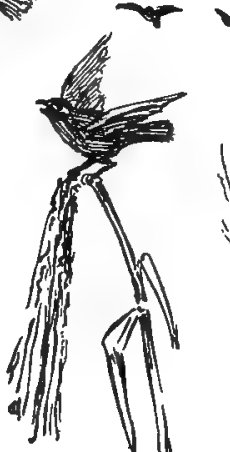
To flit across the fading fields

And glorify the grain.

You leave melodious memories,

Whose sweetness thrills me through:

$\mathrm{Ah}$ ! if my songs were such as yours,

They'd almost touch the blue!

\section{BLUEBIRD.}

BY MAURICE THOMPSON.

Short is his song, but strangely sweet

To ears aweary of the low,

Dull tramp of Winter's sullen feet,

Sandalled in ice and muffled in snow.

Short is his song, but through it runs

A hint of dithyrombs yet to be,-

A sweet suggestiveness that has

The influence of prophecy.

Miss Sweet wrote upon the blackboard the following lines by Frank Dempster Sherman, which the pupils copied into their note books on the page preceding the table, together with the lines which the artist had placed after the table on the blackboard.

"Born of the azure skies,

His wings betray his birth;

Earthward with song he flies,

So Heaven comes to earth." 


\section{QUESTIONS.}

How early in the spring have you seen a Bluebird? Was it alone or in a flock?

Which is prettier, the Bluebird or Bluejay?

Is it a sweet singer?

Where does it build its nest?

Did you ever see the Bluebirds and Martins trying to get the same birdbox?

Do you see many Bluebirds about your home?

Does the Bluebird ever stay about your home all winter?

Have you read many things about it?

Can you tell some story or repeat some poetry you bave read about it?

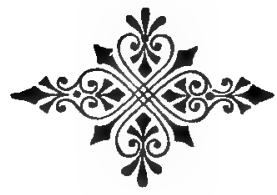




\section{THE ROBIN.}

(Turdus migratorious.)

PPER parts slate color with a shade of olive. Head black; the eyelids, and a spot before the eye, white; the throat, streaked with white. Quills of the wings dusky. Tail blackish, outer feathers tipped with. white. Under parts and wing coverts chestnut. Bill yellow with dusky tip.

Eyes dark brown; feet, blackish. Length about 10 inches. Extent 16.

Female similar but colors duller. Throat with more white. Bill much clouded.

An abundant and familiar bird throughout North America. Migratory.

Nest in trees, usually saddled on a horizontal bough; composed of mud and grasses. Eggs four to six, greenish blue.

Laura came down to breakfast one morning with her eyes shining, and quite forgetting the usual salutation said: "I know it is truly spring, for I heard a Robin singing before I woke up."

Of course the family laughed, but many a lover of birds has been awakened by a Robin's sweet notes and felt as though it had been singing a long time, as indeed it doubtless had. The Robin, even for a bird, is an early riser and welcomes the sun with his cheery song, that seems almost like an anthem of praise. In the nesting season his voice can be heard all day, but 
it seems especially sweet in early morning and at sunset.

Laura reached school very early as she wanted to report having heard a Robin, but she found that the artist had been there before her. Printed in red, white

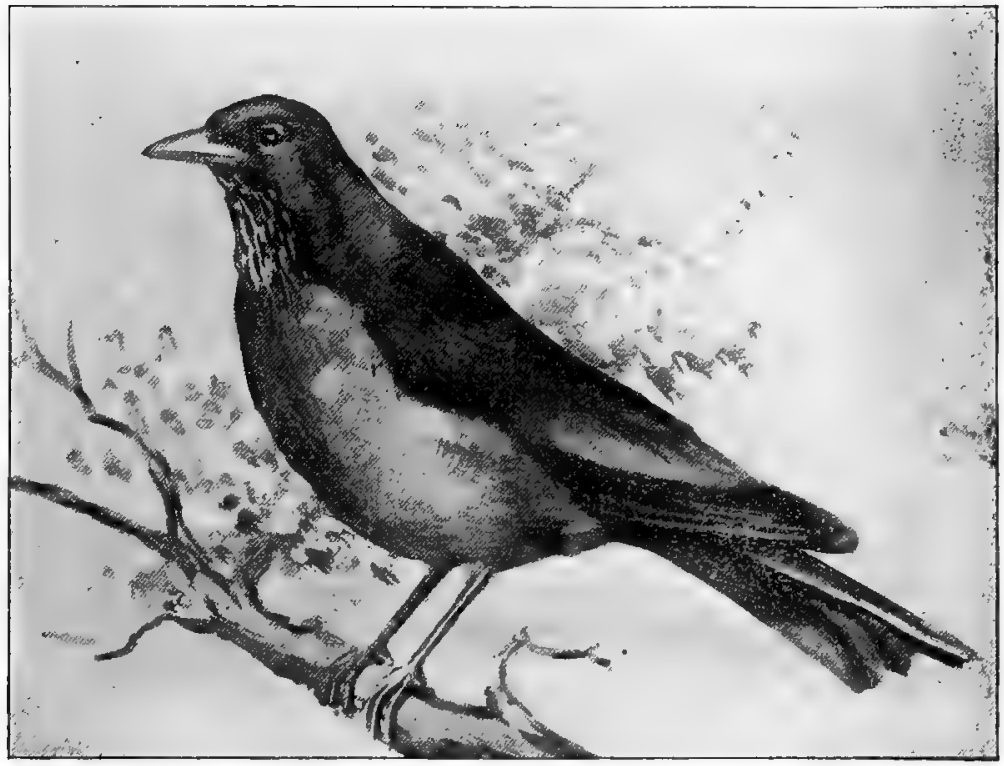

ROBIN.

[ONE-HALF IIFE SIZE.]

and blue fancy letters at the top of the blackboard were the following lines:

"The world were sad without thee,

Oh my friend;

Sing still your love so sweet, your joy so calm, 
To every care thy warbling gives an end To every wound of woe 'tis healing balm."

DaNIEL S. DONOHUE.

"The sweetest sound the whole year round

'Tis the first robin of the spring;

The song of the full orchard choir

Is not so fine a thing."

Edmund Clarence Stedman.

Beneath the lines was a wide lawn, the grass show: ing green here and there, where a Robin had alighted and with his head on one side was peering about, while his mate watched him from a branch of a tree near by.

The table formed no part of the picture this morning, but was left where it had been written the night before.

The pupils marched gayly to their seats singing "Robin, Robin Redbreast." As soon as they were seated one of their number was appointed to read the questions, of course awaiting the answers each time.

The answers came quickly, for the Robin is a bird familiar to everyone, as it likes to build its summer home near the homes of men. There is no bird except the English Sparrow that is more common, for it can be found in every garden and orchard in New England and all the northern states of this continent. It is one of the earliest comers in the spring and is among the last to leave in autumn. It can often be seen early in March and frequently remains all winter when the 
weather is mild. Laura told the following story about a pair of Robins that she had observed:

"Last summer I speńt many happy hours watching a pair of Robins that had built their nest in a large oak tree whose branches almost touched my chamber window. I happened to see them when they alighted on a branch in plain sight and began talking about the April weather. I soon found they were searching for a place for their nest, and I saw them bring grass and mud and attach it carefully to a horizontal bough they had selected as a safe place. It was interesting to watch them, but I was disappointed that they were satisfied with so rough a house. Mr. and Mrs. Robin were very pretty lovers, and as they belong to a musical family I supposed they would have the artistic temperament, but I found that they were not even good artisans. My mother and aunt said that they considered them very noisy neighbors, and they told me one day that they thought they were quarrelsome, but they never seemed to make harsh noises unless something outside of their family relations troubled them, so I did not mind their noise although they were always talking.

"One morning I discovered that by leaning out of my window I could look right into the nest, and I saw four beautiful greenish blue eggs. I found out then why my best dress is called Robin's egg blue. After this I never left my room in the morning without peeping into the nest, but one morning Mrs. Robin must 
have thought me too inquisitive, for she flew at me and gave me a sharp tap on my head. I was so frightened that I nearly fell out of the window, and after that I carried on my observations at a more respectful distance, and did not try to invade the privacy of her home, although I thought them interesting neighbors and found out something new every day.

When the eggs were hatched Mr. and Mrs. Robin were obliged to work very hard to support their family, for it did seem as though the little birds were all mouth, and lived for the purpose of getting something to eat. Auntie and I watched them one morning for a little while and those birds brought every three minutes some worms or insects for those open mouths. It was perfectly wonderful, and after that I never much believed in their stealing many cherries or berries for I cannot see how they had time. After awhile the little birds began to get out of the nest, and the old birds would sit on a branch and call to them. One little bird tumbled out and I was just in time to rescue it from the cat. I carried it up stairs
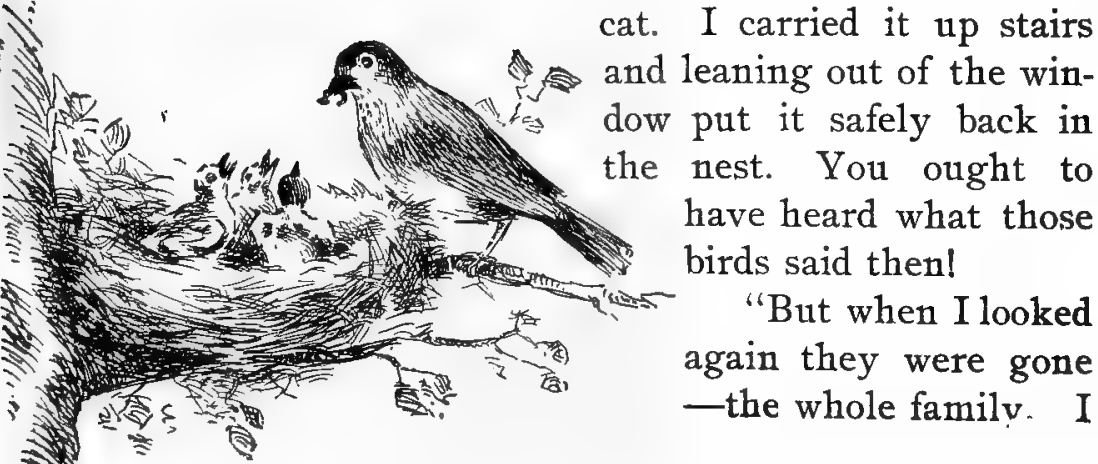
the nest. You ought to have heard what those birds said then!

"But when I looked again they were gone -the whole family. I 
didn't see much of Robins after that, as I was interested in other birds, until last January when I saw a whole flock of them in our garden. There are three large cedar trees close together in one corner and although the weather was very cold, the birds seemed to be very happy and comfortable. I think if we would notice more carefully we could frequently see these flocks in winter."

Miss Sweet said, "Some writers about the Robin think that he has not been noticed much in song or story. Now we will see what you have found."

The following selections were then read by the different pupils who had found them. None of them are very commonly known:

\section{WELCOME TO THE FIRST ROBIN.}

By Benjamin Copeland.

Herald of the happy year,

Robin red-breast sit thou here;

Welcome to thy destined goal,

Welcome, songster of the soul.

Age and childhood find in thee,

Kindred bond of sympathy;

Hope and memory are one,

In thy song's sweet unison.

Common freehold all hearts claim,

In thy nature's artless aim; 
Best of priests and poets, thou, Sitting on the leafless bough.

Mead and mountain wood and wold, Wait the rapture manifold;

Which shall prove thee saint and seer,

Dearest minstrel of the year.

Glows the mold with vernal fire,

Kindled by thy love's desire;

Nature wakens at thy call, To her annual festival.

Every note like April rain, Thou transmutest in thy strain;

With the season's subtle power, Winter's dearth or summer's dower.

Matchless messenger divine, Peerless privilege is thine; Thou interpretest to faith, The deep mystery of death.

\section{THE SAME ROBIN.}

By Celia ThaXter.

Don't you remember his glowing red breast

And his olive brown coat and his shining black eyes, How he works for his dinner and watches his nest, A citizen sober and happy and wise! 


\title{
THE FIRST ROBIN.
}

\author{
BY J. F, HERBIN.
}

A Robin came to-day with earliest dawn, And whistled through the orchard avenues,

Birdless and bare, and dull with clinging dews.

From tree and shadowy fence the plumage shone

Of this sole singer; while through lane and lawn

He called in vain for answer to the news

He brought to-day among the misty views

Until his whistle and his wing were gone.

The piping said not whence or why he came

Before a bud is broken on a tree,

While yet the brooks are icy, and the cold

Clings to the earth. His breast was like a flame.

In the dull morn; his calling seemed to be

For life, not yet awake in field and wold.

\section{THE ROBIN.}

BY MARCELLA A. FITZGERALD.

Among the quiet peasants of Brittany they tell

This legend of the Robin by children loved so well;

This legend of the Robin, whose merry accents ring

Through every glade and covert sweet welcome to the Spring.

They say that when the Savior to Calvary's rugged crest Bearing his cross moved forward, sore, wounded and oppressed, When foemen thronged around him, and friends fled far in fear, Above the angry multitude a Robin hovered near. 
And reckless of the tumult and angry cries of scorn, From out Christ's bleeding forehead it snatched one cruel thorn; Then o'er the Robin's bosom the sacred blood flowed down, And with its ruby tintings dyed the plumes of russet brown.

And evermore the sweet bird bore upon its tender breast The warm hue of the Savior's blood, a shining seal impressed. Hence dearest to the peasant's heart, 'mid birds of grove and plain, They hold the Robin, which assayed to soothe the Savior's pain.

\section{A SEPTEMBER ROBIN.}

BY MISS MULOCK.

My eyes are full, my silent heart is stirred

Amid these days so bright

Of ceaseless warmth and light; .

Summer that will not die,

Autumn, without one sigh,

O'er sweet hours passing by-

Cometh that tender note

Out of thy tiny throat,

Like grief, or love, insisting to be heard

O little plaintive bird!

No need of word.

Well know I all your tale, forgotten bird!

Soon you and I together

Must face the winter weather,

Remembering how we sung

Our primrose fields among,

In days when life was young;

Now all is growing old

And the warm earth's a-cold,

Still with brave heart we'll sing on, little bird !

Sing only. Not one word. 
The girls recited in concert the following lines by Bryant :

Upon the apple-tree where rosy buds

Stood clustered, ready to burst forth in bloom,

The Robin warbled forth his full, clear note

For hours, and wearied not.

\section{And the boys these by Lowell:}

The sight of thee calls back the Robin's song

Who from the dark old tree

Beside the door, sang clearly all day long,

And I, secure in childish piety,

Listened as if $I$ heard an angel sing

With news from Heaven, which he did bring

Fresh every day to my untainted ears,

When birds and flowers and I were happy peers.

Miss Sweet said she enjoyed Charles H. Lüder's verses, which she recited:

In country lanes the Robins sing,

Clear-throated, joyous, swift of wing.

From misty dawn to dewy eve

(Though cares of nesting vex and grieve)

Their little heart-bells ring and ring.

And when the roses say to Spring

"Your reign is o'er," when breezes bring

The scent of spray that lovers weave

In country lanes. 
The Red-breast still is heard to fling

His music forth; and he will cling

To Autumn till the winds bereave

Her yellowing trees, nor will he leave

Till winter finds him shivering

In country lanes.

Miss Sweet. said: "Our Robin, although not neglected, is not so celebrated in song as the English Robin Red-breast, who is no relation. Our Robin belongs to the Thrush family, and some of his cousins are celebrated singers. We have given a good deal of time to the Robin, but he is such a cheery, neighborly bird he is worthy of it. Next year, may-be, we will each have a story to tell about Mr. and Mrs. Robin."

QUESTIONS.

Do you like the Robin's song?

Is the Robin a sociable bird?

Do you know any of his cousins?

Does the Robin belong to a musical family?

Do you know Longfellow's lines beginning " $\mathrm{My}$ old Welsh neighbor over the way"?

Where does the Robin spend the winter?

Tell a story of your own about the Robin? 


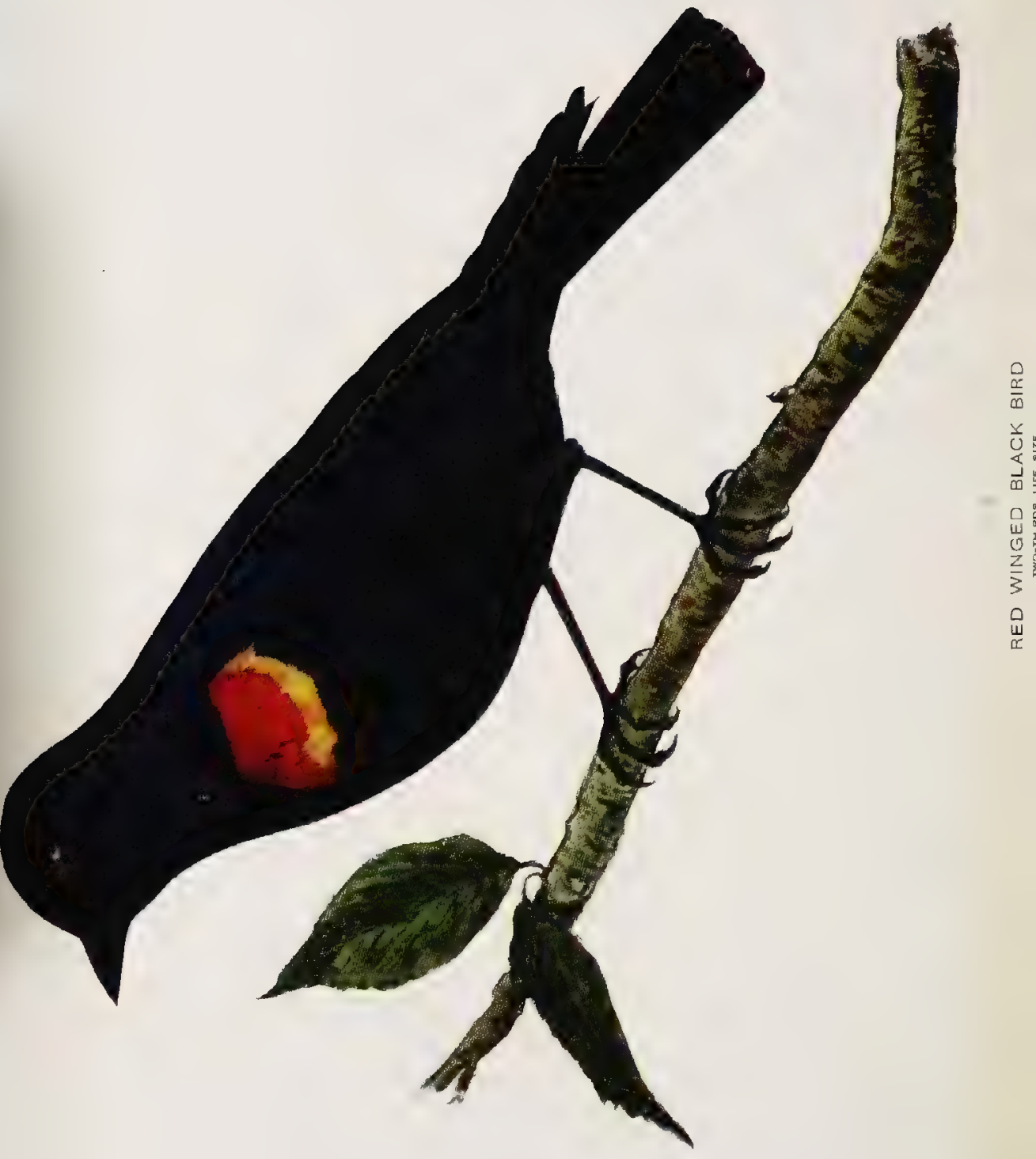




\section{RED-WINGED BLACKBIRD.}

\section{(Agelac'us phoeniceus.)}

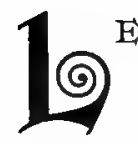

ESSER wing coverts scarlet like arterial blood, bordered with brownish yellow. Males, a lustrous black. Females everywhere streaked; above, blackish brown with pale streaks; below, whitish, with many sharp dusky streaks. Sides of head, throat, and bend of wing, tiuged with reddish.

Temperate North America chiefly east of Rocky Mountains. Breeds everywhere in its range.

In August and September collects in immense flocks.

Nest usaally in reeds or bushes near the ground; occasionally in vines or small trees. Eggs, four to six, pale blue marked with brown. Note a guttural chuck.

"Most of our information concerning the Red-wing Blackbird," Miss Sweet began, must be obtained from books, as city children have small opportunity for observation of the habits of these birds. They are always seen in large flocks. They have practically no home life, but are like the folks who live in large hotels and spend as much time as possible in having a good time. Although the birds do take time to build their nests and rear their young.

"They suspend their nests somewhat like the Orioles, and are almost as dextrous. Instead of selecting the highest trees for their homes, as the Orioles do, they prefer to fasten them to a tuft of reeds, or to 
bushes in a low, marshy place. The nests are bound. securely to the uprig.it stems, sometimes by the leaves of the plant to which they are attached.

"They rear but one brood in a year after which they collect in great flocks.

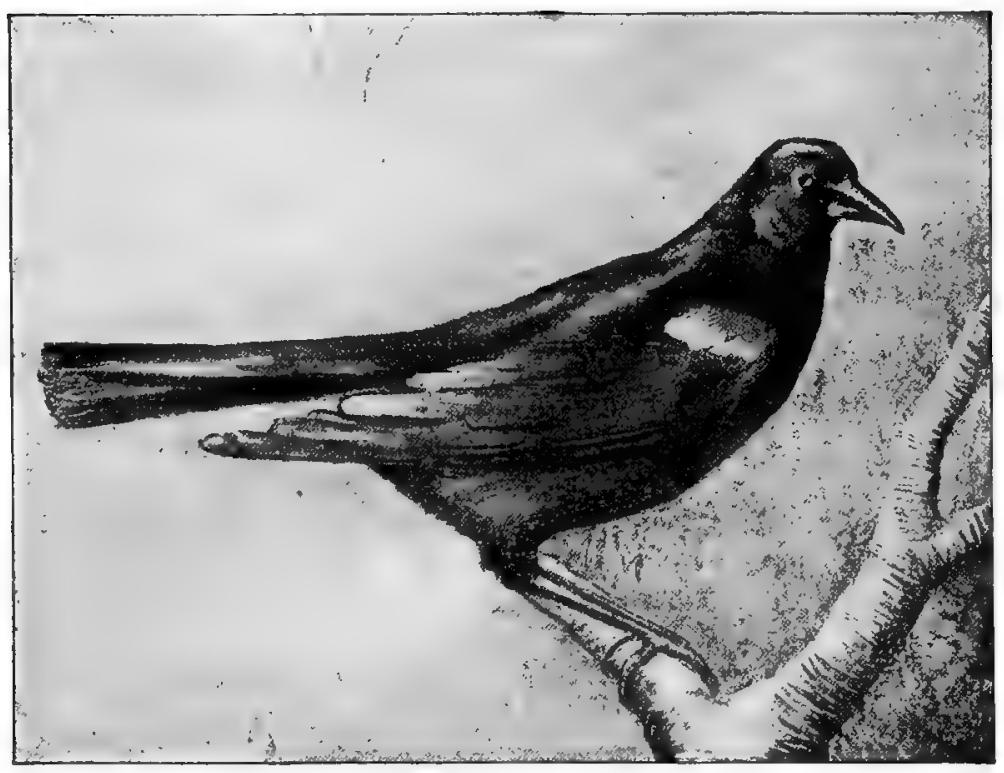

RED-WING BLACKBIRD.

[ONE-BALF LIFE SIZE.]

"In the south they do much damage to the corn crops. In the north, where they are not so numerous, they cannot do so much harm and in destroying grubs do much good. 
"Their notes are sharp, but cheery, and when heard at a distance, or when the birds seem to chant in chorus, there is something inspiring in the sound that once heard can never be forgotten. The Red-wing belongs to the same family as the Bobolink, Oriole, Cowbird, Purple Grackle and Meadow Lark.

"I have selected a poem by Ernest McGaffey, who extols their musical ability."

\section{THE RED-WING.}

On a bulrush stalk a Blackbird swung

All in the sun and the sunshine weather,

Teetered and scolded there as he hung

O'er the maze of the swanp-woofs tangled tether,

And the spots on his wings were red as fire,

And his notes rang sweet as Apollo's lyre.

The summer woods were a haze of blue,

Draped and robed with an emerald kirtle, And the Blackbird whistled clear and true,

Till the Thrush was mute in the flowered myrtle; And the spots on his wings were red as fire, And his notes rang sweet as Apollo's lyre.

A black bass leaped for a dragon-fly

And struck the spray from the sleeping water, While airily, eerily, there on high

Sang the Blackbird pert from his teeter-totter. And the spots on his wings were red as fire And his notes rang sweet as Apollo's lyre. 
A fig for the music born of man;

I shake my head, and I doubt me whether

Your cultured strain has a charm for Pan

When a Blackbird sings in the sunshine weather, With the spots on his wings as red as fire, And his notes as sweet as Apollo's lyre.

\section{QUESTIONS.}

Have you ever seen a flock of Red-wing Blackbirds?

Do they build as pretty a nest as the Oriole?

Why do they build in a marsh?

What is their food?

To what other birds are they related?

Which do you think prettier, the Red-wing or the Grackle?

Have you read Alice Cary's Story of a Blackbird? Or 'Tennyson's lines to $A$ Blackbird?

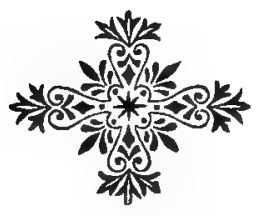




\section{KILDEER PLOVER.}

(Agia'lites voci'feros.)

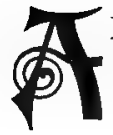

BOVE grayish brown with an olive shade, and sometimes a slight bronzy lustre. Tail coverts from orange brown to chestnut. Forehead with a white band from eye to eye, and a black band above it. White collar and throat. Black collar continuous with black pectoral band. The foreparts are encircled with a complete black ring, behind which is a black half ring.

A white stripe over and behind eye. Under parts white. Eye black with a bright ring around it. Length 9 to 10 . North America breeding anywhere. Somewhat migratory. A noisy bird with a shrill whistle.

Nest in grass or near water. Eggs four, drab or creamy, marked with brown.

"Laura's 'table' describes the Kildeer only, but we will take up the Woodcock and the Snipe also in this lesson. Perhaps a slight comparison of these birds may better enable us to know them if we ever have an opportunity to observe them," Miss Sweet remarked as the pupils were taking their seats.

As soon as they were ready for work, she said: "This bird is a small American Plover, which, on on account of its shrill call, is in some parts of this country known as the Kildeer, and in other parts the Kildee. It is very common about water courses and marshy places. It is amusing to see them run about in the mud, on their long, slender legs, in search of 
food. They run so fast that one cannot help laughing at their haste. They also fly with great swiftness. Their shrill cry of 'Kil-deer, kil-deer' is almost startling when they utter it as they suddenly take wing.

"They migrate to great distances, and are among the earliest of spring travelers. The young are able to run about and leave the nest almost as soon as hatched. Another shore-bird nearly related to the Kildeer is

\section{THE WOODCOCK.}

"It differs from the Plover in having a longer bill, and the eye placed far back and high up, with the ear below. "Dr. Coues says: 'If the brain be examined, it will be found curiously tilted over so that its anatomical base looks forward.' Again, he says, 'They are knowing birds, if their brains are upset, and their successful pursuit calls into action all the better qualities of a true sportsman.'

"My only experience in hunting Woodcock was quite successful. Finding one in my garden one morning among the corn, I simply walked after it and picked it up. It resented being caged by thrusting its long bill through the wires until it made its head bleed. This seemed cruel, so it was taken back to its 'native heath' and released.

"One peculiarity of the Woodcock is its habit of carrying its young from place to place in its feet. It is nocturnal in its habits, remaining concealed during the day and coming out at twilight to find food. 


\section{THE SNIPE.}

"The habits of the Snipe are somewhat similar to those of the Woodcock. Legs and bill somewhat longer in the Snipe. Audubon says of them: "The birds are met with in the meadows and low grounds, and by being on the spot before sunrise you may see both male and female mount high in a spiral manner, now with continuous beats of the wings, now in short sailings, until more than a hundred yards high, when they whirl round each other with extreme velocity, and dance, as it were, to their own music; for at this juncture, and during the space of four or five minutes, you hear rolling notes mingled together, each more or less distinct, perhaps, according to the state of the atmosphere. The sounds produced are extremely pleasing, though they fall faintly on the ear. We have so little time this morning that $I$ have hastily described them that you may have more time for discussing the questions."

\section{QUESTIONS.}

In what do these three birds resemble each other?

How does the Plover differ from the others?

Do they all feed alike?

Have you ever seen them?

Where?

At what time of day?

What can you tell about them?

Can you find anything in literature concerning these birds? 


\section{SONG SPARROW.}

\section{(Melospi'za fascia'ta.)}

ELOW white, shaded with brownish, with numerous
black-centered, brown-edged streaks across breast, and
along the sides. Throat white. Crown dull bay with
black streaks.

Wings with dull bay markings. Tail brown with darker shaft lines. Usually a blotch on breast. Bill dark brown; feet, pale brown. Length 5.90 to 6.50. Female similar in size, form and color.

Eastern United States and Canada. Winters nearly throughout its range. A common winter sparrow of the Middle States.

Nest in bush or on ground. Eggs four to six, greenish white with brown, lavender or purple markings. Two or three broods may be raised. A hearty, sunny songster.

As soon as the pupils were seated they began to recite in concert Henry van Dyke's beautiful poem:

\section{A LITTLE BROTHER OF THE AIR.}

There is a bird I know so well,

It seems as if he must have sung

Beside my crib when I was young;

Before I knew the way to spell

The name of even the smallest bird,

"His gentle, joyful song I heard.

Now see if you can tell, my dear,

What bird it is that, every year,

Sings "Sweet-sweet-sweet-

very merry ckeer." 
He comes in March, when winds are strong,

And snow returns to hide the earth;

But still he warms his heart with mirth

And waits for May. He lingers long

While flowers fade; and every day

Repeats his small contented lay;

As if to say, we need not fear

The season's change if love is here

With "Sweet-sweet-sweet-

very me:ry cheer."

He does not wear a Joseph's-coat

Of many colors, smart and gay;

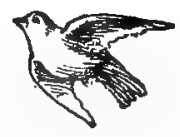

His suit is quaker brown and gray With three dark patches at his throat.

And yet of all the well-dressed throng

Not one can sing so brave a song;

It makes the pride of books appear

$A$ vain and foolish thing, to hear

His "Sweet-sweet-sweet-

very merry che'r."

A lofty place he does not love,

But sits by choice and well at ease,

In hedges, and in little trees

That stretch their slender arms above

The meadow-brook; and there he sings

Till all the field with pleasure rings; And so he tells in every ear, The lowliest home to heaven is near

In "Sweet-sweet-sweetvery meryy cheer."

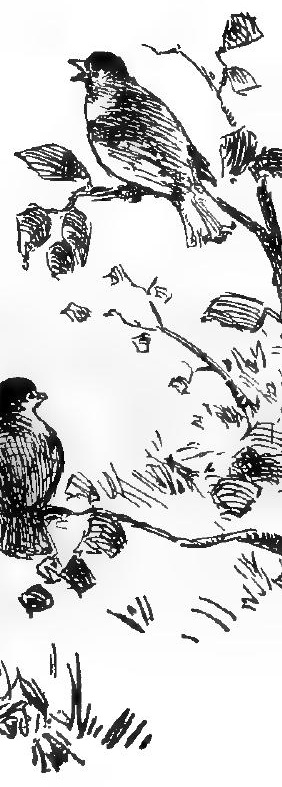


I like the tune, I like the words;

They seem so true, so free from art,

So friendly, and so full of heart,

That if but one of all the birds

Could be my comrade everywhere,

My little brother of the air,

I'd choose the Song Sparrow, my dear,

Because he'd bless me every year,

With "Sweet-sweet-sweet-

very merry cheer."

This was a surprise to Miss Sweet. She was delighted with the selection, the excellence of the recitation and the spirit which prompted the pupils to learn the poem.

"I think the Song Sparrow is a cute little bird, don't you, Miss Sweet?" said "Querist."

"He is a great favorite with me, and I think is almost as well known as the Robin and Bluebird, both on account of his early arrival and sweet song."

"I wish he was not so timid," said "Baby." "The Hair Bird will come close up to the steps for crumbs but the Song Sparrow is too shy."

"I saw one yesterday in the public garden," said a boy who had recently moved from Boston, "and he was singing as loud as he could. I was surprised, it is so early."

Several of the pupils had heard them, as they had begun to arrive in large numbers, and some of the birds were already beginning to seek a good place for a nest. Laura said: "Last year a pair built their nest in a 
flowering currant bush in one corner of our garden. I happened to discover it, but they were so shy I never dared go near the nest for fear they would leave it. I looked up their habits in several books and found that they rear two and sometimes three broods in a single season. The male bird sings until the last brood leaves the nest."

"Querist" asked: "Have you ever noticed how neat and pretty our little friend looks beside the English Sparrows?"

"Baby" said: "I know him by his striped vest, and the blotch on his breast, as well as by his light brown color."

"I call him a prophet," said Laura, "because he comes so early, and his cheerful notes are among the first of spring's messages, even when snow has not yet disappeared."

"I have often seen one in the winter," remarked "Artist."

"He is a great favorite with the poets," said Miss Sweet. "Sometimes I think that he must be a poet himself, in Bird land, for there is no other bird who has such wonderful variations in song, and his voice may be heard from March through October. I will recite Lucy Larcom's sweet verses concerning him."

Sunshine set to music!

Hear the Sparrow sing!

In his note is freshness

Of the newborn spring; 
In his trill delicious Summer overflows-

Whiteness of the lily, Sweetness of the rose.

Pilgrim of the treetops, Burdened with a song

That he drops among us

As he flies along.

Promises and blessings

Scattered at our feet,

Till we sing together,

" Oh, but life is sweet!'

Waft us down faith's message

From behind the sky,

Till our aspirations

With thee sing and fly!

"God is good forever!

Nothing shall go wrong!"

Sunshine set to music-

'Tis the sparrow's song.

The following selections were read by different members of the class:

\section{-THE SONG SPARROW.}

BY EDWARD W. THOMPSON.

When plowman ridge the steamy brown,

And yearning meadows spread to green, And all the spires and towers of town,

Blent soft with wavering mists are seen; When quickened woods in freshening hue 
With bursting buds begin to swell, When airs caress and May is new,

Oh, then my shy bird sings so well!

Because the blood-roots flock in white,

And blossomed branches scent the air, And mounds with trillium flags are dight

And dells with violets dim and rare; Because such velvet leaves unclose,

And newborn rills all chiming ring, And blue the sun-kissed river flows-

My timid bird is forced to sing.

$A^{\prime}$ joyful chorus lilted clear-

Four notes-then falls the frolic song, And memories of a vanished year

The wistful cadences prolong;

"A vanished year- $\mathrm{O}$, heart too sore-

I cannot sing; " thus ends the lay;

Long silence, then awakes once more

His song, ecstatic of the May!

\section{THE SPARROWS.}

The Sparrows are interpreters

Unto this heart of mine

Of love beyond all human thoughts

My Father's love divine.

For not one falls without his care,

Yet Christ died not for them!

$O$ timid heart it is thyself

That dares thyself condemn. 


\section{SONG SPARROW.}

BY GEORGE PARSONS LATHROP.

Glimmers gray the leafless thicket

Close beside my garden gate, Where so light, from post to picket, Hops the Sparrow, blithe, sedate; Who with meekly folded wing, Comes to sun himself and sing.

It was there, perhaps last year,

That his little house he built;

For he seems to perk and peer,

And to twitter too, and tilt

The bare branches in between, With a fond, familiar mien.

Once, I know there was a nest, Held there by the sideward thrust Of those twigs that touch his breast;

Though 'tis gone now. Some rude gust

Caught it. over full of snow,Bent the bush and robbed it so.

Thus cur brightest hopes are lost

By the restless winter's wind, When, with swift, dismantling frost

The green woods we dwell in, thinned

Of their leafage, grow too cold For frail hopes of summer's mold. 
OUR FRIENDS, THE; BIRDS.

But if we, with spring days mellow,

Wake to woeful wrecks of change,

And the Sparrow's ritornello

Scaling still its old sweet range;

Can we do a better thing

Than, with him, still build and sing?

QUESTIONS.

Have you heard a Song Sparrow this year?

Have you seen one?

Do you know him from Chippie, the Hair Bird?

When does he come to the north?

Where does he build?

What kind of nest?

How many nests in one year?

Do they ever raise two broods in one nest?

Have you ever seen one in winter?

Is he one of the poet's favorite birds?

Where do you find this from Lowel1: "A week ago, the Sparrow was divine?"

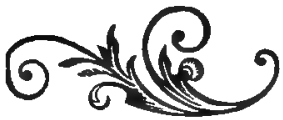




\section{BARN SWALLOW.}

\section{(H. erythrogas'tra horreo'rum.)}

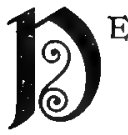

EEP lustrous steel blue; forehead and under parts, rufous; an imperfect steel blue collar. .Wings and tail, blackish, with steel blue or greenish gloss. The lateral pair of tail feathers much lengthened and filiform at the end; all but the central pair, with a white spot. Length, 6 to 7 inches. Tail, 3 to 5 inches; the fork, 2 to 3 inches deep. Female similar, but somewhat smaller. Throughout North America.

They build a nest of mud similar to the Robin's nest, but lined with feathers, in barns, outhouses, or under the eaves and under cliffs of rocks.

Eggs, nearly white with fine spots of purple.

"Artist" had again visited the school-room at an early hour and put upon the blackboard a picture he called "The flight of the Swallows." Underneath he had written these lines by William Cullen Bryant:

"There are notes of joy from the Hang-bird and Wren, And the gossip of Swallows through all the sky."

As Miss Sweet called attention to the picture, she said, "We have often enjoyed the work of "Artist's" pencil, but do not hear much from him in class, so I asked him to write something about the Swallow, to read to us this morning. He must be a close observer or he could not make good pictures." 


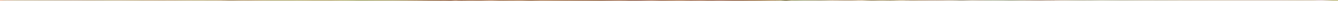



OUR FRIENDS, THE BIRDS.

"Have you ever visited an oldfashioned barn? How cool and pleasant it seems as we enter its great wide doors on a summer day! Here are stalls for the horses, sheds for the cattle, great bins of yellow corn, the wagons, the carriage and, over in that corner, the sleigh. Above is the wide haymow, where Biddy hides her nest, and away up among the rafters the Swallows have their mud-built homes. The man who built this barn cut holes in the gable endsfor ventilation, perhaps, but the Swallows use them for doors. How patiently they have worked to carry the clay and fasten it to the beams, then the grass and feathers to line it.

"What a busy throng they are, chattering, twittering, catching insects, flying in and out on tireless wings, finding in the old barn their "city of refuge" from heat and storm.

"I have often lain on my back on the hay in my grandfather's barn and watched them build their nests of mud and straw, carrying in at last a few feathers to make a soft nest for their birdlings. I have listened to their low chattering, wondering what they were saying to each other, and sometimes I would hear 
104 OUR FRIENDS, THE BIRDS.

a clear, sweet note that was like the ending of a song. It always seemed to me as though they were all too busy to really sing, but a single note which ended their chattering was like a glad exclamation of praise for the joy of living.

"I have watched them flying over the pond behind the barn, back and forth, as though they were chasing each other. I found out afterward that this is the way they get their food.

"I have counted from twenty to twenty-five nests on the rafters in grandfather's barn, and I used to call it the 'Swallows village.' I have frequently seen a half dozen birds sitting out on the little platform against their nests, which I called a piazza, chattering in their low, soft voices, and imagined the mother birds and babies must enjoy the pleasant sound. The Swallow family is very interesting. The Cliff Swallow, Wood Swallow, Chimney Swallow, Sand Martin and Purple Martin are all cousins, having some of the same characteristics."

When "Artist" had finished reading his sketch, the selections were given, Miss Sweet beginning with the

\section{SWALLOW SONG.}

BY ANNA BOYNTON AVERILI.

$O$, to feel the wild thrill of the Swallow,

The wonder of the wing,

On the soft blue billows of air to follow

The summer and soar and sing! 
To drink blue air and to feel it flowing Through every dainty plume, Uplifting, pillowing, bearing, blowing, And the earth below in bloom.

Is it far to heaven, O Swallow, Swallow?

The heavy-hearted sings;

I watch thy flight and I long to follow

The while I wait for wings.

\section{THE SWALLOW.}

BY OWEN MEREDITH.

O Swallow, chirping in the sparkling eaves, Why hast thou left far south thy fairy homes, To build between these drenched April leaves, And sing me songs of Spring before it comes?

Too soon thou singest! Yon black stubborn thorn, Bursts not a bud; the sneaping wind drifts on. She that once flung thee crumbs and in the morn Sang from the lattice where thou sings't is gone. Here is no Spring. Thy flight yet further follow. Fly off, vain Swallow!

Thou com'st to mock me with remembered things, I love thee not, $O$ bird for me too gay, That which I want thou hast,- - the gift of wings;

Grief-which I have--thou hast not. Fly away! 
What hath my roof for thee? My cold, dark roof,

Beneath whose weeping thatch thine eggs will freeze!

Summer will halt not here, so keep aloof.

Others are gone; go thou. In those wet trees

I see no Spring, though thou still singest of it.

Fare hence, false prophet!

\section{A BIRD AT SUNSET.}

BY OWEN MEREDITH.

Wild bird, that wingest wide the glimmering moors,

Whither, by belts of yellowing woods, away?

With pausing sunset thy wild heart allures

Deep into dying day?

Would that my heart on wings like thine, could pass

Where stars their light in rosy regions lose,-

A happy shadow o'er the warm brown grass,

Falling with falling dews!

Hast thou, like me, some true love of thine own,

In fairy lands beyond the utmost seas;

Who there, unsolaced, yearns for thee alone,

And sings to silent trees?

O tell that woodbird that the summer grieves,

And the suns darken and the days grow cold;

And tell her, love will fade with fading leaves,

And cease in common mould.

Fly from the winter of the world to her!

Fly, happy bird! I follow in thy flight, 'Till thou art lost o'er yonder fringe of fir

In baths of crimson light.

* $*$ * * * * * * * * *


Miss Sweet wrote upon the blackboard Thompson's description of their nest building.

The Swallow sweeps

The slimy pool, to build its hanging house Intent. And often from the careless back

Of herds and flocks, a thousand tugging bills

Pluck hair and wool; and oft, when unobserved, Steal from the barn a straw; till soft and warm, Clean and complete their habitation grows.

\section{QUESTIONS.}

Do Swallows ever build in trees?

In what other places than a barn do they build?

What enables them to fly so swiftly?

How many kinds of Swallows do you know?

How do they obtain their food?

For what trait are the Swallows most noted, for their song, their beauty, the swiftness of their flight, the gracefulness of their motions, or their ingenuity at nest building?

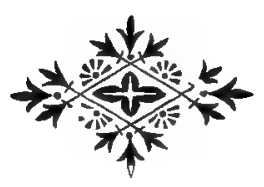




\section{WOOD PEWEE.}

\section{(Contopus i'i'rens.)}

(9) LIVACEOUS brown, darker on head. Sides, paler. Under parts, whitish, tinged with dull yellow. Tail and wings, blackish; wings somewhat marked with white. Feet and upper mandible, black. Under mandible, yellow. Length, 6 to $6 \frac{1}{2}$ inches. Bill, very flat. Wings, long and pointed. Tail, but little shorter than wing.

Eastern North America in woodlands. Nest, a pretty structure saddled on a horizontal bough, of fine fibers stuck over with lichens, the whole looking like an excrescence of the tree.

Eggs, four to five, creamy white, marked with reddish brown and lilac,

Has a drawling note, pe a wee a pe wee.

"Every morning," said Miss Sweet, "I have intended to speak again about the 'tables.' I have sometimes thought that when you have copied them in your note books, you consider your work with them is done, while really they are the most inportant part of our lessons, since they contain accurate information, and if you study them carefully you will be able to know every bird described. There is a great difference of opinion about the Pewee, some writers consider him interesting, while others think him quarrelsome and his iteration of 'pee-ee-wee-ee' positively tiresome."

"Auntie says," said Laura, "that the Pewee is about the only bird that she cannot endure. She says he sits in the shade and laments just like some folks, 
who shut all sunshine out of their lives and then go around complaining and expecting folks to pity them. She thinks he has little to recommend him in any way, as he quarrels with his relatives and neighbors and is not even good-looking or graceful."

"She is rather hard on the poor little bird," said the boy who had been the first to compare birds to people. "I know he is a sad-looking bird with drooping wings and tail, but if you sit and watch this forlorn little fellow and listen to his doleful song, you will be surprised to see him rouse up suddenly and perform his remarkable gyrations. When a fly comes nearWhizz! he goes after it, turns a somerset, catches it, and is back again in a second. I think he is very interesting."

"I can hardly tell the Pewee, the Phœbe and the Chickadee apart," said one of the girls.

"Even the poets sometimes mistake them," replied Miss Sweet. “The Pewee's song is more drawling and sad than that of the Phœbe; while the Chickadee's is more lively than either, and contains more notes. Of the three, the Chickadee is the most sociable and fearless."

"I like to hear them after all the other birds are still," said Laura, "it makes me think of the 'Amen' at the close of an anthem."

"Do they always come at the same time in the spring, Miss Sweet?" asked "Querist."

"No! there is a great variation in their time of 
arrival, but they seem to know when to come. That is the mystery that Laura wrote about in her essay on the 'Migration of Birds.' Still, it sometimes happens that a cold rain sets in after their arrival, and, unless they find shelter many of them perish, for their feathers are not oily or close enough to be a protection in bad weather.

"The nest of the Pewee is beautiful" said "Student." $\mathrm{He}$ is a good Architect, if he is not a poet or very loveable.

After all, this bird seems to be quite interesting although he is not a very great favorite with the poets, said "Baby." I will recite some lines by John $T$. 'Trowbridge about the

\section{PEWEE.}

For so I found my forest bird,

The Pewee of the loneliest woods

Sole singer in these solitudes,

Which never Robin's whistle stirred,

Where never Bluebird's plume intrudes.

Quick darting through the dewy morn, The Redstart trilled its twittering horn, And vanished in thick boughs; at even Like liquid pearls fresh showered from Heaven The high hotes of the lone Wood Thrush

Fall on the forests lonely hush;

But thou all day complainest here

Pewee! pewee! pe-ere! 


\section{QUESTIONS.}

Where is the Pewee's favorite home?

What are its habits as to food and nest building?

In how many ways may we distinguish the Pewee from the Phobe (Pewit) or the Chickadee?

Why cannot the Phobe and the Pewee winter in the north as well as the Chickadee?

Which of the three is your favorite?

Why?

Have the poets written much about the Pewee?

What kind of a nest does this bird build?

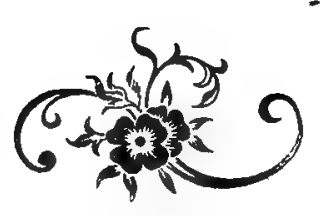




\section{THE BOBOLINK.}

(Dolicho'nyx oryzi'vorus.)

(1) Bebolink or Meadow-Wink is 7 to $7 \frac{1}{2}$ inches long. Claws, long and feet strong for walking or clinging to weeds. Plumage of male, black, white and buff from May to August, when it changes to something like that of the female, a yellowish brown. Female smaller than male.

Tail feathers, stiff and acute. Found in eastern United States and Canada. Breeds in June and July, after which they collect in large flocks and migrate.

Their food in the early summer consists of insects entirely. In the middle states they are called "reed birds," in the South "rice birds" and in the West Indies, where they winter, they are called butter-birds.

They nest on the ground. Eggs, four to six, a slate gray, spotted and mottled with dark brown. They migrate at night.

"You see by Laura's table," said Miss Sweet, "that our present lesson begins with the Bobolink. I have written down the names of birds that you see on the blackboard, which I desire you to copy into your note books. I cannot emphasize too frequently the use of the 'tables' in your future study. I hope when school opens next fall that you will have taken many notes, from observation, on the habits of birds, their food, and their homes, for which you will have ample opportunity, even though you do not spend the vacation in the country." 

Bobolink.

Cowbird.

Catbird.

Humming Bird.
Kingbird.

Oriole.

Thrush.

Veery.

"Does the Bobolink really travel in the night?" quickly asked "Querist."

"Yes," replied Miss Sweet. "John Burroughs says he has awakened in the middle of the night and heard their faint notes as they were passing over the city of Washington on their return from the north."

"I used to hear him often in Massachusetts," said Laura, "but I seldom hear him here. We children used to call him the 'jolly rover,' because he never seemed to be quiet, and his song had a rollicking sound, as though he was full of fun. I have often heard him just after sunrise, and, indeed, at all hours of the day, for he seems to like to sing when folks are around to hear him."

"He is a beautiful bird in spring and summer," said "Artist." "It seems strange that he should lose his pretty coat in autumn. I have seen him hovering over the nest wheré his mate was sitting, and sing as though he could not express his joy. He was like a beautiful vision of happiness. I have often found his nest on the ground, in the meadow at my grandfather's, and have watched him for hours."

"We didn't use to think much of him in the south," remarked a girl who had only recently come north to live. "Everybody thought he was a great 
pest, as he destroys millions of dollars' worth of rice every year. On his way north he eats the freshly planted seed, and when he returns in autumn he feasts on the matured crop."

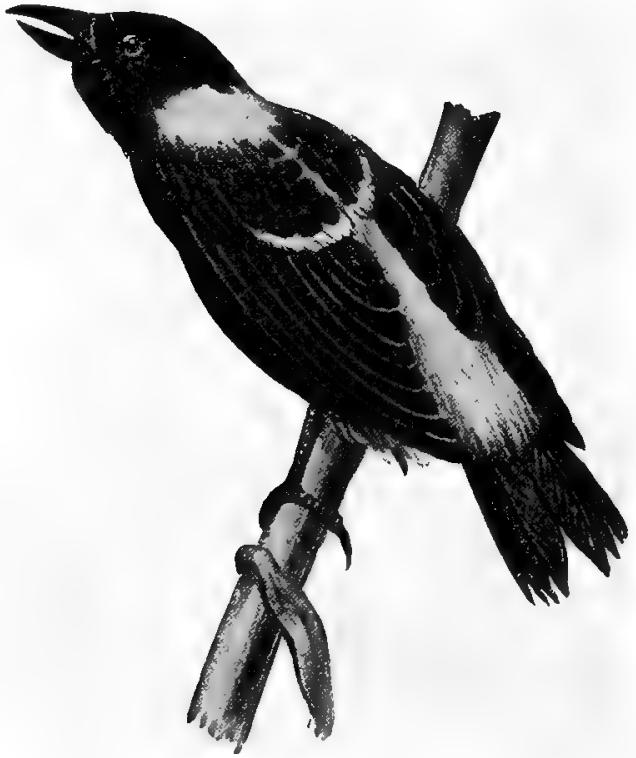

BOBOLINK.

[ONE-HALF LIFE SIZE.]

"Isn't it strange that he should seem almost like a robber in one part of the country and more like a poet in another?" asked "Querist."

"Yes," replied the southern girl. "It is hard for me to realize the qualities ascribed to the Bobolink." 
OUR FRIENDS, THE BIRDS.

"He is a great favorite with us in the north," said Miss Sweet, "and the poets have written many pretty things about him. I will recite Lorenzo D. Gillespie's verses on the
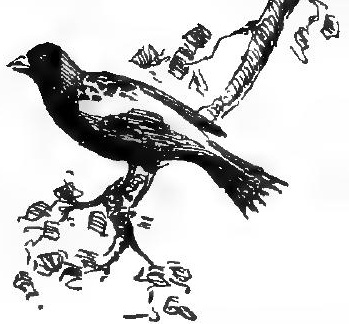

\section{BOBOLINK.}

When the summer leaves were green

And the shrubbery cast a shade,

Where the richest flowers were seen

And the gayest birds that played.

As I walked along and mused,

Oft I paused to catch this note

Pouring from his tiny throat-

Sping, spang, spink,

Bobolink, Bobolink.

Those were balmy days of youth

When no trouble crossed my mind;

Then my garnished shield was truth,

And my thoughts were all sublime;

But like youth those days are past,

And no voice has ever sung

As that did when Bobbie sang-

Sping, spang, spink,

Bobolink, Bobolink.

The pupils were so delighted with this that they again forgot they were in school and applauded her heartily. When quiet was restored, they recited in concert the following lines by Thomas Hill: 
Gayest songster of the spring !

Thy melodies before me bring

Visions of some dream-built land

Where, by constant zephyrs fanned,

I might walk the livelong day,

Embosomed in perpetual May.

Nor care nor fear thy bosom knows,

For thee a tempest never blows;

But when our northern summer's o'er,

By Delaware or Schtylkill's shore

The wild rice lifts its airy head, And royal feasts for thee are spread.

And when the winter threatens there,

Thy tireless wings yet own no fear,

But bear thee to more southern coasts,

Far beyond the reach of frosts.

Bobolink! still may thy gladness

Take from the all taints of sadness.

"Student" said: "James Russell Lowell was a great lover of this bird. He said:

"Why, I'd give more for one live Bobolink

Than a square mile o' larks in printer's ink."

"My mother," she continued. "called my attention to these beautiful lines by him:

June's bridesman, poet o' the year,

Gladness on wings, the Bobolink is here;

Half-hid in tip-top apple bloom he sings,

Or climbs against the breeze with quiverin' wings,

Or, givin' way to 't in mock despair,

Runs down a brook o' laughter, thro' the air. 


\section{QUESTIONS.}

Is the Bobolink always jolly?

Have you ever heard him sing?

At what time of the year does he sing?

How long does he wear his bright coat?

Where do they build their nests?

How are they treated in the northern states?

How in the southern?

What does Bryant say of "Robert of Lincoln's Quaker wife"?

Have you read The O'Lincoln Family, by Wilson Flagg?

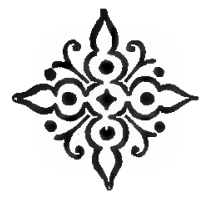




\section{COWBIRD.}

\section{(Milothrus a'ter.)}

USTROUS green black with steel blue, purple and violet

(9) iridescence. Head and neck, deep wood brown with some purple lustre; bill and feet, black; length, $7 \mathrm{I} / 2$ to 8 inches.

Female, a dusky grayish brown with slight greenish lustre on upper parts; young, duller brown.

North America; migratory, abundant, gregarious, parasitic.

It builds no nest, but lays its eggs in the nests of other birds smaller than itself. The eggs hatch sooner than other eggs and so crowd out the rightful owner of the nest. Usually one egg in a nest; sometimes more. White, speckled with brown.

Miss Sweet had asked one of the girls to write about this bird, and now asked her to read her essay, which was entitled:

\section{A BLACKBIRD'S COUSIN.}

Cowbirds are not, in themselves, an interesting class, but they have furnished a theme for many entertaining bird stories and lengthy descriptions of their peculiar habits.

The only attractive thing about them is their unlikeness to all other birds. They have no beant-, no song, no nest; and seem to be of little importance co the world except to eat a few insects and noxious seeds. Captain Bendire, in "Life Histories of American Birds," says: "Their food is chiefly small grains and the seeds of ragweed, smartweed, and fox-tail grass. Taking its 
food alone into consideration it does perhaps more good than harm."

They, without doubt, destroy many insect-eating birds by crowding them out of the nest or taking the food from them and starving them while they are quite young.

Birds resort to various methods to rid themselves of the strange egg or eggs when they find them in their nests. As the eggs are usually laid in the nests of small birds, they have no way of getting them out without breaking them and spoiling the nest. Some birds desert the nest, others build a second nest over the egg, while many sit upon them, hatch them and watch over and care for them as tenderly as their own.

No poet has ever written a line in honor of the Cowbird, in fact, little can be said in their favor. They are the outcasts of bird society.

I have read an amusing story somewhere of a Cowbird stealing away from the flock and depositing an egg in the newly made nest of a Catbird. The Catbird is not so often victimized as some of our smaller birds; but this time, seeing a new nest unguarded, Mrs. Cowbird quietly took possession. When the Catbird returned and found an egg in her nest, she looked about for the intruder of her new domicile. Seeing an innocent Sparrow near by she flew furiously at him and gave him a severe trouncing. Then, with the help of her mate she succeeded in removing the strange egg from her nest. 
The Cowbird is one of the smaller Blackbird's, and so I suppose is a cousin to the Purple Grackle. Even the Bobolink and Meadowlark belong to the same family, although, I should think they would be ashamed of their bad and disagreeable relative.

\section{QUESTIONS.}

Why are not Cowbirds interesting?

Why have not the poets written about this bird?

Why do they not rear their own young?

Do you consider them selfish birds, seeking only their own pleasure and crowding out their better neighbors?

How are they regarded by other birds?

What other birds belong to the same family?

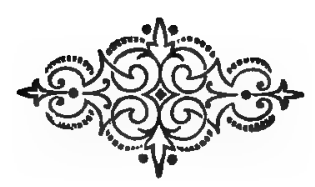




\section{THE CATBIRD}

(Mimus carolinen'sis)

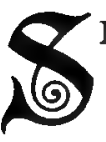

LATE GRAY, paler below. Crown of head, bill and feet, black. Quills of wings, blackish. Length, 8 to 9 inches. Young of a more sooty color. United States and British Provinces, west to Rocky Mountains. Migratory, but resident in southern states.

Nest of sticks, leaves, and bark in bushes or low trees.

Eggs, four to six, deep greenish blue, not spotted.

Remarkable for its harsh cry like the mewing of a cat, but also possessed of eminent vocal ability, like others of the Thrush family.

An abundant and familiar inhabitant of our groves and briery tracts.

Miss Sweet was surprised to find that one of the boys, who had seemed to take little interest in the lessons, had prepared without solicitation a little sketch about

\section{- THE CATBIRD.}

These birds are very trim, neat and Quakerlike in appearance, but not in action. They delight in hearing themselves sing and in being heard. They are merry and lively, singing not only their own song, but often trying the songs of other birds. It is said that they can deceive the Quail, the Pewee and the Chewink by an imitation of their notes. The catlike sound they make, from which they get their name, is the 
only unpleasant feature of the Catbirds. To atone for this harsh note they have a low "whisper song" about the nest, that is remarkably sweet and musical. Whether it is the mother-bird's lullaby song, or her mate's household words of love, in minor keys, is not known.

I have read about the Catbird in several books on birds, and I find that authorities differ concerning his character. John B. Grant, in his little book on "Our Common Birds, and How to Know Them," says, "The bird is really a handsome one, but, owing to its skulking habits, and the unsocial manner in which it resents inspection, scarcely a favorite;" while William Everett Cram, in "Bird Land Echoes" says, "Do one thing well and perfection is expected in all directions, yet who among men and which of the birds has ever reached this high degree? The Catbird has reasons for not singing in August, and for what we interpret as complaining instead. It is none of our business. We are wholly unreasonable. There is enough sweetness in the May-day orchard song of the bird to remain with us a delightful recollection until May-day comes again, and for this we should be thankful." It seems to me that few people ever remember, either in birds or children, the pleasant words and actions, when for any reason they appear peevish and unreasonable.

The Catbird occasionally stays all winter, although he usually goes south, returning in early May. Its cat-like cry is sometimes tiresome, but, from my own observation, I consider him a very interesting bird 
and easily tamed. He has a bad name, and is said to destroy the eggs of other birds. His food is similar to a Robin's, and opinion is divided as to whether he helps the farmer by destroying insects or hinders him by stealing fruit. My own opinion is, that, like some mischievous boys, he has acquired a bad name through his love of fun, and desire to have a good time.

Leander S. Keyser, in his "In Birdland," gives an amusing incident of a Catbird singing with "a bit of paper in its bill, which gave to its tones a peculiar resonance. $\mathrm{He}$ was one of the choicest minstrels of Birdland I have ever heard, his voice being of excellent timbre, his tones pure and liquid, and his execution almost perfect."

The Wren and the Thrasher, who are also noted vocalists, are his cousins. His song sometimes resembles the Red Thrush, but the Catbird has some notes that will distinguish it from the song of this bird.

The essay excited a good deal of discussion. Afterward Miss Sweet recited

\section{A RAIN SONG.}

BY CLINTON SCOLLARD.

After long days of golden glare,

How sweet the music of the rain?

And how ecstatic on the air

The Catbird's silvery strain! 
I see him in his cloistered gown, This tuneful eremite in gray, Swaying in rapture up and down On yon althea spray?

His passionate runs and tremolos, Transcend the clearest notes of art, As doth the peerless summer rose Its winter counterpart.

His throat seems thrilled with lyric fire, And listening there thrills me through A touch of that divine desire The elder poets knew.

My soul would search the secret springs Where life's supremest meanings throng, Would set sublime celestial things To chords of earthly song,

A sudden mellow change, and lo! The impulse, like a ray, is gone, As from the clouds the vermeil glow At the full burst of dawn.

Yet who shall say such sounds are sent

Unto the spirit sense in vain?

Did it not hide some large intent,

That bird song in the rain? 


\section{QUESTIONS.}

Have you heard the Catbird's "Whisper Song" ?

To what birds is he related?

In what way is he useful to man?

What other bird songs resemble his?

Does he migrate?

When does he sing his sweetest song?

Which is your favorite, the Robin or Catbird?

Can you tell some amusing tricks of the Catbird?

Have the poets said much about him? Why?

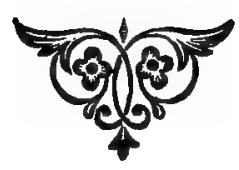




\title{
HUMMING BIRDS.
}

\author{
(Trochilida.)
}

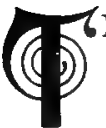

HESE beautiful little creatures will be known at sight. Their flying apparatus is like that of the swifts. Feet, extremely small and weak, unfit for progression and formed exclusively for perching.

The bill is long and extremely slender for its length; it is usually straight, subulate or awl-shaped, or with lancet-shaped tip; it is often decurved, sometimes recurved, and again bent at almost an angle; in length it varies from less than the head to more than all the rest of the bird.

The Hummers are the least of all birds, the giants among them reaching a length of 6 or 7 inches; the pigmies being under 3 inches; the usual stature is 3 or 4 inches.

In a few the color is plain, or even sombre; most have glittering iridescent tints.

The structure of the tongue somewhat resembles that of Woodpeckers, capable of being thrust far out of the beak. The tongue is, in effect, a double-barreled tube, supposed to be used to suck the sweets of flowers.

The food of the Hummers was formerly supposed to be the sweets of flowers. It is now known that they are chiefly insectivorous.

Their nests are models of architectural beauty. The eggs are always two in number.

The young hatch weak and helpless. The voice is not musical. The Hummers are peculiar to America.

Laura embodied in the table so much information 
that nothing else was attempted, as there was little

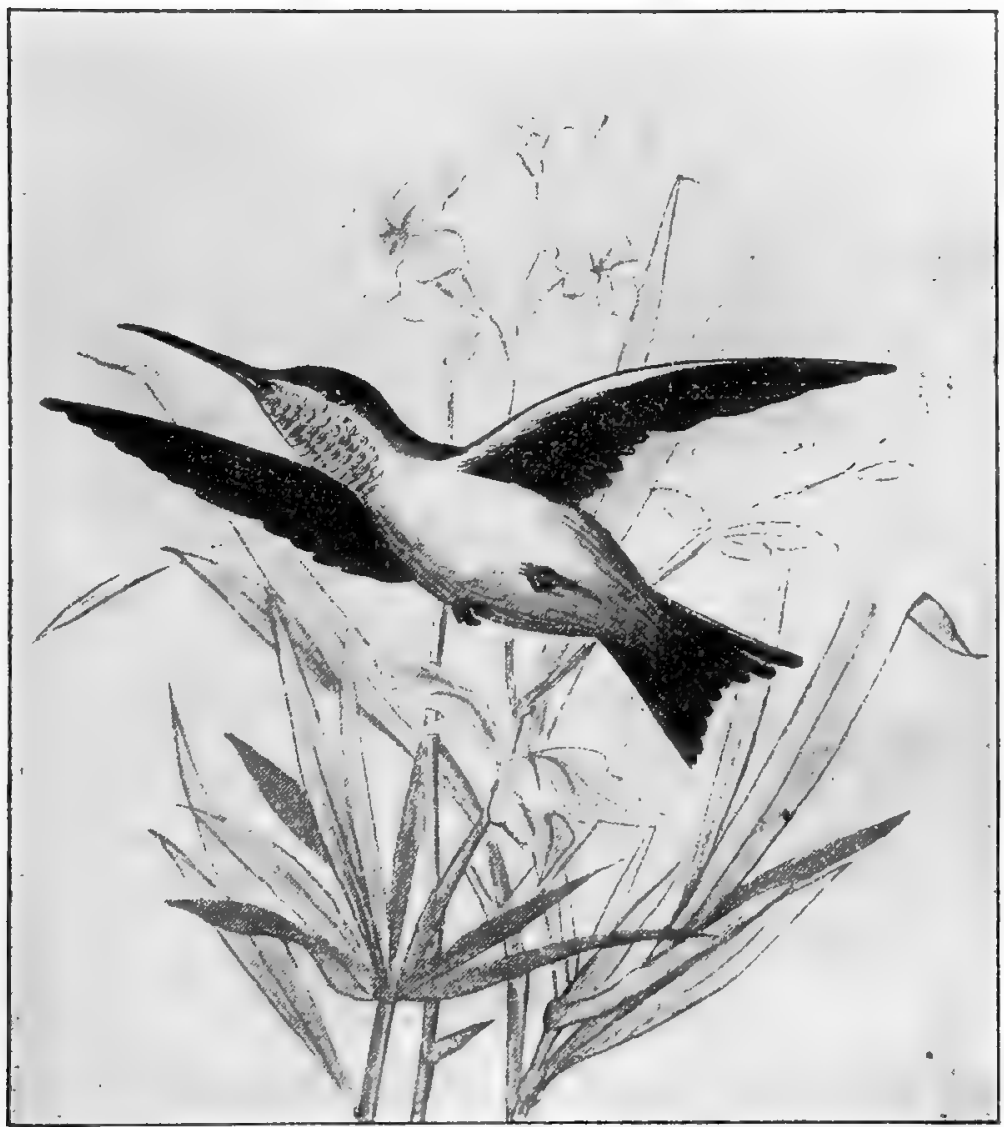

HUMMING BIRD.

[ONE-HALF LIFE SIZE.]

time this morning for the lesson. The following poem was read: 


\section{THE HUMMING BIRD.}

BY JOHN B. KAYE.

Rare little bird of the bower!

Bird of the musical wing

While hiding thy head in some flower

Softly thy green pinions sing.

Sing like the harp of Atolus,

Hum out each murmuring note

With a charm having power to control um

As we watch thee suspended, afloat.

Hid from the dull sight of mortals,

Out of the reach of the bee

Down through the lily's white portals

Nectar's distilling for thee.

Now at the thistle's red tassel

Probing with needle-like bill.

Drinking a sweet, dreamy wassail.

Humming thy melody still.

Where the wild honey-bee hover:

In the perfume-laden air,

Whither stray light-hearted lovers,

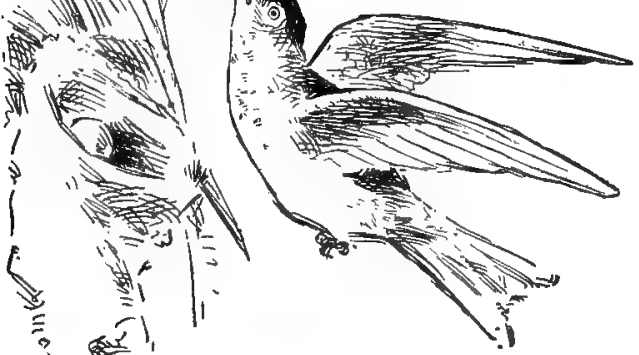

Often they meet with thed there.

Always thou dwellest 'mid beauty

Bird of melodious wing, Toseek it's thy life's only duty. And bask in perpetual spring. 
OUR FRIENDS, THE BIRDS.

\section{QUESTIONS.}

How many different kinds of Hummir g Birds have you seen?

How many are in the United States?

How many species altogether?

If their range is "from Alaska to Patagonia" where do you think the greatest number is always found?

Where are the most beautiful ones found?

Of what do they build their nests? 


\section{THE KINGBIRD. BEE-MARTIN.}

(Tyrannus carolinen'sis.)

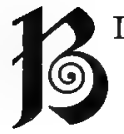

LACKISH-ASH; darker or black on head, crown with a flaming spot; below, pure white; breast, shaded with light ash; wings, dusky with much white edging; tail black, broadly and sharply tipped with white; tail, even or slightly rounded; length, about 8 inches; eastern United States to Rocky Mountains; abundant in summer; winters on southern border.

Nest, in orchards or by the wayside on a horizontal bough, cupped and compactly woven; eggs, four to six, white, rosy or creamy, spotted with reddish or darker brown; shell markings, lilac. Irritable, pugnacious and intrepid. Destroys thousands of noxious insects.

Miss Sweet, as has been suggested, was always on the look-out for new ideas; so when she found one boy was interested enough to study and write, she called for another volunteer. The Humming Bird was quickly passed on account of lack of time, but a lesson on the Kingbird was prepared by the quietest boy in the class, known as "Mouse."

\section{THE KINGBIRD.}

The Bee-Martin, as he is familiarly called, is a rather dull looking bird almost as large as a Robin. The flaming spot in his crest is not easily seen, but we know him by the white band at the end of his tail 
He will sit for a long time on some exposed branch, pluming himself or simply waiting for something to eat. He does not fly around in the business-like way of other birds after his food, but waits quietly for the insects to come to him. Sometimes he merely opens his mouth when he sees a fly coming. Sometimes he darts after it, but returns to his perch. $\mathrm{He}$ is active enough when pursuing some other bird.

$\mathrm{He}$ is no singer but makes a twittering noise as he flies. His human enemy is the bee-keeper who thinks that the sole business of the "Bee-Martin," as he calls him, is to destroy his bees. It is said that he prefers the drones but sometimes snaps up the queen bee while she is out on the single journey of her life. Many writers have described his wonderful courage in attacking birds larger than himself and coming off the victor in the fight. Many have testified to his usefulness in ridding the world of insect pests; but the poets have found nothing about him to invoke the Muse.

Ernest Ingersoll in his "Country Cousins" relates an incident which shows that his kingship is not equal to all emergencies. He says: "Between the showers one of these royal fellows came over the field with a self-confident swing in his flight, and alighted on a sapling. He had stood there not a minute, when up sprang two Wrens from their perch on the highest beam of the bridge, and dashed at him like little furies. The surprise and impetuosity of that attack was too much for him, and though he had more than once 
driven the mighty Eagle to find safety in the clouds, yet these little tormentors upset his courage and he fled as fast as his wings could carry him."

\section{QUESTIONS.}

Have you seen an example of the Kingbird's fighting powers?

Do you think he shows courage or merely a wish to torment other birds?

Does he always choose birds "of his size?"

What interesting thing have you observed or read about him?

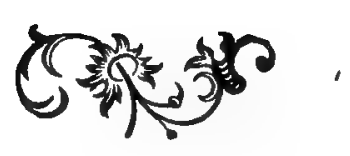




\section{BALTIMORE ORIOLE.}

(Ic'terus gal'bula.)

$\mathbb{N}^{\mathrm{A}}$ AMED from the title of Sir George Calvert, first Baron of Baltimore, whose colors were orange and black. Head, neck and back, black; wings, black, edged and tipped with white; middle tail coverts, black; other tail and all other parts, fiery orange; bill and feet, blue black; length, 7.50 to 8 inches.

Female, smaller and paler, more olive than black; nest, a deftly woven fabric, hanging in the very tops of shade trees; eggs, four to six, shaded white, spotted and scrawled with blackish brown, and other heavy markings.

One of our most beautiful birds, as well as a fine and constant singer during the breeding season. United States and British Provinces. Migratory.

Another boy volunteered the following information concerning

\section{THE ORIOLE.}

This bird has a diversity of gifts. He is not only one of the most brilliant in plumage, and has one of the brightest songs, but he claims a place in the front rank of nest builders. His custom is to weave a purselike nest, from three to six inches deep, fastened high up to slender swaying twigs; but he has been known to make a shallow basket-shaped nest on the top of a horizontal limb. Such a nest he builds lower, among the leaves. 
There is a little English book on birds that makes this statement: "The Baltimore Oriole lives in Baltimore in North America. It builds a hanging nest about three feet long and one foot across." Where would the poor little Orioles be in a nest like that?

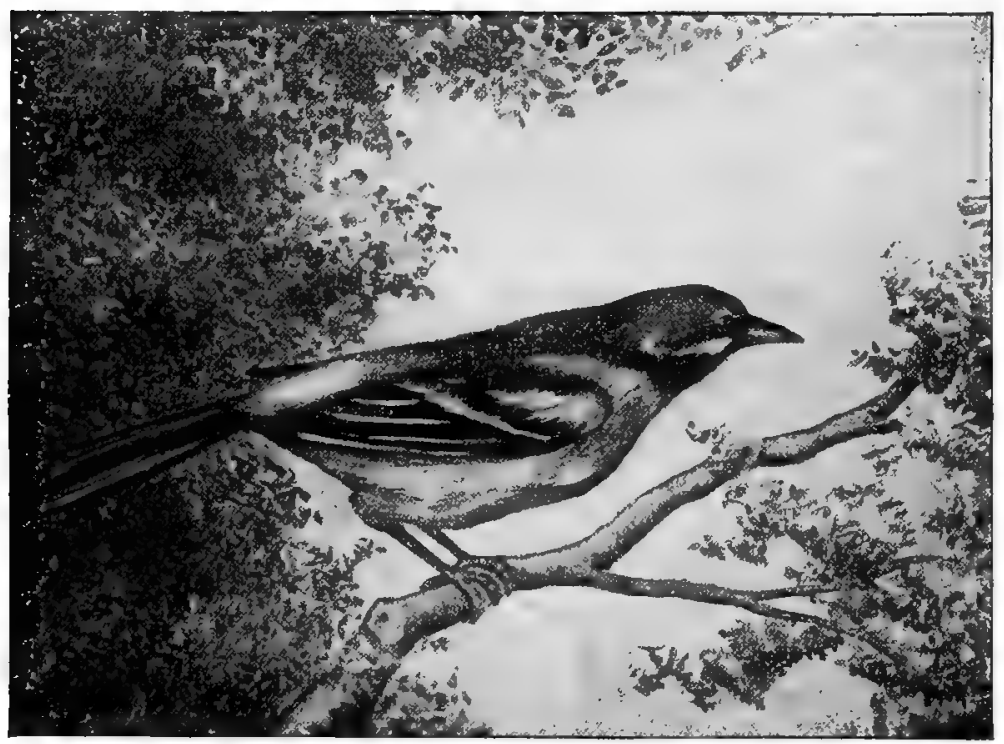

BALTIMORE ORIOLE.

[ONE-HALF LIFE-SIZE.]

Some people object to the Oriole's shrill whistle, while others praise it extravagantly. It probably depends upon when and where it is heard.

John Burroughs, in "Wake Robin," gives a very interesting account of the Baltimore Oriole. This was 
of more interest to me than anything else that I have read, that it is possible for an ordinary reader to get hold of.

The "Golden Robin" is said by some writers to destroy fruit blossoms, but others say that they destroy larvæ which infest the blossoms. This seems most probable, as its food consist of insects.

The squirrel is an enemy to this bird, and destroys its eggs. Its nest is very curious and it uses all kinds of thread-like materials. It is a beautiful and unusually interesting bird.

Edgar Fawcett describes this bird in the following beautiful lines:

How falls it, Oriole, thou hast come to fly

In tropic splendor through our northern sky?

At some glad moment was it nature's choice

To dower a scrap of sunset with a voice?

Or did some orange tulip flaked with black

In some forgotten garden, ages back,

Yearning toward Heaven until its wish was heard

Desire unspeakably to be a bird?

"Another charming poem," said Miss Sweet is

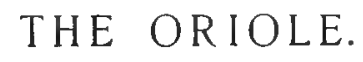

BY JAMES RUSSELL LOWELL.

Hush! 'Tis he!

My Oriole, my glance of summer fire

Is come at last, and, ever on the watch,

Twitches the pack-thread I had lightly wound

About the bough to help his housekeeping,- 
Twitches and scouts by turns, blessing his luck:

Yet fearing me who laid it in his way,

Nor, more than wiser we in our affairs,

Divines the providence that hides and helps.

Heave, ho! Heave, ho! he whistles as the twine

Slackens its hold; once more, now! and a flash

Lightens across the sunlight to the elm

Where his mate dangles at her cup of felt.

Nor all his booty is the thread; he trails

My loosened thought with it along the air,

And I must follow, would I ever find

The inward rhyme to all this wealth of life.

QUESTIONS.

Who are the Oriole's enemies?

What material does he use in building?

Is the female as brilliant in color as the male?

How long does the Oriole sing?

What is his food and how does he get it?

Does he prefer to build near dwellings or in the wood?

Does he build the same kind of nest in all situations?

Have you read anything about the Oriole by John Burroughs? 


\section{WOOD THRUSH.}

(Turdus musteli'nus.)

PPER parts tawny brown, purest and deepest on the head, shading to olivaceous on the tail. Below, pure white, faintly tinged on the breast with buff. Much marked with rounded or subtriangular blackish spots. Under wing coverts, mostly white. Bill, blackish brown with flesh-colored or yellowish base. Feet, yellowish or flesh-colored. Length, 71/2 to 8 inches. Extent about 13 inches. Eastern United States to New England. Migratory. A famous vocalist, common in low, damp woods and thickets.

Nest in low trees or bushes, of mud, leaves, and grasses. Eggs, four to six, plain greenish blue like those of the Robin, but smaller. Breeds throughout its range.

"Baby" wrote the following description of the

\section{WOOD THRUSH:}

"This bird is a cousin to the Robin, but he far excels him in the richness of his song. He is not so sociable a bird, but prefers to have his home in the silent groves. Longfellow says:

" "And where the shadows deepest fell,

The Wood Thrush rang his silver bell.'

"So if we are not content with Robin's 'Be cheery, Be cheery,' we must seek in solitudes this 'silver bell.' It seems strange that when they so often build far from any dwelling, they always use a bit of paper in the foundation of the nest. 
"H. L. Graham says: 'I believe there would be a greater number of Thrushes nesting in our gardens, were it not for the quarrelsome English Sparrows and the large number of cruel, ignorant men and boys.'"

Miss Sweet said, "Much more might be said about this little bird, but our selections will supplement our information."

\section{THE THRUSH.}

BY LUCY H. WASHINGTON.

Beautiful, beautiful forest bird,

Dost thou tarry to sing unto me?

Gladly thy clear woodland voice is heard

Trilling so wild and free.

* * * * *

Alas, thou hast flown far away, far away,

Still my heart will remember thee long;

Remember at parting thou seem'dst to say,

Gather fragments of sunshine and song.

Richard Edwin Day is the author of the following verses:

So near, sweet bird, thou art

With breast and ear,

To nature's lips and tranquil heart

Her thought is always clear

What we who stray from her apew.

Are loth and late to hea- 
OUR FRIENDS, 'THE' BIRDS.

Still from its placid spring

That note of might

Thou heedest not what voice may sing

Victorious delight

Raptures must pass; the abiding thing

Is clear and peaceful sight.

The following verse by Edmund Burke was recited in concert:

Each bird gives o'er his note, the Thrush alone Fills the cool grove when all the rest are gone.

Harmonious bird! daring till night to stay, And glean the last remainder of the day.

QUESTIONS.

Name some cousins of the Wood Thrush.

Do they all build similar nests?

How does the Robin's nest differ?

How does the Veery's differ from either?

Have you ever heard the evening song of the Thrush?

Where may we find his home?

What does he eat?

What have you read about him? 


\section{WILSON'S THRUSH. VEERY.}

\section{(Turdus fusces'cens.)}

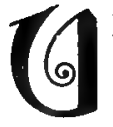

PPER PARTS, reddish brown, with slight olive shade; quills and tail feathers, darker brown; no light ring around the eye; under parts, white; sides, shaded with gray or grayish olive; throat, buff colored; breast, white, marked with a few small brown arrow heads; bill, dark above, pale below like the feet. Length, 7.25 to 7.50. Female, smaller. Eastern United States to Canada. Migratory; nesting in northern part of range. Nest, on ground or near it, of leaves, grasses, but no mud. Eiggs, four to five, greenish blue.

A delightful songster. Found in thick woods and swamps, of shy and retiring habits.

Miss Sweet said, "This bird is not familiar to city folks. If you will take your 'table' with you and study his habits during your summer vacation, you will have an interesting story to tell on your return.

"On account of the Veery's habit of building its nest in the north only, its song is not so familiar to many as that of the Wood Thrush. In some parts of its range it may be seen only during migrations. Bird lovers differ greatly in their estimate of the song of the Veery.

"Wilson Flagg says, 'His song, though loud for so small a bird, is modulated with such a sweet and flowing cadence that it comes to the ear like a strain from some elfin source.' He also quotes from Mr. 
Ridgway: "There was a solemn harmony and a beautiful expression which combined to make the song of this bird surpass that of all the other American Thrushes.' Burroughs says, 'Wood Thrush and Hermit stand at the head as songsters.'

"The birds which we have been studying are those that arrive early in May or late in April. Our next list will also contain some birds that arrive early in May, as the greater number of our birds do.

"If you will copy the following names of birds we will be all ready for our next lesson.

Cardinal Grosbeak

Indigo Bird.

Whippoorwill.

Scarlet Tanager.

Oven-bird.

"Instead of the usual scientific 'table,' Laura will give us an original sketch of the Cardinal, in our next lesson." 


\section{THE CARDINAL GROSBEAK.}

(Cardinalis virginia'nus.)

(QD) Cardinal or Redbird as he is commonly called
is so fumiliar to all that he needs but little de-
scription. He has been so much used as a cagebird that many who have never seen the "flash of flame" in his "green retreat" have made his acquaintance behind the wires. He is beautiful even there, but can never give the delight that he does when his bright coat flits beside his dusky mate amid the dark green of a glossy oak.

Once, while traveling in the country, I stopped for a few minutes at a house where a Redbird's cage hung in the porch. The bird crept about slowly on his perch, and acted very like an old man who had lost much of his interest in life. Although he was plump and well-fed he had a faded appearance, only the tips of his feathers were red.

I asked the woman what caused him to look so. She replied that he was growing gray, for he had been in the cage more than twenty years. She said that when she and her brothers were children her mother often came to their rooms in the morning and said, "Don't you hear Reddy? He says, "Get-up get-up get up'!"

"We always thought that that was his morning song. My brothers have gone to other homes and 
Reddy was left to me. Now he calls to my little girl, here, as he did to me in the mornings twenty

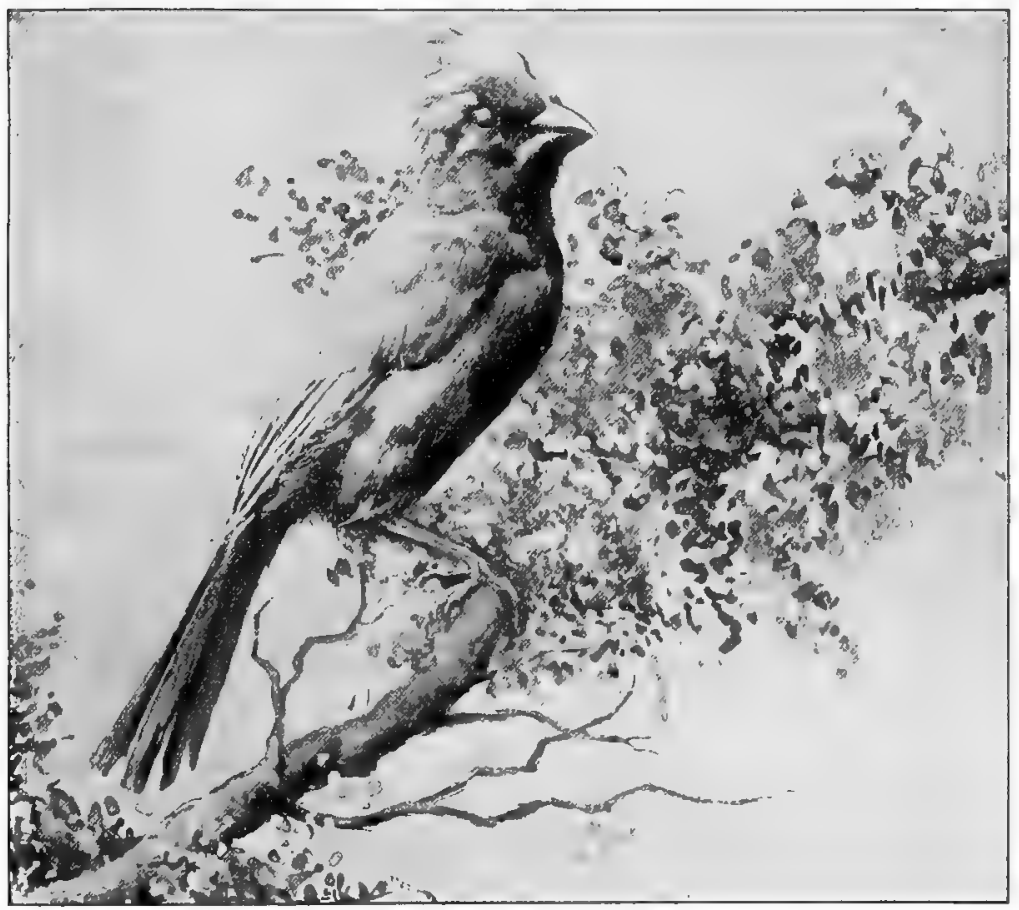

CARDINAL.

[ONE-HALF LIFE SIZE.]

years ago, 'Get up-get up-get up.' But his coat is not 
so bright, and his voice is not so cheery as they were in those days when I was a child."

Dr. Coues says of the Cardinal Grosbeak: "A bird of striking appearance and brilliant vocal powers, resident and abundant from the Middle States southward; inhabits thickets, tangle and undergrowth of all kinds, whence issue its rich, rolling, whistling notes, while the performer, brightly clad as he is, often eludes observation by his shyness, vigilance and activity."

H. E. Parkhurst says in the "Bird's Calendar," "The Cardinal is brilliant, stately, unsocial, and apparently not anxious to make the most of his gifts. Can any one say that birds are not types of mankind?"

The Rose-breasted Grosbeak is another beautiful bird belonging to the same family, but it is rarely seeu by the ordinary observer.

\section{QUESTIONS.}

What other beautiful bird belongs to the samefamily? Compare the Cardinal with the Scarlet Tanager. Which is more beautiful?

Where is the winter home of the Cardinal?

At what time of year have you first seen him? What interesting incident can you tell about him? What do you think he says?

Is he a social bird?

Why does he not make the most of his talents? Is he a singer? 


\section{INDIGO-BIRD.}

(Passeri'na cya'nea.)

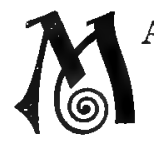

$A L E$, indigo-blue, intense and constant on the head, glancing greenish on other parts with different lights; wings and tail, blackish, glossed with greenish blue; bill, dark above, paler below. Female, plain warm brown above, rather paler below; wing coverts and inner quills, pale edged, but not whitish; upper mandible, blackish; lower, pale, with a black stripe. Eastern United States to Maine and Canada; west, to Kansas and Indian Territory.

Nest in the crotch of a bush, large for the size of the bird, and not at all artistic. Eiggs, four to five, white, with a faint blue shade; sometimes a little speckled.

"The Indigo-bird is not so well known as our friend in sky-blue that comes with the earliest zephyrs of Spring," said "Artist." "His coat is so dark a blue that in the sunlight it sometimes looks green."

"Querist" asked: "Did you ever see an Indigobird, Miss Sweet?"

"Yes; I was seated, one morning, in a favorite spot for bird study, on the side of a hill, above a gently flowing stream. On the opposite bank stood a dead tree, and beyond it spread a smooth, open level space of ground, with a few bushes here and there, and some driftwood scattered about.

"On a limb of the dead tree, in good range for my 
opera glass, stood our fighting friend, the Kingbird. I watched him for some time standing, just standing

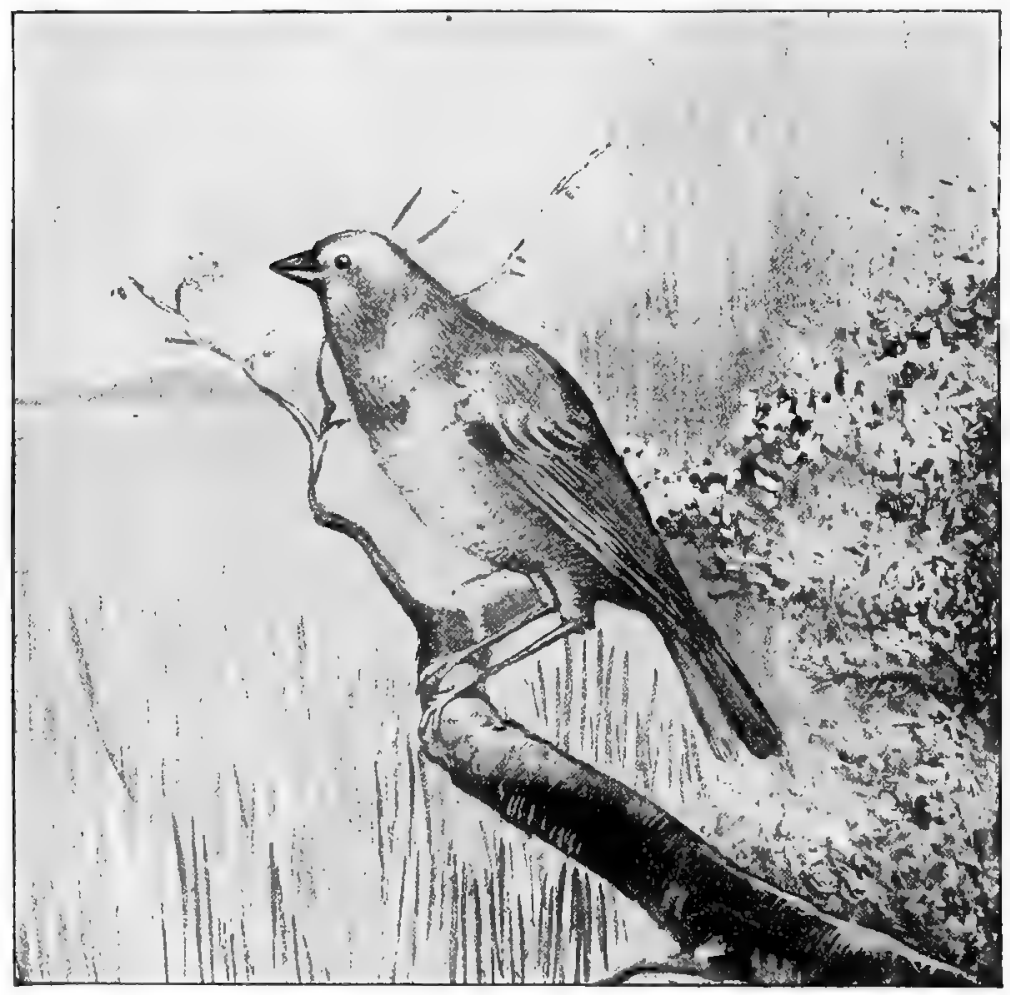

INDIGO-BIRD.

[THREE-FOURTHS LIFE SIZE.]

there, and occasionally opening his mouth so wide that I had a good view of his red throat. At first I laughed, thinking he was yawning; but I soon discovered he was 
only opening the door to admit an unwary gnat that was passing by.

"While he was amusing me by his lazy way of getting a breakfast, from out a clump of bushes, over the creek, came a bevy of Indigo-birds. They floated and danced, and whirled and sang. It was such a soft, joyous, sweet, little 'laughlike' song as they chased each other merrily over the grass and among the bushes.

"They seemed to be having a merry little game of some kind. Or were they taking a lesson in flight and music? I could not tell. At any rate it must have been a happy lesson.

"Since that, whenever I hear our little friend in indigo-blue, it brings up a picture of that bright June morning with its bright blue sky, of the hill by the creek, of the Kingbird on the tree, the rustic footbridge spanning the stream and the grand old forest of oaks stretching far away to the southward, and recalls the delightful sensation of being alone with Nature, and listening to one of her sweetest melodies. Such pictures form one of the most delightful features of bird study. I have a poem in the 'Youth's Companion' by Ethelwyn Wetherald delightfully descriptive of 


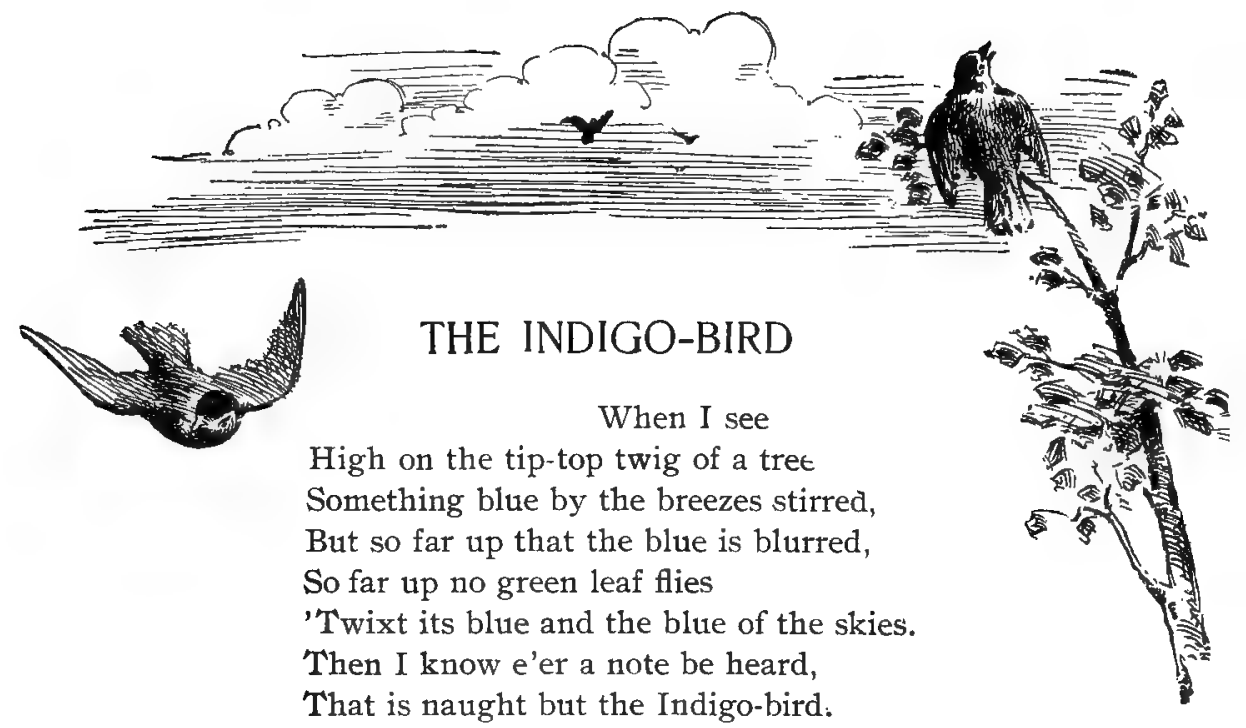

3lue on the branch and blue in the sky, and naught between but the breezes high, And naught so blue by the breezes stirred As the deep, deep blue of the Indigo-bird.

\section{When I hear}

A song like a bird laugh blithe and clear, As though some airy jest he had heard, The last and the most delightful word, A laugh as fresh in the Angust haze As it was in the full voiced April days, Then I know that my heart is stirred By the laughlike song of the Indigo-bird.

Joy on the branch, and joy in the sky, And naught between but the breezes high, And naught so glad on the breezes heard As the gay, gay note of the Indigo-bird. 
OUR FRIENDS, THE BIRDS.

QUESTIONS.

Have you ever heard "the laughlike song of the Indigo-bird"?

Do you think the fore-going poem a true picture of the bird and its song?

How does it differ from the Bluebird of Spring?

Which is your favorite?

Which is more common?

What is the favorite haunt of the Indigo-bird?

Is his nest artistic?

Where does he build it?

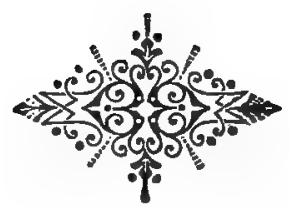




\section{SCARLET TANAGER.}

\section{(Pyran'garu'bra.)}

(Q) OLOR of male, crimson or scarlet; wings and tail, black; bill and feet, dark horn color. Fiemale, clear olive green above; below, clear greenish yellow; wings and tail, dusky. Male is said to change to color of the female in the fall. Length 6 to 7 inches.

Eastern United States, British Provinces, west to Kansas and Indian Territory. Not common north of Massachusetts.

This brilliant creature nests in woods, groves and orchards, upon the horizontal limb of a tree; building a rather loose nest of twigs, ifibers, rootlets, etc. Eggs, three to five, dull greenish blue, fully spotted with brown and lilac. Voice not musical.

"Artist" had a beautiful specimen of the Scarlet Tanager which had been given him by a friend who is a taxidermist. The children were greatly interested in it.

"I never saw a live one," said he, "for the Tanager prefers the deep woods for his home, and so his beautiful plumage is seldom seen. My friend told me that the sight of him is like the discovery of a rare and brilliant flower. He is even brighter than the Cardinal Grosbeak, but has not his beauty of song. His one gift is the gift of fine feathers.

"There is probably no greater contrast between the male and female of any species of birds than that between the Tanagers. One could scarcely believe the 
bird in olive green and yellow to be the mate of one in

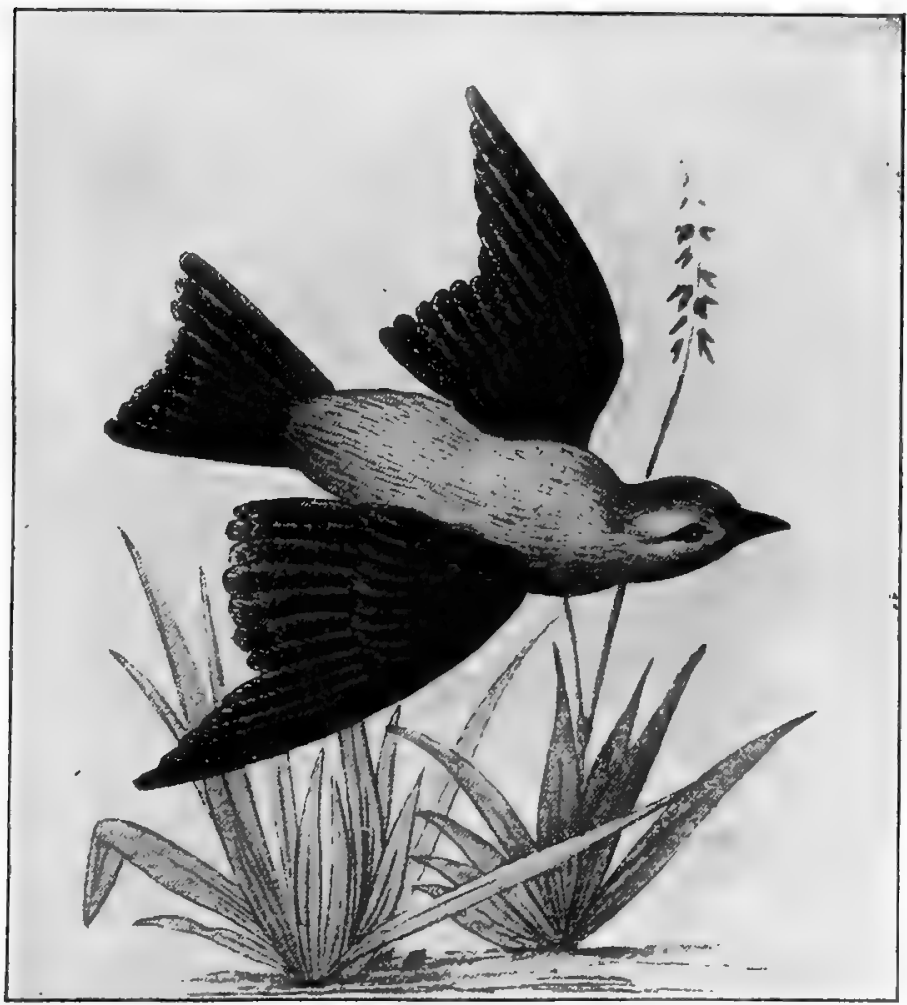

TANAGER.

[ONE-HALF LITE SIZE.]

scarlet and black. Longfellow may have thought of the Tanagers when he wrote: 
The softly warbled song

Comes through the pleasant woods, and colored wings Are glancing in the golden sun, along

The forest openings.

Miss Sweet said: "The birds who inspire the poets are not those of brilliant plumage, but those of sweetest song. I read a verse the other day about bird language that is very sweet:

One language the birds have, one.

They use it by day, they use it by night They use it in shadow and sun.

'Tis the language of love, the same, the same, Wherever its harmony grows.

"A great favorite of mine is a poem about bird songs, entitled:

\section{IN SUMMER TIME.}

BY SIDNEY DAYRE.

"Chickety wee kewee kewee" -

That was the sound that came to me;

"Riddledee ree and fiddlede f $f$ "-

Some in the trees and some in the sky.

"IVillicum wink" and "rinkety rink"

Now, pray, will you tell me what you think

All those birds could have meant to say

As I walked out in the woods today.

Ah! such music you never heard-

But you couldn't have told a single word. 
They kept it up, a "kikeri coo,"

A " chickamaree cahoo cahoo,"

A "filli cafum" and "willi cawee"

Now what could it ever, ever be

Those saucy, rollicking, frolicking birds

Were trying to tell without the words.

I've often wondered if it might be A message of cheer to you and me, Twittered and trilled as best they could;

"The world is happy and God is good."

QUESTIONS.

Have you ever seen a Scarlet Tanager?

Where?

Is he a good nest builder?

What is his song like?

Is he as large as the Cardinal ?

Can you think why he stays in the deep woods?

Have any poets written about the Tanager?

If so, what? 


\section{THE WHIPPOORWILL.}

Caprimul'gus vocif'erus.

PPER PARTS variegated with grey, black, whitish and tawny; prevailing tone, grey; black streaks on head and back; the colors elsewhere, delicately marbled. Wings and their coverts with bars of rufous spots. Lateral tail feathers, black, with white or tawny terminal spaces. White or tawny throat-bar. White specks continue around neck from throat-bar. Elastic bristles about the bill. Length, 9 to 10 inches. Eastern United States and British Provinces. Migratory. No nest; two eggs, on log or stump; creamy white, heaviiy marked with brown. Eggs and young sometimes removed it the parent's mouth. Habits, nocturnal. Perches, lengthwise.

"When I was a little girl," said Miss Sweet, "I lived in a country village. Back of our house were some cultivated fields, and beyond those the woods. Every night, as soon as it began to be dark, I would listen for the Whippoorwill, and, as soon as he began to call, my mother would say 'Come, now, the Whippoorwill is calling his babies. Probably he wants to put them to bed before he begins his night work.' 'Does he whip them ?' I would ask. She always said she didn't know, but she told me many things about the bird, so my thoughts of him are always associated with bed-time stories. Although I have heard and known his voice ever since I can remember, I never saw one outside of a museum." 
"It seems to me the Whippoorwill is a good deal like a hermit," said Laura, "he is so retiring in his habits, and likes to dwell in solitude. He even seeks his food at night, and skulks among the dead leaves in daytime."

"I have often looked for him," said "Artist," "but he is not easily found on account of resting lengthwise on the limb which hides him from observers below."

"Why do people have a superstitious feeling of dread on hearing the notes of the Whippoorwill?" asked "Querist."

"He shares, with all other nightbirds, the reputation of being a bird of ill-omen," replied Miss Sweet. "This is not so much the fault of the birds as it is of the strange phases of the human mind. The morning hopefulness and strength accord with the singing birds of dawn, but night's weariness and disappointment weigh us down until every sound is a sound of woe. The notes of the Quail and the Whippoorwill are almost the same, yet the Quail is considered a cheerful fellow."

"We always think of him as associated with the first hours of darkness," said "Student," "but, in looking for poetry concerning him, I found one entitled: 


\section{DAWN.}

BY SAMUEL M. PECK,

The Summer night is turning gray;

A prescience warms the eastern way, And o'er the fountain's silver spray

Lets fall a rosy light.

Upon a distant pine-clad hill

The shadow haunting Whippoorwill

Laments the night with plaintive trill

And spreads his wing for flight.

"I suppose he is associated in our minds with the early hours of darkness because we are not usually awake later. Cowper says:

Ten thousand warblers cheer the day

And one the live-long night.

\section{"And Isaac McClellan, Jr., says:}

Lone Whippoorwill!

There is much sweetness in thy fitful hymn,

Heard in the drowsy watches of the night.

"Alonzo Lewis sings of all the night birds in his poem entitled:

\section{NIGHT BIRDS.}

High overhead the striped-winged night hawk soars

With loud responses to his distant love;

And while the air for insects he explores,

In frequent swoop descending from above,

Startles, with whizzing sound, the fearful wight,

Who wanders lonely in the silent night. 
Around our heads, the bat, on leathern wings,

In airy circles wheels his sudden flight;

The Whippoorwill, in distant forests, sings

Her loud, unvaried song; and o'er the night

The boding Owl upon the evening gale,

Sends forth her wild and melancholy wail.

The first sweet hour of gentle evening flies,

On downy pinions to eternal rest;

Along the vale the balmy breezes rise,

Fanning the languid boughs; while in the west

The last faint streaks of daylight die away,

And night and silence close the summer day.

QUESTIONS.

In what way does the Whippoorwill differ from other birds?

What other bird is much like the Whippoorwill?

At what time of day might we find one?

Have you ever seen one? If so, tell all about it.

What have you read about the Whippoorwill?

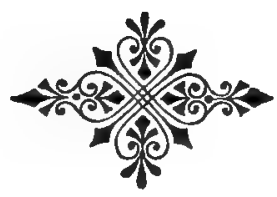




\section{OVEN BIRD. GOLDEN-CROWNED THRUSH.}

(Seiu'rus auricapil'lus.)

NTIRE upper parts including wings and tail, uniform
bright olive green. Top of head, with black lateral
stripes bounding a golden brown or dull orange space. A white ring round eye. Under parts, white, thickly spotted with dusky on the breast, the spots lengthening into stripes on the sides. Under wing coverts tinged with yellow. Legs, fleshcolored. Length 5.75 to 6.50 . Varies much in size. Sexes indistinguishable.

North America to Colorado, Dakota and Alaska.

Called "Oven Bird" from the way it has of roofing over its nest.

Ëggs, four to six, white or creamy, speckled with reddishbrown and lilac.

"I object to the name Oven Bird. It is too common for a bird," said "Baby."

"It has other names," replied another pupil. "It is called Golden-crowned Thrush, Golden-crowned Accentor, Golden-crowned Wagtail and Warbler. You know it belongs to the large family of Wood Warblers."

"Did you ever see one?" asked "Querist."

"I saw one once," said "Artist," "when I was at my grandfather's. I was lying flat on the ground in a fence corner, enjoying the varieties of color, when I saw a pert little bird walk along almost in front of me. It made me think of my little sister when she puts on 
some of my mother's clothes and assumes a yieat deal dignity, so I laughed and it dodged out of sight. I had a good look at it, though, and I asked my grandfather what kind of a bird it was. He told me about its nest, too, and I spent a good deal of time hunting for one, and at last with his help I was lucky enough to discover one.

"It was built of fibrous roots and grass and its arched roof resembles, in shape, the old Dutch oven. It looked so much like the surrounding grass and leaves that it is no wonder I couldn't find it easily."

"You were more fortunate than auntie and I were," said Laura. "One summer we heard the cheeping of a young one somewhere about the foot of a vine-covered oak. The tree stood on the side of a gently sloping hill, and about its roots ran the vines of wild ivy. The mother bird flew to the branches above, with a short warning cry. The young one was quiet. No amount of search, morning after morning, was rewarded with a sight of the nest. The mother bird kept up a continual scolding in the tree, but never went to the nest while we were near. Auntie said she liked to see children mind, but she objected to such strict discipline in a bird."

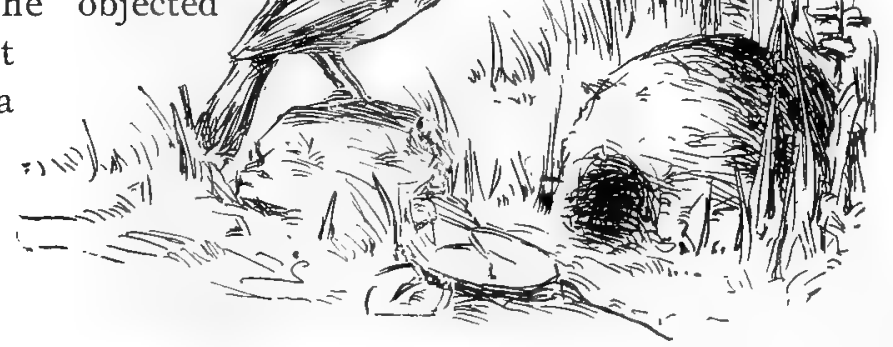


"Is it much of a singer?" questioned "Querist." "I can best answer that," replied the teacher, "by quoting what Ernest E. Thompson says' in St. Nicholas, "The Oven Bird, at.certain seasons of the year, rises into the air, far above the tops of the forest trees, and as he floats on quivering wing pours forth a loud, sweet, lark-like song-a song full of variety and tenderness and so prolonged and powerful that one wonders if indeed so small a throat can really be the source of that volume of sweet sound."

"Do you know who 'Bolles' is, Miss Sweet?" asked the usual questioner. "I found a poem by him on

\section{THE OVEN BIRD.}

In the hollows of the mountains,

In the valley spreading from them,

Stand the rustling broad-leaved forests

Trees whose leaves are shed in autumn.

Underneath them lie the leaf beds, Resting one upon another,

Laid there yearly by the storm winds;

Pressed and smoothed by winter snowdrifts.

In the days of spring migrations,

Days when warbler hosts move northward

To the forests, to the leaf beds,

Comes the tiny oven builder.

Daintily the leaves he tiptoes;

Underneath them builds his oven, Arched and framed with last year's oak leaves, Roofed and walled against the raindrops. 


$$
\text { QUESTIONS. }
$$

Does the Oven Bird hop or walk?

To what family does it belong?

How many names has this bird?

Which name is prettiest?

Why has it so many names?

Where would you seek its nest?

Have you ever found one?

Does this bird sing most at morning, noon or evening?

Of what other poem does the one given above remind you? 


\section{SANDPIPER. WILSON'S STINT.}

Actodro'mas minutil'la.

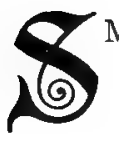

MALLEST of the Sandpipers. Length, 5.50 to 6 inches. Bill, black; legs, dusky greenish. Upper parts, each feather blackish centrally and edged with bright bay, and tipped with ashy or white; quills, blackish; tail feathers, gray, with whitish edges, the central ones blackish with reddish edges; whitish line orer eye.

North and South America and West Indies. Breeds in high latitudes. Returns to United States in August. Very abundant curing its migrations. Eggs, unknown.

"The Sandpiper always makes me think of an old maid," said the little southern girl. "They go teetering along as though they were afraid they would not be thought modest enough. I used to see them often on the river bank at home."

"I have seen them on the seashore in summer," said Laura. "They are odd-looking little creatures, and I believe they do appear a little prim, though I never thought of it before."

"Perhaps they have to be careful how they walk because their legs are so long," said another girl.

"Did you ever notice what a long bill they have?" asked "Querist."

"I really do not know much about them," said Miss Sweet. "I never saw one, and have never had any books to which I had access that gave me any satisfactory information. Perhaps, if we keep our eyes 
open, we may get acquainted with at least one variety during our vacation. I certainly shall try to, as Laura's 'table' has whetted my curiosity. I will read a poem that I like very much."

\section{THE SANDPIPER.}

BY CELI TEAXXRR.

Across the narrow beach we flit

One little Sandpiper and I, And fast I gather, bit by bit,

The scattered driftwood bleached and dry.

The wild waves reach their hands for it,

The wild wind raves, the tide runs high,

As up and down the beach we flit,

One little Sandpiper and I.

Above our heads the sullen clouds

Scud black and swift across the sky.

Like silent ghosts in misty shrouds

Stand out the white lighthouses high.

Almost as far as eye can reach

I see the close-reefed vessels fly

As fast we flit along the beach

One little Sandpiper and I.

I watch him as he skims along

Uttering his sweet and mournful cry.

He starts not at my fitful song,

Or flash of fluttering.drapery;

$\mathrm{He}$ has no thought of any wrong;

He scans me with a fearless eye;

Stanch friends are we, well-tried and strong,

The little Sandpiper and I. 
Comrade, where wilt thou be to-night

When the loosed storm breaks furiously?

My driftwood fire will burn so bright

To what warm shelter can'st thou fly?

I do not fear for thee, though wroth

The tempest rushes through the sky;

For ate not we God's children both,

Thou, little Sandpiper and I?

\section{QUESTIONS.}

\section{Have you ever seen a Sandpiper?}

Where should we go to look for Sandpipers?

Have you seen any other birds that looked some. thing like the Sandpiper?

Do you think the Woodcock is a cousin to the Sandpiper?

Did you ever see the Woodcock carry its little ones away in its feet?

What is the food of the Sandpiper?

Are there any larger Sandpipers than Wilson's Stint?

Can you repeat the last stanza of Celia Thaxter's poem?

In whose writings may we find these lines:

"Tripping light as a Sandpiper over the beach,

Swerving this way and that.as the wave of the moment

Washes out its slight trace with a dash of whim's foam on't." 


\section{EAGLE. BIRD OF PREY.}

(Haliatus leucoceph'alus.)

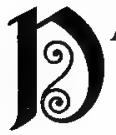

ARK brown; quills, black; head and tail, white; bill, eyes, and feet, yellow. Length, about 3 feet; extent, 6 to 7 feet. Wing, 2 feet or less; tail, a foot or more. Three years are required for the perfection of the white head and tail of the "bald" eagle. The first year the young are black eagles; very dark colored, with fleecy white bases of the feathers showing here and there; bill, black; iris, brown; feet, yellow. The next year they are "gray" eagles and usually larger than the old birds, the largest known specimens being of this kind. North America anywhere. A piratical parasite of the Osprey. Famous as the emblem of the Republic.

"My father was in the regiment that the Eagle belonged to," said a bright girl, who had not before contributed any information. "I have written down what he told me about

\section{"OLD ABE."}

During the Civil war a regiment of United States soldiers had a pet Eagle that they called "Old Abe." When they were in camp, he remained with them, sharing their rations and going about as it pleased him; but when they went into battle, the big bird was there in the midst of it, perched upon a banner, screaming and flapping his wings as if to urge them on. Six times he 


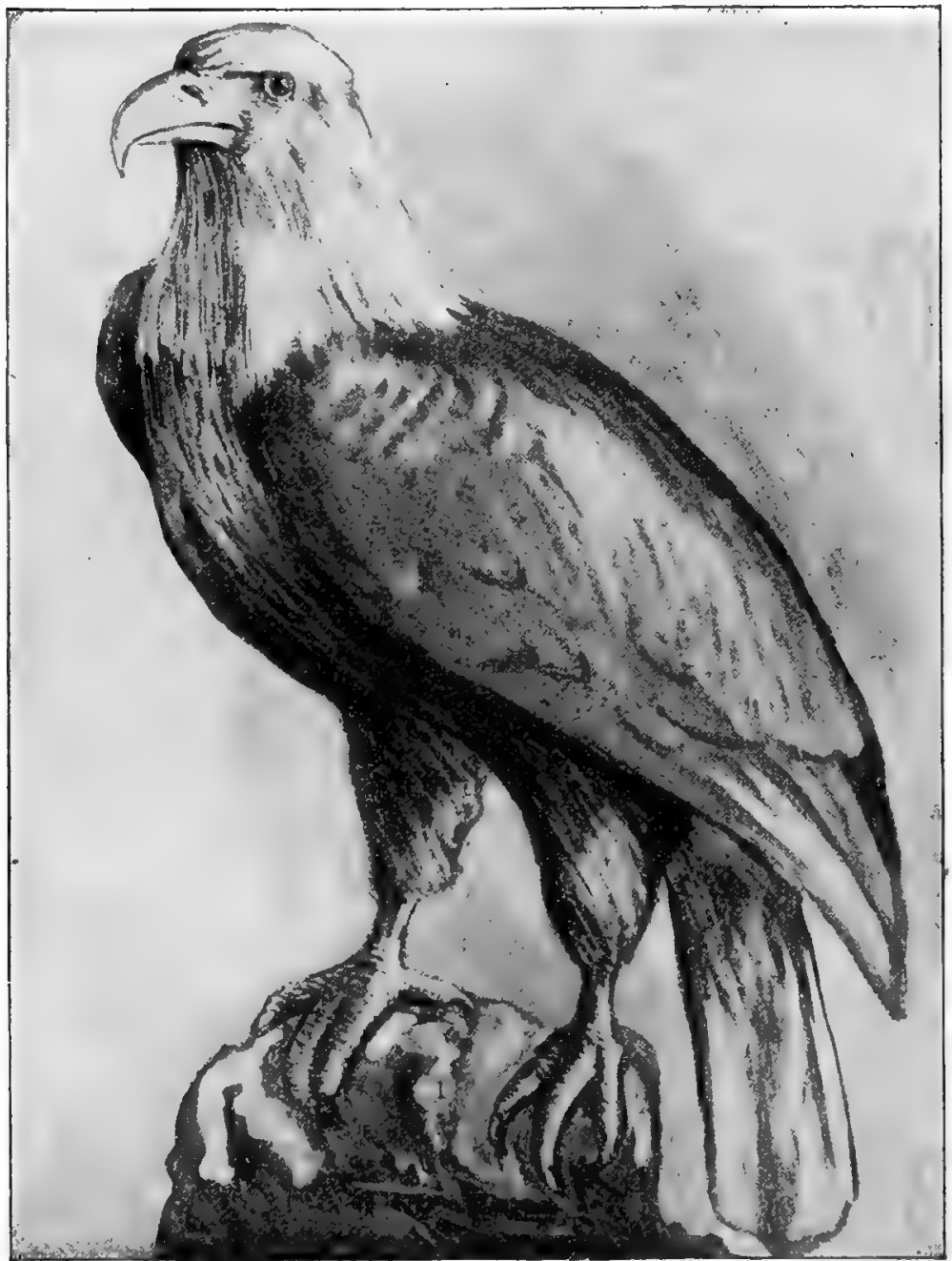

EAGLE.

LONE-EIGITH LIFE SIZE.] 
was wounded by the flying bullets, but he never deserted his post.

Eleven years after the close of the war, he was taken to the Centennial Exposition at Philadelphia in charge of one of the members of the old regiment. Soon after that he died.

"I saw 'Old Abe' once," said a boy, "but he didn't look very interesting. He just sat still and looked fierce."

"When I was a very little girl," said Laura, "my father went hunting one day with a friend, along the banks of the Milwaukee river. I have asked him to tell me about it so often, I have a picture in my mind of the place. There were bushes and trees along the bank of the river, so that they could not be seen approaching, nor could they see the water. They came, at last, to a bayou or perhaps a branch of the river, and as they reached this intersection they were surprised to see four or five large Eagles fly off from a rock in the river. "There was no time for consultation and they fired simultaneously. One of the Eagles fell into the water, and as there was a strong wind blowing it floated to the opposite side of the bayou. This was crossed by a railroad bridge a little farther down, so my father went over and by taking considerable trouble, fished the Eagle out. He took it to a taxidermist and when it was mounted gave it to my mother. It has always stood on top of one of the book cases ever since I can remember. I used to be afraid of it, but now, if it 
should be taken away, I should feel as though one of the family had gone."

"The Eagle is familiar to all of us in one way or another," said Miss Sweet, "as it is well known in picture and story, but in its wild state it comes and goes like a visitor.

"Benjamin Franklin said of the Eagle: 'For my part I wish the Bald Eagle had not been chosen as the representation of our country. He is a bird of bad moral character; he does not get his living honestly. You may have seen him perched upon some dead tree, where, too lazy to fish for himself, he watches the labors of the Fishing-hawk, and when the diligent bird has at length taken a fish and is bearing it away to his nest for the support of his mate and young ones, the Bald Eagle pursues him and takes it from him. **** He is, therefore, by no means a proper emblem for the brave and honest Cincinnati of America, who has driven out all the Kingbirds of our country.'

"Yet the Eagle has had his admirers among the poets who, no doubt, overlook his deficiencies of character in their admiration of his grand size and wonderful powers of flight and dignified appearance."

\section{THE EAGLE. \\ BY JAMES G. PERCIVAL.}

Thou art perched aloft on the beetling crag,

And the waves are white below, And on, with a haste that cannot lag

They rush in an endless flow. 
Again thou hast plumed thy wing for flight

To lands beyond the sea,

And. away, like a spirit bathed in light,

Thou hurriest wild and free.

I ord of the boundless realm of air,

In thy imperial name,

The heart of the bold and ardent dare

The dangerous path of fame.

Beneath the shade of thy golden wings

The Roman legions bore

From the river of Egypt's cloudy springs,

Their pride, to the polar shore.

As this was the last lesson before the summer vacation, no questions had been prepared.

The pupils were delighted with the acquaintances they had made among the birds, and separated with the promise of a more intimate friendship with some of them before school should open again in the fall. 




